
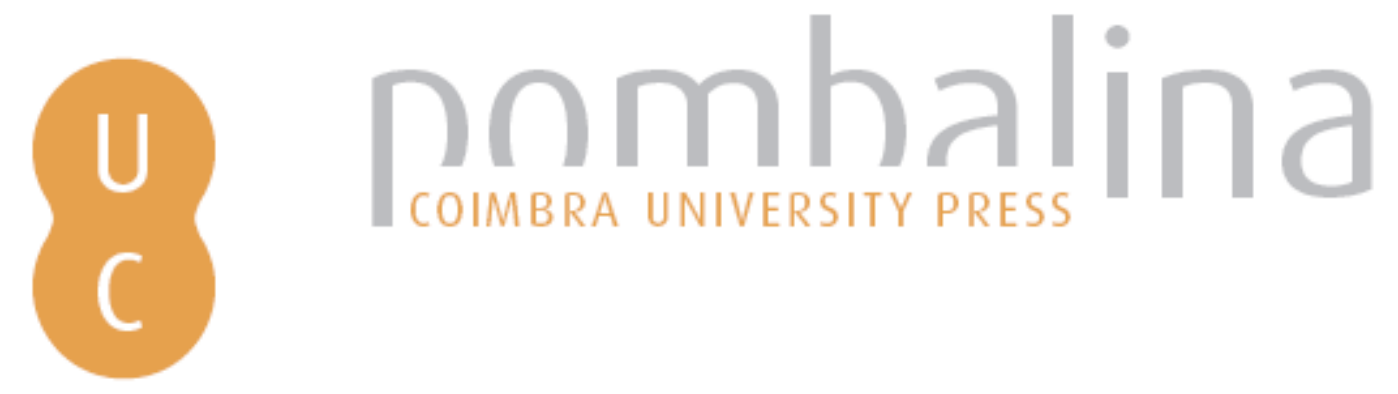

\title{
Reflexões sobre a Liberdade: 150 anos da obra de John Stuart Mill
}

Autor(es): $\quad$ Peixinho, Ana Teresa, coord.; Camponez, Carlos, coord.

Publicado por: Imprensa da Universidade de Coimbra

URL

persistente:

http://hdl.handle.net/10316.2/2737

DOI:

http://dx.doi.org/10.14195/978-989-26-0204-2

Accessed : $\quad$ 19-Nov-2014 16:10:39

A navegação consulta e descarregamento dos títulos inseridos nas Bibliotecas Digitais UC Digitalis, UC Pombalina e UC Impactum, pressupõem a aceitação plena e sem reservas dos Termos e Condições de Uso destas Bibliotecas Digitais, disponíveis em https://digitalis.uc.pt/pt-pt/termos.

Conforme exposto nos referidos Termos e Condições de Uso, o descarregamento de títulos de acesso restrito requer uma licença válida de autorização devendo o utilizador aceder ao(s) documento(s) a partir de um endereço de IP da instituição detentora da supramencionada licença.

Ao utilizador é apenas permitido o descarregamento para uso pessoal, pelo que o emprego do(s) título(s) descarregado(s) para outro fim, designadamente comercial, carece de autorização do respetivo autor ou editor da obra.

Na medida em que todas as obras da UC Digitalis se encontram protegidas pelo Código do Direito de Autor e Direitos Conexos e demais legislação aplicável, toda a cópia, parcial ou total, deste documento, nos casos em que é legalmente admitida, deverá conter ou fazer-se acompanhar por este aviso. 


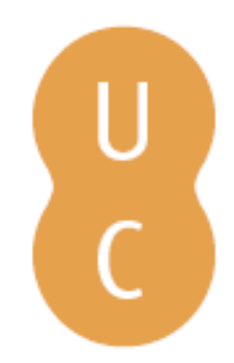

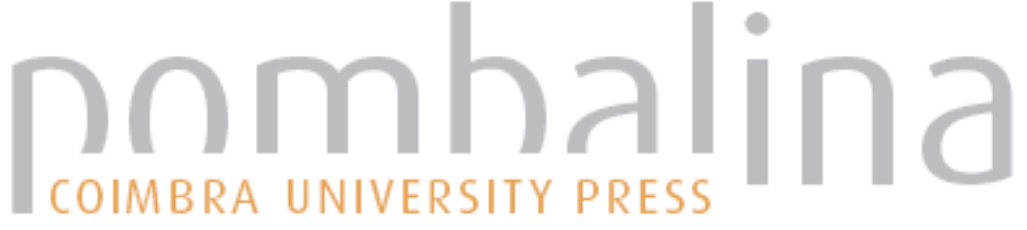

\section{Reflexões sobre a Liberdade: 150 anos da obra de John Stuart Mill}

Autor(es): $\quad$ Peixinho, Ana Teresa, coord.; Camponez, Carlos, coord.

Publicado por: Imprensa da Universidade de Coimbra

URL

persistente: URI:http://hdl.handle.net/10316.2/2737

DOI: $\quad$ DOI:http://dx.doi.org/10.14195/978-989-26-0204-2

Accessed : $\quad$ 13-Nov-2014 12:21:38

A navegação consulta e descarregamento dos títulos inseridos nas Bibliotecas Digitais UC Digitalis, UC Pombalina e UC Impactum, pressupõem a aceitação plena e sem reservas dos Termos e Condições de Uso destas Bibliotecas Digitais, disponíveis em https://digitalis.uc.pt/pt-pt/termos.

Conforme exposto nos referidos Termos e Condições de Uso, o descarregamento de títulos de acesso restrito requer uma licença válida de autorização devendo o utilizador aceder ao(s) documento(s) a partir de um endereço de IP da instituição detentora da supramencionada licença.

Ao utilizador é apenas permitido o descarregamento para uso pessoal, pelo que o emprego do(s) título(s) descarregado(s) para outro fim, designadamente comercial, carece de autorização do respetivo autor ou editor da obra.

Na medida em que todas as obras da UC Digitalis se encontram protegidas pelo Código do Direito de Autor e Direitos Conexos e demais legislação aplicável, toda a cópia, parcial ou total, deste documento, nos casos em que é legalmente admitida, deverá conter ou fazer-se acompanhar por este aviso. 
Carlos Camponez

Ana Teresa Peixinho

Coordenação

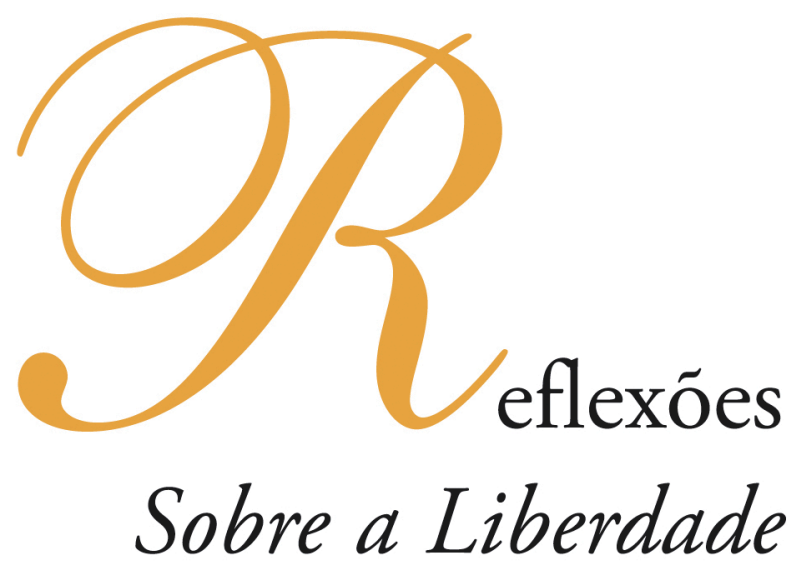

150 anos da obra de John Stuart Mill

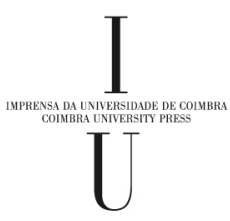


(Página deixada propositadamente em branco) 
iiiiiiiiiie

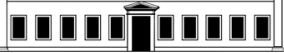

D

0

C

U

M

E

N

T

0

S<smiles>CC1(C)CCC1(C)C</smiles> 
EDIÇĀO

Imprensa da Universidade de Coimbra

URL: http://www.uc.pt/imprensa_uc

Vendas online: http://www.livrariadaimprensa.com

ConCePÇÃo gráficA

António Barros

INFOGRAFIA

Carlos Costa

EXECUÇÃo GRÁFICA

Publidisa

ISBN

978-989-26-0063-5

Depósito Legal

(C) Agosto 2010, Imprensa da Universidade de Coimbra 


\author{
Carlos Camponez \\ Ana Teresa Peixinho \\ Coordenação
}

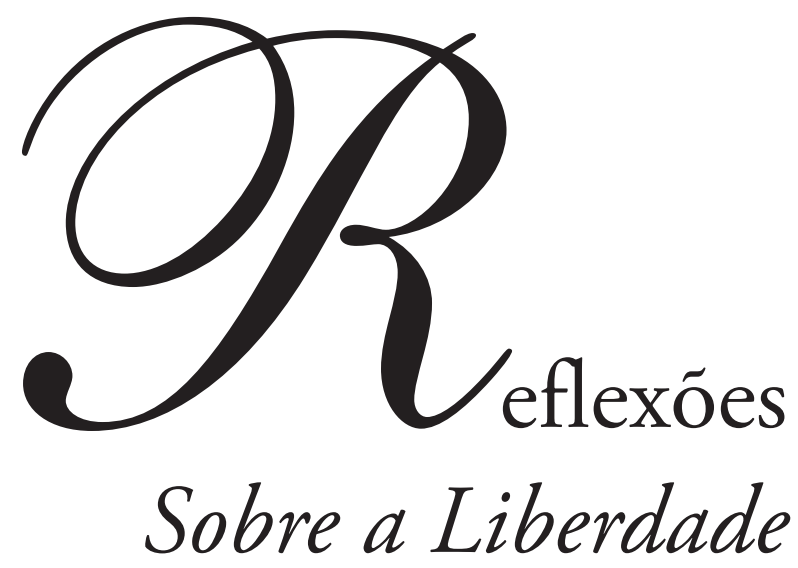

150 anos da obra de John Stuart Mill 
(Página deixada propositadamente em branco) 


\section{SUMÁRIO}

Prefácio - John Stuart Mill: a ÁRvore e a máquina ….................................... 7

Diogo Pires Aurélio

INTRODUÇÁO - LIBERDADE: UM VALOR EM CONSTRUÇÃO

Carlos Camponez

Ana Teresa Peixinho

Sobre A LibERDADE

Manuel Alegre

John Stuart Mill e as geraçóes de feminismos Maria João Silveirinha

John STUart Mill v. Richard Dawkins:

A Liberdade de Expressão e a

Crítica ao Paradigma Evolucionista Dominante

Jónatas E.M. Machado

DA LibERDAdE À TOLERÂNCIA: UMA LEITURA PLURALISTA DO «ON LIBERTY»

Tomaz Castello Branco

John Stuart Mill, A «Tirania da maioria» E O SEU FUtUro

Alexandre Franco de Sá

OS IMPASSES SOBRE A LIBERDADE DE IMPRENSA

NO PENSAMENTO UTILITARISTA

Carlos Camponez

NOTAS BIOGRÁFICAS DOS AUTORES 
(Página deixada propositadamente em branco) 


\section{Prefácio \\ John STUART Mill: A ÁRVORE E A MÁQUina}

\section{Diogo Pires Aurélio}

Raras vezes, na história do pensamento ocidental, a liberdade humana terá sido questionada em termos tão radicais como nos romances de Dostoievski, em particular na alegoria do Grande Inquisidor, apresentada em Os Irmáos Karamazov. O texto, recorde-se, é assumidamente uma ficção no interior da ficção, um esboço de poema confidenciado por Ivan, personagem do romance, a seu irmão Aliocha. Possui, no entanto, o condáo de intuir, de forma literariamente inexcedível, o drama da sociedade moderna, uma sociedade que não consegue pensar-se a si própria sem a liberdade e que, ao mesmo tempo, vê brotar das suas próprias entranhas novas formas de servidão. Ivan imaginou, para o almejado poema, uma segunda incarnaçáo de Cristo, desta vez em Espanha, nos finais da Idade Média, onde um velho cardeal preside à Santa Inquisição. Mais do que um guardião da fé, dever-se-ia chamar-lhe, em termos sartrianos, um guardião da má-fé. O Grande Inquisidor está plenamente convicto de que, abolindo a liberdade, poupando aos homens o tormento da escolha, os tornará felizes. E, assim que vê o Cristo no meio da turba, reconhece-o e manda-o prender. Depois, na "noite sevilhana, escura, quente e inanimada", visita-o na cela e confronta-o com os efeitos perversos da sua pretensão de libertar os homens, soltando-os das amarras da lei antiga:

«Durante quinze séculos, atormentámo-nos com esta liberdade, mas agora está tudo resolvido (...). Fica sabendo que hoje, precisamente hoje, estas pessoas estão mais do que nunca convencidas de que são absolutamente livres e, entretanto, trouxeram a sua liberdade até nós e depositaram-na aos nossos pés. (...) Porque só agora (ele está a falar, é claro, da Inquisição) se tornou possível, pela primeira vez, pensar na felicidade humana. O homem foi criado em rebeldia. Será que os rebeldes podem ser felizes?» ${ }^{1}$

A pergunta, na boca do Grande Inquisidor, soa a retórica. Muito antes, porém, do romance de Dostoievski, ela já se fizera ouvir em tom dramaticamente realista, na boca de muita gente, perante os acontecimentos de 1789 e, sobretudo, de 1793, em França. Quer ao longo de todo o século XIX, quer depois no século XX e mesmo ainda hoje, o seu eco náo parou de se ouvir. Todas as rebeliôes, esses momentos em que os indivíduos se libertam da ordem estabelecida, sempre se fizeram em nome da felicidade, e a Revolução Francesa, desse ponto de vista, não foi excepção. Mas as rebelióes, uma vez triunfantes, convertem-se por norma no seu oposto, sem que os heróis deixem por isso de se afirmar convictos de continuar a agir tendo por única motivação a felicidade comum, mesmo quando recorrem ao terror e chacinam milhóes de adversários. Por sua vez, os indivíduos, cuja espontaneidade natural aparentemente os tornaria rebeldes, experimentam amiúde a tentação de se entregar a um qualquer inquisidor, grande ou pequeno, que os alivie do fardo que é governarem-se a si mesmos, e estiolam, amorfos, numa alucinação de felicidade. Será possível ser feliz sem

1 Fiódor Dostoievski. Os Irmãos Karamazov, trad. de Nina Guerra e Filipe Guerra, Lisboa, Editorial Presença, $1^{\text {a }}$ e $2^{\text {a }}$ partes, vol. I, p. 306. 
a tranquilidade que o ser-se livre impede? Ou a felicidade não reside senão na ilusão da liberdade que os inquisidores prometem e a que chamam de servidão voluntária?

O liberalismo, através de Benjamin Constant, já tentara responder a esta mesma questão, pondo em evidência a necessidade de resguardar a liberdade individual, face ao império da «vontade geral» incarnada no poder do Estado. Contra aquilo que Rousseau ensinara, o facto de uma comunidade obrigar cada um dos seus elementos a ser livre, isto é, a sobrepor a condição de "cidadão» aos seus interesses particulares, afigura-se a um olhar liberal como uma forma de despotismo em tudo igual a qualquer outra. Ser livre, pensa Constant, não implica tanto a participação nas decisóes que se tomam na esfera pública, como o desfrutar de independência e não ser incomodado na esfera privada. Porque há uma diferença, acrescenta, entre os tempos modernos e o tempo antigo na maneira de encarar a liberdade. Ao participarem na deliberaçáo das normas colectivas, os antigos sentiam que "a vontade de cada um tinha uma influência real», encontrando aí prazer e compensação bastantes para o sacrifício que faziam da independência individual à independência colectiva. Pelo contrário, o homem nascido com a civilizaçáo moderna, além de não vislumbrar, estando como está «perdido na multidão", alguma utilidade no seu voto, nem de obter ganhos de felicidade por participar na vida pública, tem à sua disposição «uma variedade infinita de meios», que lhe proporcionam «a felicidade na vida particular» ${ }^{2}$. Não quer dizer que a liberdade à antiga, ou liberdade política, não seja importante. Mas destina-se unicamente a impedir que o arbítrio dos governantes faça imposiçôes desnecessárias, ou seja, a assegurar em última instância as condiçôes para uma efectiva liberdade individual. Conforme Espinosa dissera, um século e meio atrás, «o verdadeiro fim da república é, de facto, a liberdade» ${ }^{3}$. A função das instituiçôes e das leis esgota-se na garantia que elas oferecem aos indivíduos de poderem pensar e agir sem serem incomodados. É, no entanto, impossível prescindir de semelhante função, por mais residual que ela seja, razão por que se torna imprescindível impedir quem a exerce de exorbitar e, desse modo, incorrer no arbítrio. Há sempre, adverte ainda Constant, o risco de, «absorvidos no gozo da nossa independência privada e na procura dos nossos interesses particulares, renunciarmos demasiado facilmente ao nosso direito de participar na vida política» ${ }^{4}$. Longe, pois, de defender que se aliene a capacidade de decidir sobre aquilo que é do interesse de todos, a troco de garantias para decidir sem obstáculos naquilo que é só de cada um, Constant faz depender o gozo da liberdade individual da preservação da liberdade política: «Onde encontraríamos nós estas garantias sem a liberdade política?» ${ }^{5}$.

Entre a liberdade dos antigos e a liberdade dos modernos, ou, para usar a terminologia de Berlin, a liberdade positiva e a liberdade negativa, existe, pois, uma coordenação necessária, mas, ao mesmo tempo, uma subordinação. Ao apontar como única razão de ser da liberdade antiga a salvaguarda da liberdade moderna, Constant subordina, de facto, a primeira à segunda, centrando a política na questão das liberdades individuais e rejeitando uma interferência do Estado no espaço privado dos indivíduos, ainda que fosse em nome da sua felicidade. Antes dele, talvez só Espinosa ${ }^{6}$, na já citada definiçãa dos objectivos da

2 «De la liberté des anciens et des modernes», in: Benjamin Constant, Écrits Politiques. Textes choisis, présentés et annotés par Marcel Gauchet, Paris, Gallimard, 1997, p. 602.

3 Tratado Teológico-Politico, cap. XX, trad. introd. e notas de Diogo Pires Aurélio, $3^{\text {a }}$ edição, integralmente revista, Lisboa, INCM, 2004, p. 385.

4 Benjamin Constant, cit. p. 616.

5 Ibidem, p. 617.

6 Poderíamos referir também Maquiavel, em quem Espinosa se inspira grandemente, não fosse a distância 
república, isentara com a mesma clareza o campo político das funções que por tradição se lhe atribui e que o republicanismo - renascentista, rousseauista ou contemporâneo - retomaria enfaticamente. Mais ou menos platónica, mais ou menos hobbesiana, a tradição manifestou-se sempre favorável à aceitação do poder como uma espécie de último recurso para transformar a condição natural dos indivíduos e aproximá-la de um estado de felicidade, significasse esta a simples segurança, o desenvolvimento económico, a civilização ou a sociedade sem classes. Ora, Constant desconfia, e com razão, dos cuidados desses «bons pastores», que frequentemente os governantes imaginam ser. "Por mais tocante que seja um tão enternecedor interesse», ironiza o autor, "tem de se pedir à autoridade para se quedar nos seus limites. Que ela se limite a ser justa. Nós encarregar-nos-emos de ser felizes». E não há, nesta desconfiança face à autoridade do Estado, uma simples consideração de ordem estratégica, ou mesmo constitucional. Não é por receio (o qual seria, de resto, fundado) dos erros que os governantes cometem, no seu afâ de levar a felicidade aos governados. O problema é antropológico, antes ainda de ser político. Porque «não é só à felicidade, é ao aperfeiçoamento que o nosso destino apela; e a liberdade política é o mais potente, o mais enérgico meio de aperfeiçoamento que nos foi dado pelo Céu». Assim, se o destino dos indivíduos é o aperfeiçoamento contínuo, conforme repete o Iluminismo, e se o principal meio de aperfeiçoamento são as instituiçôes assentes na liberdade, então a liberdade é simultaneamente meio e fim. Aperfeiçoar-se é tornar-se mais livre para continuar a aperfeiçoar-se. $\mathrm{E}$ «mesmo que o povo esteja tranquilo, resta sempre muito a fazer» ${ }^{7}$.

Ao lermos Sobre a Liberdade, a mais conhecida obra de John Stuart Mill, cujo $150^{\circ}$ aniversário motivou, em 2009, os textos agora publicados no presente volume, é quase impossível não evocar esta equação estabelecida por Constant entre liberdade e felicidade. É certo que os termos em que ela se apresenta na obra de Stuart Mill já não são exactamente os mesmos. As marcas de Kant, ainda visíveis na recusa de Constant em amarrar a política a qualquer outro propósito que não a justiça, dão aqui lugar ao empirismo e, sobretudo, ao utilitarismo de que o autor inglês se alimentou, quase literalmente, no berço. "A justiça», segundo Mill, «é apenas o termo apropriado para certas condutas sociais úteis, que são infinitamente mais importantes e, por isso mesmo, se impóem mais absoluta e imperativamente do que quaisquer outras» ${ }^{8}$. A justiça, por outras palavras, é decerto um bem, mas relativo, o mesmo se podendo dizer da igualdade e da própria liberdade, que náo podem considerar-se independentemente da utilidade. "A liberdade, enquanto princípio, não tem nenhuma aplicação num estado de coisas anterior ao momento em que a humanidade se tornou capaz de ser aperfeiçoada (being improved) pela livre e igual discussão»" Em consequência, observa Mill, a liberdade é completamente inadequada, seja em crianças, seja em povos selvagens e bárbaros, com os quais o despotismo seria, em seu entender, um modo adequado e legítimo de lidar. Um pouco à revelia do Iluminismo, que consagra a liberdade como um direito inato, "o único direito inato» na opiniāo de Kant, a liberdade é aqui apresentada como um instrumento que a utilidade poderá aconselhar ou desaconselhar. Náo, obviamente, a utilidade de um particular, nem sequer da maioria, como teremos oportuni-

a que a obra do florentino, pelo seu contexto, se encontra da modernidade, e que impossibilita referi-lo sem a mediação de consideraçóes hermenêuticas que estariam aqui deslocadas.

7 Benjamin Constant, cit., p. 616-618.

8 John Stuart Mill, Utilitarianism, second edition, Indianopolis/Cambridge, Hackett Publishing Company, Inc., 2001, p. 64.

9 On Liberty, London, Penguin Classics, 1985, p. 69 
dade de ver, mas a «utilidade no sentido mais amplo, baseada no interesse permanente do homem como ser progressivo» ${ }^{10}$.

A utilidade é neste contexto um conceito-chave. Tanto Bentham como James Mill, pai de John Stuart, haviam sustentado como princípio justificativo da conduta, tanto dos indivíduos como dos governos, o seu contributo para o bem-estar e a felicidade, não só do agente, mas também de todos os afectados por uma determinada acção. Rejeitando qualquer moral de base religiosa, e bem assim a ética formal de Kant, os utilitaristas avaliam a qualidade do agir humano e das leis em função da utilidade ou quantidade de bem-estar que daí possa advir. Sem dúvida, o prazer é algo de subjectivo, e uma acção que representa prazer para alguém pode implicar a dor de outros, pelo que a natureza ética de uma acçáo só poderá exprimir-se na resultante de prazeres e danos por ela causados. Não quer dizer que o prazer global da sociedade se tenha, por princípio, de sobrepor ao prazer concreto de cada indivíduo. Mas não é difícil perceber que o prazer e o bem-estar individual, pelo menos a médio ou longo prazo, passa pelo bem-estar colectivo, e que é necessário, para assegurar que o bem-estar de uns não prevalece sobre o bem-estar de outros, maximizar a participação democrática, através, por exemplo, de medidas como a concessão do sufrágio universal. A moral utilitarista envolve, pois, uma forte componente política, onde, a par da higiene, saúde e desenvolvimento social, indutores de comodidade e bem-estar, a educação tem um papel decisivo, justamente para consciencializar os indivíduos da interdependência em que se encontram as respectivas condutas. Isso explica, de resto, as repercussóes que a doutrina conheceu entre vários sectores mais radicais do socialismo inglês ${ }^{11}$.

Foi este o ambiente intelectual em que John Stuart Mill se formou e, contrariamente ao que pretendem algumas interpretaçóes, não se pode dizer que dele se tenha alguma vez afastado, pelo menos no essencial ${ }^{12}$. O que, sem dúvida, há de diferente na sua obra é uma especificação, bastante mais acentuada e, ao mesmo tempo, sofisticada em relação à dos utilitaristas seus antecessores, da natureza definitivamente individual do bem-estar. Bentham, com efeito, considerava o prazer como um estado psico-fisiológico subjectivo, susceptível no entanto de ser calculado e promovido a nível colectivo, mediante, por exemplo, a melhoria das condiçôes de vida de que podem usufruir todos os cidadãos. A tabela de prazeres e as fórmulas por ele sugeridas para calcular a felicidade colectiva poderão ter tanto de mecânico como de ingénuo, mas é com base nesse mesmo cálculo que Bentham chega à defesa do bem comum e de políticas sociais avançadas. Mill, por seu turno, sem pôr em causa a importância das condiçóes materiais e, por maioria de razáo, do sistema educativo, distancia-se da rigidez e abstracção que imputa à concepçáo benthamiana dos prazeres e dos indivíduos, sublinhando

10 Ibidem, p. 70. A frase completa diz: «It is proper to say that I forego any advantage which could be derived to my argument from the idea of abstract right as a thing independent of utility. I regard utility as the ultimate appeal on all ethical questions; but it must be utility in the largest sense, grounded in the permanent interests of man as a progressive being».

11 Cfr. H. L. A. Hart, Essays on Bentham: Jurisprudence and Political Philosophy, Oxford University Press, 1982.

12 Um bom exemplo de leituras manifestamente empenhadas em «resgatar» Stuart Mill do utilitarismo é o ensaio de Berlin, onde, apesar de não se concluir que o autor abandonou expressamente - o que representaria, aliás, uma violência aos próprios textos - é no entanto apresentada uma interpretação toda ela assente no pressuposto de que Berlin - «o centro do seu pensamento» o seu "sentimento» - não poderia, malgré lui, incluir-se na corrente filosófica de que o seu pai é um dos expoentes. Cfr. Isaiah Berlin, «John Stuart Mill and the Ends of the Life», in Four Essays on Liberty, Oxford University Press, 1969. Na mesma linha de interpretação, cfr. igualmente J. Plamenatz, The English Utalitarians, Oxford, Basic Blackwell, 1966, p. 132-133. 
a necessidade de atender, não apenas à quantidade, mas também à diferente qualidade dos prazeres. «Seria absurdo», escreve, "que na apreciação de qualquer outra coisa se considerasse tanto a qualidade como a quantidade, e na apreciaçáo do prazer se supusesse que ele depende unicamente da quantidade» ${ }^{13}$. Não quer dizer que haja a priori uma determinada qualidade inscrita na natureza de cada prazer, o que remeteria para um essencialismo em tudo estranho ao pensamento de Mill. Porém, a experiência do prazer conhece matizes, diferenças e graus, os quais a memória compara. É por isso que "poucas criaturas humanas consentiriam ser transformadas num qualquer animal de condição inferior, mesmo prometendo-lhe a mais completa ração de prazeres animalescos». É por isso, também, que «um ser de faculdades mais elevadas exige mais para ser feliz, está provavelmente exposto a sofrer mais agudamente e é, por certo, vulnerável em mais pontos do que um de tipo inferior; mas, apesar destas fragilidades, ele pode realmente não desejar nunca mergulhar naquilo que sente ser um grau de existência mais baixo» ${ }^{14}$. Em resumo, os prazeres apresentam-se empiricamente, não como uma tabela fixada em abstracto e graduada apenas quantitativamente, mas como um processo dinâmico de inscriçốes na subjectividade de cada indivíduo e de cada sociedade, que faz variar em cada época as respectivas escalas valorativas. Deste modo, a felicidade geral é inseparável da complexidade da condição humana em cada um dos indivíduos e em cada um dos seus momentos. E pode, inclusive, deixar de corresponder à resultante abstracta de diferentes desejos individuais de felicidade, como no cálculo de Bentham, para passar a incluir um desejo interiorizado pela educação e a experiência - o desejo do bem comum - a ponto de brotar espontaneamente em cada um dos indivíduos, ao lado de outros que são exclusivamente individuais:

«as leis e os arranjos sociais deviam harmonizar, tanto quanto possível, a felicidade ou (como se lhe poderia chamar em linguagem corrente) o interesse de cada indivíduo com o interesse do todo. (...) A educaçáo e a opinião, que têm um táo grande poder sobre o carácter humano, deviam usar esse poder para criar na mente de cada indivíduo uma associação indissolúvel entre a sua própria felicidade e o bem do todo» ${ }^{15}$.

A mais importante diferença do pensamento de Mill em relação aos seus antecessores, sendo embora resultado da consideração qualitativa dos prazeres, reside, contudo, no plano político, mais concretamente na forma de encarar o regime democrático. Bentham e James Mill defendiam todo o tipo de reformas que fossem favoráveis à democracia, com base no princípio de que a felicidade geral aumentaria tanto mais quanto maior fosse o número de cidadãos a tomar as decisôes de interesse comum. A máxima felicidade do maior número exige a máxima democracia. Reconhecendo embora, tal como Sieyes e os jacobinos, legitimidade à maioria para legislar, eles sabiam que o poder da maioria pode igualmente ser tirânico, e defendiam, por isso, uma representação tão próxima dos representados, e condicionada por estes, quanto possível. Restava, no entanto, uma dificuldade: como fazer com que as escolhas do maior número convirjam para o bem comum, se, por um lado, a grande maioria não possui sequer competência para decidir em causa própria e se, por outro lado,

13 Utilitarianism, cit., p. 8.

14 Ibidem, p. 9.

15 Ibidem, p. 17. Cfr., sobre este ponto, Charles Douglas, John Stuart Mill: A Study of His Philosophy, Edimburgo e Londres, William Blackwood and Sons, 1895, p. 213-216. 
os decisores, mesmo se competentes, no momento da decisão podem sempre deixar de atender à felicidade geral e fixar-se no interesse particular? Para os utilitaristas, a solução de semelhantes dificuldades teria, logicamente, de passar em boa parte pelo investimento na educação, como forma de promover a competência e fazer ver a cada um que a defesa do seu interesse, quando bem calculada, passa necessariamente pela defesa do interesse geral. Stuart Mill, contudo, vai dizer não só algo mais, como também algo mais importante sobre este assunto.

Logo nas primeiras páginas de Sobre a Liberdade, torna-se claro o desvio que o autor opera na reflexão sobre este problema. O insuperável valor da democracia como regime político não está aí em causa, nem tão-pouco o já comprovado risco de ela se manifestar como tirania. A maioria pode tiranizar as minorias, através de todos os meios que se encontram à disposição da autoridade pública. Mas o todo, a sociedade como um todo, também pode tiranizar o indivíduo, na medida em que «o auto-governo de que se fala não é o governo de cada um por si mesmo, mas o governo de cada um por todos os restantes». E, se é necessário estar-se protegido contra a tirania do magistrado, não é menos necessária «a protecção contra a tirania da opiniâo e do sentimento dominantes». Se quer preservar a sua liberdade, o indivíduo entrará inevitavelmente em conflito com a sociedade, além do mais porque a sociedade tende para a uniformização, o apagamento da diferença e o estancamento da mudança, ao passo que os indivíduos tendem a divergir e a ir contra o que estorva o seu livre desenvolvimento. Consequentemente, terá de haver «um limite para a ingerência legítima da opinião colectiva na independência individual ${ }^{16}$.

A sociedade é, por natureza, acrisolamento das condutas nas malhas de um código. A opinião dominante, por sua vez, é um Leviatã informal, com um sistema de leis e puniçôes não escritas, mas nem por isso menos temíveis. Da pressão da autoridade, ainda pode haver, e há, normalmente, recurso. Pelo contrário, o sentimento dominante tritura ou ostracisa qualquer resistência. E, além disso, há um dado novo, que o Ocidente só descobrirá em finais do século XVIII: a igualdade, que triunfa com a democracia, estimula esse sentimento. «Nos tempos de igualdade», escreve Tocqueville, «os homens não têm nenhuma fé uns nos outros, por causa da sua semelhança; mas esta mesma semelhança dá-lhes uma confiança quase ilimitada no juízo do público; porque não lhes parece verosímil que, possuindo todos luzes semelhantes, a verdade náo se encontre do lado do maior número» ${ }^{17}$. O único pára-raios que pode suster as consequências potencialmente totalitárias de um tal sentimento é a liberdade.

A revolução democrática, até certo ponto, liberta. Ao fazer explodir os privilégios da nobreza e toda a galáxia de pequenas diferenças em que se repercutiam os seus ecos e se estruturava a sociedade antiga, a democracia liberta uma classe do jugo de outra classe, um homem da autoridade de outro homem. Deixa, porém, os indivíduos e as famílias entregues a si mesmos, dispersos numa poeira de átomos aonde o Leviatã da sociedade moderna os irá defrontar um a um, reduzindo-os à insignificância de um número e à consequente impotência. Stuart Mill interpreta semelhante desintegraçáo como cristalização, paralisação do movimento que anima a espontaneidade natural de cada indivíduo no processo de auto-aperfeiçoamento. Sobre a Liberdade é um manifesto pela salvação da espontaneidade individual, a partir de um princípio segundo o qual só o prejuízo à espontaneidade alheia pode legitimar que aquela seja travada pela intervenção da sociedade.

16 On Liberty, cit. p. 62-63.

17 Alexis de Tocqueville, De la Démocratie en Amérique, vol. II, Paris, Gallimard, 1961, p. 23. 
«O seu próprio bem, físico ou moral, não é justificação suficiente. Ele não pode ser compelido a fazer ou deixar de fazer uma coisa porque seria melhor para ele fazê-la, porque o faria mais feliz, ou porque, na opiniāo dos outros, seria mais sábio ou mais correcto agir assim» ${ }^{18}$.

De onde provém esta primazia da individualidade sobre a felicidade? Kant afirmara-a com base na categoria de pessoa, que tem na liberdade a sua condição de possibilidade. Mill, por sua vez, apoia-se táo só no reconhecimento do falibilismo humano, o qual impede uma certeza dogmática sobre qualquer enunciado e promove, consequentemente, a possibilidade de aperfeiçoamento a objectivo primeiro do indivíduo e da sociedade. Não existe no horizonte nenhum modelo, teleologicamente postulado, que a ciência devesse copiar de uma vez por todas e em função do qual se devessem orientar os comportamentos. Existe apenas um processo, um dinamismo que, uma vez contrariado, faz a sociedade retroceder irremediavelmente.

«A natureza humana não é uma máquina, que seja construída segundo um modelo e que se ponha a fazer exactamente o trabalho que lhe esteja prescrito, mas uma árvore, que precisa de crescer e desenvolver-se por todos os lados, de acordo com a tendência das forças interiores que fazem dela uma coisa viva» ${ }^{19}$.

Reside aqui o mais decisivo da questão política. Na verdade, a tradição identificara sistematicamente a mudança com a degenerescência e a revoluçáo com a restauraçáo, motivo pelo qual atribuíra prioritariamente ao poder uma funçáo conservadora. Se exceptuarmos Maquiavel, que detecta as virtualidades do confronto e para quem a discussão, o antagonismo, a liberdade, em suma, conferem à sociedade uma outra vida ${ }^{20}$, o humanismo viu sempre no poder um meio de impedir as «alteraçóes» e «desordens» que brotam espontaneamente das paixóes humanas, a fim de impor a paz e a tranquilidade, sem as quais não seria possível viver feliz. Não quer dizer que, desta perspectiva, o poder deva proceder invariavelmente à desvitalização da sociedade. Por razóes de ordem táctica, ele poderá também atear as chamadas "paixôes colectivas» e usar a energia momentaneamente injectada na massa como anestésico da espontaneidade individual. $\mathrm{O}$ resultado, porém, é sempre o mesmo. A sociedade não se desenvolve como um todo, se não se desenvolverem as suas células. Daí que, ao representar a natureza humana como coisa viva, animada por «impulsos» individuais que lhe correm nas veias como energia e seiva, Mill exija do poder uma função diametralmente oposta. Se tentar conservar, cristalizar regras, sentimentos e opinióes, proibindo para tanto a livre discussão, a diferença e a heterodoxia de pensamento e de costumes, o poder estará a ser despótico, isto é, a violentar a sociedade e a retirar-lhe o sangue que a faz desenvolver-se. E como o processo de cristalização tende a emergir directamente da sociedade, produzindo efeitos tanto ou mais devastadores do que ao surgir através da autoridade instituída, o desenvolvimento da natureza humana impóe que o poder, além de não interferir injustificadamente na espontaneidade individual, impeça também que a sociedade o faça.

18 On Liberty, cit., p. 68.

19 Ibidem, p. 123.

20 «Mas nas repúblicas há maior vida, maior ódio, mais desejo de vingança, e [quando são ocupadas] não as deixa, nem pode deixar, repousar a memória da antiga liberdade». O Príncipe, cap. V, trad., introd. e notas de Diogo Pires Aurélio, Lisboa, Círculo de Leitores/Temas e Debates, 2008, p. 132. 
Poderá perguntar-se onde vai Stuart Mill, ao amarrar assim tão enfaticamente a liberdade ao desenvolvimento da natureza humana, encontrar uma justificação para, não só tolerar, como até justificar o despotismo, a que já atrás fizemos referência, no governo dos povos ditos selvagens. É um facto que a certificação de um povo como civilizado, e bem assim o momento em que a sua utilidade requer a liberdade e não o despotismo, surge aqui desprovida de um critério. Para o empirismo de Mill, no entanto, basta a verificaçáo de que tal já aconteceu, há muito tempo, em «todas as naçóes de que precisa de se ocupar nesta obra». E aí, nessas naçóes, "a compulsão, seja directa, seja através de sofrimentos e penalizaçóes por desobediência, já náo é admissível como meio para o seu próprio bem, sendo justificável apenas para a segurança de outros $»^{21}$. Dir-se-ia que a entrada das naçóes na história e o correspondente acesso ao regime da livre discussão, não sendo um facto para que se possa apontar uma data, impóe-se no entanto a posteriori com evidência suficiente. A dada altura, elas entraram no tempo, como uma esfera que imaginássemos fixa e, entretanto, reparássemos que ela se havia posto em movimento, sem contudo sabermos exactamente quando fora. É, de resto, um problema semelhante ao que Tocqueville identifica na explicação da Revoluçáo Francesa: «não houve jamais acontecimentos maiores, conduzidos desde tão longe, melhor preparados e menos previstos» ${ }^{22}$. Tudo nos últimos 700 anos convergira para ela. No entanto, não houve ninguém que desse por isso.

Contra toda a afirmação em abstracto de um direito dos povos à independência e dos indivíduos à liberdade, Mill retira da experiência unicamente a conclusão pragmática e certamente discutível de que, tal como não seria razoável conceder a um povo a liberdade, na ausência da capacidade de auto-aperfeiçoamento pela livre discussão, é absolutamente ilegítimo negar-lha quando ele possui tal capacidade. Negar a liberdade a um povo que atingiu esse estado, é lesar a utilidade geral, "o interesse permanente do homem como ser progressivo». Mas a utilidade pode apresentar diferentes requisitos para diferentes povos, e náo consta que haja "sociedade alguma que esteja no direito de obrigar outra a ser civilizada»" 23 Por idêntica razão, a utilidade impede a concessão aos indivíduos de uma liberdade absoluta. Qualquer sociedade, da mesma forma que proíbe os indivíduos de «se lesarem reciprocamente os interesses», exige a cada um deles que participe «nos trabalhos e sacrifícios que implica o defender a sociedade ou os seus membros de serem prejudicados ou molestados $»^{24}$. Conforme dissemos repetidamente, só a partir da utilidade pode deduzir-se tanto a liberdade como os seus limites. Stuart Mill, na opinião de um dos seus mais conceituados intérpretes, «sustenta que o despotismo do costume e da opiniāo é prejudicial, não porque isso contraria direitos à auto-expressão inerentes ao indivíduo, mas porque se opõe à utilidade. (...) Uma correcta compreensão de $O n$ Liberty, em particular no que toca à intervenção nos assuntos individuais, é impossível sem uma referência ao princípio da utilidade» ${ }^{25}$.

21 On Liberty, cit. p. 69.

22 L'ancien régime et la Révolution, Paris, Gallimard, 1967, p. 57. Poder-se-ia igualmente mencionar aqui toda a especulaçáo que se produziu, ao longo do século XX, no interior do marxismo (maxime, Althusser), sobre a eclosão da Revolução na Rússia, contra tudo o que a teoria deixava antever.

23 On Liberty, cit., p. 161.

24 Ibidem, p. 141. Norberto Bobbio recorre a esta passagem para lembrar, com razão, que «todo o ordenamento jurídico, mesmo o do Estado liberal ideal (que, na realidade, nunca existiu) consiste em preceitos negativos e positivos». Cfr. O Futuro da Democracia, trad. portuguesa de Miguel Serras Pereira, Lisboa, Publicaçóes Dom Quixote, 1988, p. 148.

25 John M. Robson, The Improvement of Mankind. The Social and Political Thought of John Stuart Mill, University of Toronto Press, 1968, p. 184. Cfr. igualmente Charles Douglas, cit. p. 203. 
A utilidade, há que reconhecer, tornou-se entretanto o único fundamento em que actualmente é pensável o "contrato social». No "politeísmo de valores» que vigora nas sociedades ocidentais, dificultando os laços comunitários muito para lá do que Weber e, por maioria de razão, Stuart Mill alguma vez poderiam imaginar, não se vislumbra outro esteio possível, que não seja a utilidade geral, onde assentar e discutir o bem comum. A utilidade, porém, é agora apontada como um último reduto, uma base mínima de negociação, não como um primeiro motor do desenvolvimento, no sentido que lhe atribuía Mill.

Em nome da utilidade, atingiram-se níveis de bem-estar material que jamais se pensara possíveis, milhôes de pessoas libertam-se anualmente da miséria, a esperança de vida, propiciada pela ciência e pelas actuais condiçóes de vida, dir-se-ia crescer sem limites. O número de democracias existentes no globo continua a aumentar. E o próprio grau de instrução das massas, se por instrução entendermos a simples posse de conhecimentos, não tem hoje paralelo com o que acontecia há um século. À primeira vista, dir-se-ia que o ritmo de desenvolvimento acelerou, muito embora o recorrente pesadelo das guerras e a proliferaçáo de outros flagelos mais recentes, como o tráfico de drogas e a sofisticação do crime organizado, o possam ensombrar. Todavia, o eco de Mill que chega até nós não repercute unicamente os seus desideratos, repercute igualmente os seus receios. Podemos, efectivamente, dizer que a liberdade, enquanto meio de auto-desenvolvimento, cresceu, pelo facto de ter crescido o número de democracias, a instrução e a riqueza disponíveis? Ou, pelo contrário, o individualismo democrático prosseguiu o seu trabalho diluente, esvaziando de conteúdo espiritual, ético, político ou outro - primeiro as sociedades, depois os indivíduos, os quais deixa a pairar na insustentável leveza do seu ser e do seu universo virtual? Será que temos de nos render à evidência de que os piores receios do liberalismo aristocrático, tal como este se configurava na obra de Burckardt, de Tocqueville ou de Stuart Mill ${ }^{26}$, se realizam agora como pesadelos na vida contemporânea?

Sob muitos aspectos, é verdade. Libertos das peias que no passado se colocavam à independência da maioria, libertos das leis que impediam a livre expressão e a livre actuação, libertos, enfim, dos condicionalismos que a fome e a miséria colocavam ao desenvolvimento autónomo, os indivíduos parecem usar maioritariamente a liberdade, que a democracia lhes garante, para se submeter livremente à doce escravidão em que o Grande Inquisidor, sob a figura da opinião dominante, da moda ou dos media, lhes promete, de novo, a felicidade. Mas a liçáo de Mill permanece. E o ideal da individualidade continua a ser o único antídoto para o individualismo vazio de uma sociedade que ameaça converter-se em máquina. Como se diz num poema de Cavafy, em tradução de Jorge de Sena:

\author{
Não discuto se sou feliz ou não. \\ Mas de uma coisa faço por lembrar-me sempre: \\ que nessa grande soma - a deles, que eu detesto \\ - de tantas e tantas parcelas, não sou \\ uma delas. Eu nunca fui contado \\ para a soma total. Esta alegria basta.
}

26 Referimo-nos, obviamente, à conhecida obra de Alan S. Kahan, Aristocratic Liberalism. The Social and Political Thought of Jacob Burckardt, John Stuart Mill and Alexis de Tocqueville (1992), New Brunswick (USA) and London (UK), Transaction Publishers, 2001. 
(Página deixada propositadamente em branco) 


\section{INTRODUÇÁO \\ LIBERDADE: UM VALOR EM CONSTRUÇÃO}

Carlos Camponez

\section{Ana Teresa Peixinho}

As ideias não são meras abstracções. A História está repleta de exemplos sobre o poder de as ideias se imporem como acontecimentos transformadores, capazes de criarem novas mundividências, a partir das quais o Homem se recria e reinventa o mundo à sua volta. Se tivéssemos de escolher uma de entre as mais poderosas ideias transformadoras da História, talvez fosse justo eleger a Liberdade. Ela encerra, no seu seio, a maior revolução que a humanidade levou a cabo ao longo da sua existência e é certamente o legado mais importante dos últimos quatro séculos às geraçóes vindouras. A Liberdade constituiu-se nessa vaga de fundo que, no turbilhão das suas águas, rebentou as amarras que permitiram soltar o poder criador do género humano, que esteve na base do progresso técnico, científico, económico, político e cultural. A Liberdade deu origem às grandes revoluçóes encetadas pelo homem ao longo da sua História e sem a qual não seria possível compreender a evolução das sociedades humanas.

Perante tấo importante conceito mobilizador do pensamento e da História, o Departamento de Filosofia, Comunicação e Informação da Faculdade de Letras da Universidade de Coimbra decidiu, a propósito da comemoraçáo dos 150 anos da publicação do livro de John Stuart Mill Sobre a Liberdade, contribuir para retomar uma reflexão que, por mais inesgotável que seja, nem por isso se revela menos importante e decisiva. Deste modo, a 10 de Dezembro de 2009, organizou um colóquio sobre John Stuart Mill, com o objectivo de reunir um conjunto de contributos interdisciplinares que trouxessem novas reflexóes sobre uma das obras emblemáticas daquele que é considerado um dos mais importantes filósofos britânicos do séc. XIX.

Este colóquio construiu-se com contributos de várias áreas científicas, nomeadamente do Direito, da Filosofia, da Comunicação e da Ciência Política. Foi um intenso dia de trabalho e de reflexão, em que foram proferidas sete conferências, muito diversas quer nos temas, quer nos enfoques, mas cujo mote comum foi a celebração do aniversário da célebre obra de Stuart Mill. Este livro é, como tal, fruto dessas contribuiçóes e pretende levar ao público várias reflexóes em torno de um autor incontornável, Stuart Mill, e de um conceito sempre actual, a Liberdade.

No presente texto de introduçáo, mais do que uma mera exposiçáo dos trabalhos apresentados nesse colóquio, traçaremos um percurso de revisitação guiado pelo tema da Liberdade como motor das sociedades e, simultaneamente, como um projecto sempre inacabado. Esta opção sustentará a releitura dos textos aqui propostos, assumindo a Liberdade na sua dupla dimensão de legado e de desafio.

Por um lado, um legado de geraçôes, construído tantas vezes - não é demais recordá-lo com o sangue dos que padeceram nas masmorras da Inquisição, nas praias da Normandia, nos goulags siberianos ou nas celas de tortura dos prisioneiros políticos.

Por outro lado, a Liberdade apresenta-se-nos como um desafio - e é a esta dimensão que daremos aqui especial relevo. Com efeito a Liberdade nunca se nos apresentará como uma conquista definitiva, mas tão-somente como um trajecto cujo caminho é necessário desbravar todos os dias. Trata-se no fundo de uma viagem milenar, que acompanha a evo- 
lução do homem e que o faz desejar a utopia, sonhar, criar e criar-se. Para além disso, é também, uma viagem perpétua, com obstáculos, armadilhas e resistências. Como parece ter percebido muito bem John Stuart Mill, e as leituras sobre o autor póem-no em relevo neste livro, a natureza deste desafio coloca-se numa dupla dimensão: como algo em constante construção; e como um conceito que não está livre de, ele próprio, ser aprisionado pelas lógicas dos poderes do momento.

Em primeiro lugar, o entendimento da Liberdade como um processo constante de construção é ele próprio fundador da ideia de Liberdade. Este legado que recebemos das geraçôes que nos antecederam apresenta-se-nos como algo eternamente inacabado e aí reside a natureza do desafio das geraçôes contemporâneas. Essa realidade é-nos apresentada permanentemente pela constante mobilidade das fronteiras da Liberdade. Bastará para isso recordar o alerta inquietante lançado pelo Freedom House, um grupo de pressão norteamericano com sede em Washington que, no seu relatório de 2010, refere que há quatro anos consecutivos que a Liberdade e os Direitos Humanos estão em regressão em todo o mundo. Segundo ainda o relatório, nas quase quatro décadas em que aquela organização começou a fazer estes estudos, esta é a primeira vez que uma tal regressão das liberdades e dos direitos dos cidadãos se verifica por um período tão alargado.

Fenómenos como a crise económica ou o combate aos terrorismos poderão ajudar-nos a explicar a razão pela qual estejamos hoje mais abertos a admitir a diminuição das fronteiras da Liberdade. Mas como nos recorda Manuel Alegre, a esse facto não será alheia a própria crise de valores das sociedades contemporâneas que se reflecte, nomeadamente, nas suas formas de representação e de confiança mútua.

Manuel Alegre, dada a sua experiência vívida e vivida de privação de Liberdade, vem recordar-nos que não é possível falar dela sem discutir também as formas concretas da sua realização. Por isso, o tema das desigualdades parece ser tão sensível no mundo contemporâneo, marcado pelo crescente fosso entre ricos e pobres. Na verdade, não é coincidência que, em Sobre a Liberdade, Stuart Mill também se tenha inquietado com o aspecto tão arrasador das desigualdades, como sublinha no seu texto Maria João Silveirinha.

Se as desigualdades sócio-económicas, sublinhadas por Alegre, desembocam na privação de Liberdade, as assimetrias de género também são um problema actual que se arrasta há séculos e é responsável por um perigoso desequilíbrio social. A profunda injustiça da situação da mulher em meados do séc. XIX talvez explique a razão pela qual John Stuart Mill tenha sido bem mais sensível à urgência do reconhecimento da igualdade dos direitos entre géneros no espaço público, do que ao estatuto profundamente desigual da mulher no espaço privado, da família e do ambiente doméstico, normalmente suportado no preconceito acerca da sua «natureza» de progenitora e, "por consequência», de ser particularmente dotado de sensibilidade.

Se tivéssemos que demonstrar quanto há de político na «natureza» e nas relaçóes privadas entre sujeitos, esta seria, certamente, uma eloquente base de partida para o fazer. Tanto o argumento em defesa da igualdade da mulher como o reconhecimento da sua diferença podem ser objecto de apropriação pelos discursos mais progressistas como pelos mais conservadores, como a reflexão feminista já percebeu há bastante tempo. O que a nosso ver parece evidente é que o reconhecimento da diferença das mulheres como elemento integrante da sua emancipação só pode realizar-se plenamente quando estiverem asseguradas, à partida, as condiçóes de igualdade. 
A igualdade é, de resto, um tema recorrente que os críticos nunca deixarão de recordar aos liberais. Manuel Alegre fê-lo a propósito de Mill, considerado uma das traves mestras do Liberalismo, ainda que pelo seu pensamento nunca tivesse passado a ideia de um laissez faire laissez passer como mecanismo exclusivo de regulação das sociedades, do qual o Estado deveria estar completamente arredado. Esta questão é particularmente sensível, em especial no campo da liberdade de expressão e da liberdade de imprensa. Como nos recorda Carlos Camponez, evocando o estudo do investigador esloveno Slavko Splichal, em particular no que se refere à liberdade de expressão e à liberdade de imprensa, o livre mercado das ideias muito dificilmente pode ser atribuído a Mill como é comummente aceite dentro de uma certa tradição liberal. Com efeito, Mill, na senda de Tocqueville, pressentiu os perigos que as democracias de massa e os espaços de opinião pública mediatizados poderiam ter para a liberdade de expressão, silenciando as vozes da diferença. Por isso, Mill não foi um entusiasta das potencialidades da democracia, a curto prazo. Também por isso, percebeu que o mercado das ideias e das opinióes maioritárias não é necessariamente espaço de progresso da verdade, como de resto está profusamente demonstrado na história das ideias. Tanto a Liberdade como a verdade têm em comum o facto de permanecerem, qualquer que seja o seu estádio, num projecto inacabado. Reinterpretando José Tomaz Castello Branco, diríamos que a tolerância é a consciência de que existe algo de precário, de incerto e de inacabado na Liberdade e na verdade.

Assim, a liberdade de expressão surge de forma tão sensível como projecto de realização dos indivíduos, mas também das próprias sociedades, na medida em que lhe for permitido, mesmo enquanto opinião minoritária, desempenhar um papel crítico e suscitar uma discussão socialmente vibrante. Se o facto de a diversidade rimar com liberdade pressupuser uma ligação intrínseca entre os dois conceitos, como parece entender Manuel Alegre, então estaremos perante um dos desafios cruciais que se colocam hoje à liberdade de imprensa. No seu ímpeto de responder ao suposto desejo das audiências, num contexto de mercado das ideias, o campo dos media tem-se transformado num poderoso instrumento de uniformização, não obstante a sua pluralidade. No ruído de vozes que se cruzam no espaço público mediatizado, os media asseguram a pluralidade das ideias, sem com isso garantirem necessariamente a diversidade de opinióes.

Esta consciência é premente nas sociedades ocidentais actuais mas esteve já presente na intelectualidade do século XIX. Entre nós, um escritor e homem de letras como Eça de Queirós deixou testemunho dessa sensibilidade em páginas da imprensa do tempo e em cartas a camaradas geracionais. Num conhecido prefácio a Azulejos do Conde de Arnoso, publicado sob a forma epistolar em 1886, afirma:

«Essa coisa tấo maravilhosa, de um mecanismo tão delicado, chamada o indivíduo, desapareceu; e começaram a mover-se as multidóes, governadas por um instinto, por um interesse ou por um entusiasmo. Foi entáo que se sumiu o leitor, antigo leitor, discípulo e confidente, sentado longe dos ruídos incultos sob o claro busto de Minerva, o leitor amigo, com quem se conversava deliciosamente em longos, loquazes «Proémios»: e em lugar dele o homem de letras viu diante de si a turba que se chama o público, que lê alto e à pressa no rumor das ruas».

Esta é também uma das questôes centrais da abordagem que José Tomaz Castello Branco faz na sua reflexão sobre o livro de Mill, ao salientar a importância que as noçóes de 
Liberdade e de tolerância desempenham no seu pensamento. Com efeito, para que a liberdade de expressão seja possível, ela só é realizável um contexto de tolerância. Mas uma tolerância que não seja apenas entendida, tal como no-la descreve o Padre António Vieira, como o sermáo de Santo António que, perante o ostracismo e a surdez dos homens, não teve outra alternativa do que ir pregar aos peixes. De facto, para que a tolerância se possa exercer na sua plenitude, ela deve permanecer como um espaço de «racionalidade crítica»e não apenas como um lugar inconsequente, onde grassa o relativismo, a indiferença e a paz podre do conformismo. A liberdade de expressão num contexto de racionalidade crítica é o espaço que garante a realização dos sujeitos e o progresso das sociedades. Daí a ênfase colocada na Liberdade como poder da palavra: «a poesia é o poder» - dizia Osip Mandelstan, citado por Manuel Alegre. Nesse sentido, talvez fosse oportuno recordar Albert Camus, quando sobre a imprensa dizia que, livre, a imprensa poderia ser boa ou má, mas sem liberdade ela só poderia ser má. Cremos que o mesmo se poderá aplicar às sociedades contemporâneas: sem liberdade de escolha, de opinião e de expressão, só poderemos esperar, a breve trecho, o seu amesquinhamento progressivo.

Este aspecto remete-nos para o segundo ponto que gostaríamos de sublinhar. Se até aqui enfatizámos os aspectos relacionados com a Liberdade como construção contínua, como realização dos sujeitos, como poder da palavra e como condição de progresso da verdade, importa também sublinhar que a ideia de Liberdade como projecto inacabado nos chama a atençáo para o facto de existir nela algo de imperfeito e de nem ela própria estar a salvo dos discursos manipuladores com objectivos ínvios ao seu próprio ideal. Deste modo, considerar a liberdade como um projecto inacabado e um desafio sempre renovado afigurase-nos em si mesma uma ideia libertadora, na medida em que, deste modo, se impede que, na sua procura da perfeição, o Homem se deixe enredar na ilusão de um modelo definitivo de organização social, perante o qual não lhe restaria outra alternativa se não a da sua submissão. Isso mesmo esteve presente nas tentativas de construção das sociedades sem classe e, ironicamente, não deixou de ser sugerido nas ruínas do muro de Berlim, através da ideia que estaríamos a chegar ao Fim da História. Perante esta ideia finalística, o homem estaria à beira de esgotar as suas possibilidades de se pensar, submergido pelo poder de um modelo vencedor e único de realização social.

Com efeito, muito antes de nós, já, pelo menos, os iluministas e os revolucionários franceses perceberam que, mesmo enquanto vaga de fundo, a Liberdade nem sempre se cumpriu historicamente de uma maneira feliz: o seu percurso realiza-se de forma intrinsecamente humana, com os seus sucessos e os seus fracassos, com os seus excessos e omissóes e com os seus ímpetos, hesitaçóes e paradoxos.

Conviria recordar o que a este propósito nos diz Norberto Bobbio, quando sublinha que «historicamente, a falta de liberdade nasce continuamente do próprio sonho da liberdade». Em particular isso verificou-se sob as promessas de uma verdade libertadora que rapidamente acabou por se transformar numa nova prisão para o ser humano. Mill, na senda do que haviam feito já Milton e Voltaire, entre outros, sublinhou como as perseguiçôes não foram capazes de calar a expansão do Cristianismo. No entanto, a Igreja rapidamente se esqueceu disso mesmo e, uma vez no poder, tentou responder à dissidência religiosa e ao livre exercício da razão com os autos, que, desgraçadamente, se chamaram da fé, e com a tentativa de excomungar os caminhos do pensamento e da ciência. Agora, nas sociedades ditas pós-moralistas, em que o religioso se tornou um tanto démodé face aos discursos da 
ciência e do pensamento laico, Jónatas Machado vem mostrar-nos, a propósito do diferendo entre criacionistas e evolucionistas, como o discurso científico, outrora perseguido, também se pode facilmente transformar numa linguagem totalitarista, procurando extirpar da discussão pública outras racionalidades. E o sintoma revelado por esta discussão parece-nos tanto mais pertinente quanto falamos da pretensão das sociedades contemporâneas em abarcar todo o domínio da verdade possível e do discurso público aceitável. A tendência para reduzir o humano a uma dimensão estritamente racional projecta-se nos discursos dominantes da eficácia, da performatividade, do útil, do científico.

Esta problemática não deixa de estar presente na discussão proposta por Alexandre Franco de Sá quando, às tiranias da maioria, contrapóe o poder mobilizador das minorias de se sobreporem à vontade geral, através da manipulação dos discursos públicos, em especial das formas de representaçáo dos media. Assim, aos receios da ditadura da maioria, evocado por Mill e Tocqueville, Alexandre Sá contrapóe o poder das minorias que, fazendo uso da sua capacidade de mobilização, através dos media, são capazes de impor as suas lógicas não menos totalitárias, não obstante o carácter mais ou menos revolucionário do seu discurso. Vivemos essa realidade de forma radical com os fascismos europeus, capazes de transformarem os estados de desencanto dos povos relativamente à política e à sua própria história num campo sedento, onde a propaganda e a manipulação puderam penetrar fundo. A capacidade das minorias campearem o espaço público contemporâneo, recorrendo à sua capacidade de mobilização, através de um discurso atractivo para os media e a opinião pública, é uma questão tanto mais actual quanto falamos de sociedades descrentes da vida política. Com efeito, parafraseando, num outro contexto, Marylin Strathern, é necessário que náo nos deixemos arrastar na tentação de confundirmos propostas de novas liberdades, quando estamos perante velhas tiranias que apenas se tornaram demasiado familiares.

Esse talvez seja o grande perigo das sociedades modernas. Mas esse perigo apenas resulta do facto de o conformismo e da indiferença, que Stuart Mill denunciou, terem deixado às minorias mobilizadas o campo livre da discussão pública. A fragilização da discussão pública interpela-nos directamente sobre a forma como dignificamos o legado de Liberdade das geraçóes que nos antecederam e o modo como queremos ser relembrados pelas geraçôes vindouras. Por isso, talvez a questáo não esteja no poder mobilizador das minorias, mas na crise de valores das sociedades no seu conjunto.

Esse é talvez o verdadeiro sentido da expressão, frequentemente atribuída a Thomas Jefferson, mas que tomámos de um texto de John Dewey, segundo a qual o «preço da liberdade é a eterna vigilância». Esta frase não é, de todo, uma bela chave-de-ouro para um texto difícil de concluir. À luz das discussóes que aqui fazemos, assumimo-la como uma interrogação: na medida em que deixamos que o espaço público seja facilmente colonizado por processos de manipulaçáo de alguns, seremos suficientemente dignos da Liberdade, da nossa precária liberdade? 
(Página deixada propositadamente em branco) 


\section{SOBRe A LiBERDADE}

\section{Manuel Alegre}

«A liberdade - disse Octávio Paz - não é uma filosofia e nem sequer uma ideia: é um movimento de consciência que nos leva, em certos momentos, a pronunciar dois monossílabos: sim e não».

Suspeito que a liberdade se tenha definido mais vezes pelo monossílabo náo do que pelo monossílabo sim. Desde que o primeiro rebelde da primeira tribo recusou a primeira deriva autoritária do primeiro chefe, passando pelo grande mito grego da liberdade, Antígona, aquela que disse não a Creonte e foi enterrar o irmão com as suas próprias mãos, pagando com a vida um acto sublime de desobediência; ou pela revolta de Espártaco contra a tirania de Roma; ou pelos que impuseram ao poder absoluto de João Sem Terra a Primeira Magna Carta, até aos que assaltaram a Bastilha para dar início à Revolução Francesa, e aos colonos que se libertaram da coroa inglesa para fundar a grande democracia americana. Podia vir por aí fora até aos tempos mais próximos e falar dos que por toda a Europa resistiram ao nazismo, ao fascismo e ao estalinismo, e dos que, no meu país, ao longo de quase meio século, de muitas formas pronunciaram contra a Ditadura o monossílabo náo.

Como o poeta Miguel Torga, quando escreveu: «Temos nas nossas mãos/ o terrível poder de recusar».

E que poder é esse?

O próprio poeta o diz: é a «flor da liberdade», «é essa flor que nunca desespera/ no jardim da perpétua primavera».

Um monossílabo, uma pequena palavra, apenas um não, essa «pequena luz bruxuleante» de que falou o poeta Jorge de Sena , essa pequena luz onde, através dos séculos, em certos períodos da História, pulsou a liberdade, contra as sombras, os absolutismos, os totalitarismos e a negação do homem pelo homem, como em Auschwitz ou no Gulag. Uma pequena luz bruxuleante, por vezes a única esperança, o náo proclamado pelo General de Gaulle a 18 de Junho de 1940, o náo ligado ao sim quando Churchill the perguntou o que ele representava e, sozinho, ele respondeu: «A França».

Mas também o não do poeta russo Osip Mandelstam, condenado a morrer num campo de concentração por ter escrito um poema contra Staline. Quando estava a partir para a Sibéria, a mulher julgou que ele estava louco porque ele disse: «A poesia é o poder». Mas não. Não estava louco. Ele sabia que a poesia é o poder porque é um contra-poder absoluto e é por isso que os tiranos têm medo dela.

Hoje as estátuas de Staline foram derrubadas, mas os livros de Mandelstam estão editados em quase todas as línguas do Mundo e, sobretudo, na sua própria língua de que ele é considerado um poeta maior.

Uma pequena luz, um monossílabo.

Mas eis que há cento e cinquenta anos um inglês chamado John Stuart Mill publicou um pequeno livro chamado On Liberty. E nele afirmou a soberania do homem sobre a sua mente, sobre o seu corpo, sobre si mesmo. Ao fazê-lo ele funda a liberdade individual, a moderna autonomia do indivíduo perante o Estado ou qualquer força que se oponha a essa sua suprema soberania sobre si mesmo. 
Passei pessoalmente por essa experiência. A de estar fechado, completamente isolado, interrogado noites e dias por agentes da polícia política. Não tinha defesa nenhuma, não tinha armas, não tinha nada senão essa soberania sobre o meu pensamento, o meu corpo,

a minha vontade, sobre mim mesmo. É uma soberania e um poder que nenhuma polícia, nenhum exército conseguem vencer. A força do homem está na consciência dessa sua terrível e irredutível liberdade interior.

Lembro-me de que a primeira vez que vivi algo de parecido com um estado de graça foi quando, depois de noites e noites de interrogatório, me restituíram à minha cela e eu senti dentro de mim uma paz absoluta, a paz de quem tinha resistido e tinha preservado a suprema soberania sobre si mesmo.

Não pensei, nessa altura, em Stuart Mill. Mas ocorreu-me o martírio de Jean Moulin, o chefe do exército das sombras, as forças de resistência francesa do interior. Preso pela Gestapo em Lyon, foi torturado até à morte. Sabia todos os segredos da Resistência. Mas não disse uma única palavra. Soberania absoluta da liberdade individual. Os dois monossílabos, o não e o sim, magicamente ligados por um homem que soube defender até à morte o segredo, a integridade, a sua soberania pessoal conjugada com a da nação ocupada.

No seu livro Sobre a Liberdade, a preocupação de Stuart Mill é a defesa do indivíduo contra «a tirania da maioria», a afirmação da sua liberdade moral e económica perante o Estado, cuja intervenção na vida das pessoas só se justifica para evitar os danos que possam ser causados a outros. É a trave mestra filosófica do liberalismo. A ela podem recorrer os que hoje, em circunstâncias históricas muito diferentes, defendem o Estado mínimo contra aqueles que, por exemplo como eu, advogam a necessidade de, perante a crise actual, repensar o papel do Estado, não como Estado produtor, mas como Estado estratega, um Estado que, além de assegurar a liberdade e garantias individuais, seja capaz de definir metas sociais, de suprir as falhas de mercado e de ser, ele próprio, instrumento de luta contra as desigualdades.

Voltando a Stuart Mill, creio que se lhe deve a mais completa defesa até então feita da liberdade de expressão. E independentemente da doutrina e dos sistemas políticos a que parece ter dado origem - o liberalismo e o neo-liberalismo, que é um parente do primeiro - deve-se-lhe, de certo modo, a fundação da cidadania moderna. Com efeito, o princípio de que o indivíduo é soberano sobre si próprio, sobre o seu próprio corpo e sobre o seu pensamento está na origem daquilo a que hoje podemos chamar «o poder dos cidadãos», a sua autonomia perante qualquer poder que tente restringir qualquer parcela daquela soberania do homem sobre si mesmo. Uma soberania que, se formos a ver, está consagrada na Declaração Universal dos Direitos do Homem e é inseparável da soberania popular manifestada através do sufrágio democrático e livre.

A Liberdade não é uma abstracção. E não há Liberdade sem liberdades. Quando uma das liberdades, a de pensamento, de associação ou de expressão é ameaçada são todas as outras que estão ameaçadas. Quando uma delas é coarctada é toda a liberdade que é atingida.

Por isso, neste tempo em que renascem, de um lado e de outro, os fundamentalismos, com a sua lógica de excomunhão do outro, do que é diferente, do que tem outra cor, outra religião e não pensa da mesma maneira, neste tempo em que, nas nossas próprias democracias, há uma manifesta crise do sistema de representação e a vida pública está cada vez mais confiscada pelos aparelhos partidários que tendem a substituir-se aos próprios cidadãos, neste tempo em que surgem novas dependências e novos medos, é tão importante celebrar a actualidade e modernidade deste conceito de liberdade individual, proclamado por John Stuart Mill. 
Vários e grandes são os problemas que no mundo contemporâneo se colocam à Liberdade. Em primeiro lugar as desigualdades.

A expansão global dos mercados financeiros liberalizados conduziu ao colapso do sistema financeiro mundial e gerou desigualdades colossais. O nível de desigualdade estrutural criado pela globalização desregrada, restringe, diminui e condiciona o exercício da Liberdade e das liberdades. Os desempregados, os excluídos, os deserdados da vida não têm o mesmo grau de Liberdade daqueles que hoje se apropriam da grande fatia do produto interno bruto de cada país. Não foi por acaso que António Sérgio falou das "condiçóes concretas da liberdade». Ele sabia que só através da igualdade de oportunidades, no emprego, na educação, na cultura, na saúde, etc., se pode chegar a uma vivência plena de Liberdade. E por isso hoje é cada vez mais difícil separar o conceito e a prática da Liberdade do conceito e da prática da igualdade.

Mas também a globalização, esta globalização desregrada, que é a que temos.

A globalização é inelutável. E pode trazer consigo novas oportunidades de conhecimento e desenvolvimento. Mas tal como está também pode trazer crises como a que estamos a viver. Assim como o risco de uniformização cultural e comportamental. O risco de uma espécie de ditadura do mediático e do imediato que faz com que tudo se saiba ao mesmo tempo mas sem tempo para digerir e hierarquizar a informação recebida. Vêem-se e ouvem-se em todo lado as mesmas reportagens, os mesmos filmes, as mesmas imagens e até os mesmos discursos. E até de certo modo na mesma língua. A uniformização mata a diversidade cultural e empobrece a memória e a História do Homem e do Mundo. Em cada língua que morre, diz Georges Steiner, é um pouco de nós que morre também, um pouco da nossa História e da nossa Humanidade.

A diversidade rima com Liberdade. O que ameaça a diversidade ameaça a Liberdade.

É importante aprender o inglês. Mas antes de aprender o inglês é importante aprender o português. Falar e escrever correctamente a nossa língua é um acto de Liberdade e de afirmação da nossa identidade cultural. Um acto de soberania, individual e colectiva. Um acto de resistência, de sobrevivência e de homenagem àquela «lusitana antiga liberdade» de que falou Luís de Camóes.

Mas este é também o tempo do renascimento de certos fantasmas, nomeadamente o racismo, esse mal absoluto, como dizia André Malraux. Quem nega o outro nega-se a si mesmo. Como afirmei uma vez na A.R. criticando então um acto racista, «não há meias liberdades. Quando se ameaça a liberdade de alguém, ameaça-se a liberdade de todos». Recordo que Camóes escreveu em língua portuguesa dois dos mais belos poemas de amor anti-racista, um dedicado a uma mulher negra (As Endechas a Bárbara Cativa) e outro (Alma minha gentil), a uma chinesa. Aqueles que hoje proclamam «Portugal aos Portugueses» estão a fazer uma afirmação contra Portugal e contra os Portugueses. Convém também recordar que somos simultaneamente um povo de emigração e imigração e que, assim como celebramos acordos para que os portugueses possam viver nos países de acolhimento com Liberdade e dignidade, devemos defender a inclusão como política essencial à consolidação da democracia e ao próprio desenvolvimento do nosso país.

$\mathrm{O}$ ataque terrorista às Torres Gémeas em 2001 veio colocar à Liberdade um novo e grave tipo de problema. Não faltaram os apóstolos da guerra de civilizaçóes. E a invasão do Iraque, baseada numa mentira, veio transformar este país num desastre favorável ao crescimento do ódio e da vingança. A resposta de Bush foi um erro de consequências incalculáveis. Por isso a eleição de Obama, para além de ser, em si mesma, um facto cultural 
de grande vitalidade democrática e pedagógica, constitui uma nova esperança para todo o Mundo.

Esperança de que o unilateralismo que caracterizou as decisões de Bush seja substituído pelo reforço do papel das Naçóes Unidas. E que o confronto dê lugar ao tão necessário e urgente diálogo de culturas e civilizaçóes. Esperança também em que no combate contra o terrorismo sejam repostos os princípios fundamentais do Estado de Direito.

No dia em que, em nome da segurança, as democracias abdicarem dos seus valores e dos seus princípios, isso significará a vitória moral do terrorismo. Este é, sem dúvida, um dos grandes desafios que se colocam à Liberdade.

O outro tem a ver, não só com a liberdade individual, mas com a defesa da terra e da sobrevivência da Humanidade. É fundamental que a liberdade humana vença a cegueira do egoísmo e da supremacia dos sistemas económicos sobre a própria sobrevivência.

Como dizia Bertrand Russel:

«A Liberdade é o bem supremo; porque sem ela torna-se impossível a personalidade. A vida e o conhecimento são hoje tão complexos que somente pelo livre debate podemos encontrar o nosso caminho, através dos erros e preconceitos, rumo à perspectiva total que é a verdade».

Mas talvez o principal problema que hoje se coloca aos sistemas fundados na Liberdade seja aquele que muitos autores, nomeadamente Pierre Rosanvallon, chamam a «erosão da confiança». Vivemos num tempo de suspeição e desconfiança. Nos políticos, nas instituiçóes, por vezes na própria democracia. Há quem chegue a falar na dissociação da legitimação e da confiança. Uma sociedade de desconfiança acabaria (ou acabará) por pôr em causa a própria legitimidade política, mesmo quando esta é sufragada pelas urnas. Há, no entanto, quem sustente que esta dissociação sempre existiu, mesmo desde o Acordo do Povo, o primeiro manifesto democrático moderno, publicado em Londres em 1649.

«A legitimidade, segundo Amin Malouf, é o que permite que povos e indivíduos aceitem, sem existir coacção, a autoridade de uma instituição encarnada em homens e considerada portadora de valores partilhados». E acrescenta que há hoje no Mundo «legitimidades extraviadas».

«Há legitimidades mais fortes do que outras - diz ainda Malouf - Mas nenhuma é imutável».

Seja como for, é indiscutível que, depois dos grandes ideais de libertação e de extrema politização vividos nos anos sessenta, há hoje uma crise da elite e um declínio da vida política. Ao mesmo tempo que se manifestam os múltiplos sinais de desinteresse, indiferença, desconfiança. Isto coloca um problema e um desafio à Liberdade.

Porque se é verdade que, mesmo num sistema privado de Liberdade, o indivíduo é o soberano de si mesmo, não é menos verdade que a liberdade individual implica a liberdade colectiva plenamente vivida. O que por sua vez passa pela necessidade e urgência de lutar contra o desencanto e de repor a confiança nas nossas instituiçôes, nos nossos valores e no bem supremo da Liberdade. 


\section{John Stuart Mill e as geraçóes de feminismos}

\section{Maria Joáo Silveirinha}

\section{Introdução: Os caminhos históricos do pensamento feminista}

Para compreender as continuidades e também as especificidades do pensamento feminista de John Stuart Mill, no texto que se segue, iremos traçar, na primeira parte, alguns elementos da história do feminismo até ao tempo do autor e, na segunda parte do texto, faremos uma breve análise do seu trabalho neste campo, defendendo que esse deve ser compreendido num complexo de preocupaçóes sobre a natureza da cidadania. Este percurso é importante porque, nos principais livros de história da teoria política do século XX, o pensamento feminista está praticamente ausente ou é mesmo completamente ignorado; e isso estende-se aos filósofos que assumiram posiçóes feministas. Por exemplo, a História da Teoria Politica de George H. Sabine refere apenas que John Stuart Mill valorizou algumas ideias liberais, como a libertação das mulheres, ideias essas «totalmente desproporcionadas à sua importância», e mais não diz sobre o feminismo de Mill (Sabine, 1968: 711). Muito menos são autoras e autores feministas, como Marie de Gournay, François Poulain de la Barre, Mary Astell e Mary Wollstonecraft sequer mencionadas. E, no entanto, mais do que uma simples questão de historiografia feminista, está em causa a compreensão dos próprios núcleos conceptuais que baseiam a nossa cidadania, como mulheres e homens.

Assim, gostariamos de argumentar que as posiçôes feministas de John Stuart Mill, desenvolvidas em particular no seu texto A Sujeição das Mulheres, se inserem numa longa linha de questionamento da cidadania que coloca no seu centro a ambiguidade da natureza dos sexos, uma discussão que, como veremos, começa muito antes de Mill e se prolonga até hoje, produzindo a multiplicidade de feminismos que caracteriza a luta das mulheres contra a opressão masculina.

O pensamento feminista tem uma longa história, algo descontínua, desde que Christine de Pizan, que viveu em França nos finais do século XIV e princípios de XV, apelou à autoridade das experiências femininas e ao registo de "grandes mulheres» na história para afirmar a igualdade intelectual inata entre homens e mulheres e defender estas últimas contra a misoginia da literatura contemporânea e da autoridade religiosa. Pizan inseria-se assim, no debate público do século XV que veio a ser conhecido como a Querelle des Femmes, sobre a natureza das mulheres ${ }^{27}$.

Embora o trabalho de Pizan e das suas contemporâneas não produzisse nenhum tipo de programa político ou análise do poder, através dele podemos ver que os debates sobre o papel das mulheres na sociedade não só recuam no tempo, muito mais do que até há pouco tempo se presumia, como se centram numa questấo que irá ocupar muitas das discussóes e dos argumentos em torno dos seus direitos: a "questão da natureza das mulheres», que seria desenvolvida em particular durante o Iluminismo, mas que já antes vai criando as suas raízes.

Os argumentos teológicos feministas das Querelles seriam bastante mais elaborados no século XVII, tomando também formas cada vez mais seculares de debate filosófico e polí-

27 Normalmente apontado como o exemplo mais influente desta querela é o texto de Cornelius Agrippa «De nobilitate et praecellentia foeminei sexus» que defende a superioridade do sexo feminino. 
tico, apelando à razáo, em vez da autoridade, e construindo os conceitos que ainda hoje fazem parte do léxico feminista. Nesse sentido, Akkerman e Stuurman (1998) descreveram o século XVII como a era do "feminismo racionalista» na Europa, dado que escritoras como a francesa Marie de Gourney e a holandesa Anna Maria von Schurman basearam as suas exigências igualitárias em princípios cartesianos. $\mathrm{O}$ feminismo continental com uma exposição filosófica mais sistemática e radical do século XVII foi, no entanto, a do francês François Poulain de la Barre nos seus três famosos tratados da igualdade sexual, publicados por volta de 1670. Na verdade, os debates políticos e filosóficos dominantes nesse século seriam quase exclusivamente esgrimidos por homens, mas houve excepçôes, das quais a mais importante em Inglaterra foi provavelmente Mary Astell (1666-1731). Astell antecipou os argumentos da bem mais conhecida Mary Wollstonecraft, defendendo que, embora as mulheres na sociedade do seu tempo parecessem frívolas e incapazes de razão, tal era o produto de uma educação defeituosa e não de qualquer incapacidade natural.

No século XVIII, encontramos os debates filosóficos sobre a natureza da liberdade e racionalidade humana que viriam a tomar forma na Declaração da Independência americana (1776) e na Declaração dos Direitos de Homem e do Cidadão em França (1789).

Em França, o velho regime, como muitos Jacobinos o definiram, tinha sido corrompido pela influência excessiva das mulheres na corte e nos círculos políticos de elite. Só alguns radicais na Revolução (p. ex., Condorcet) eram favoráveis aos direitos das mulheres e os novos direitos expressos na Revolução referiam-se sempre ao homem, não sendo este um termo genérico que as incluísse. Na sua maioria, na verdade, os filósofos do Iluminismo e os líderes das revoluçóes produziram um surpreendente consenso em torno da ideia de que os princípios do individualismo racional não lhes eram aplicáveis.

Em causa estava, uma vez mais, uma certa ideia sobre a natureza emotiva e apaixonada das mulheres, que as tornava incapazes do desenvolvimento pleno da razão e biologicamente desajustadas à esfera pública, ainda que aptas a desempenhar um papel importante como esposas e mães. Isso mesmo encontramos nos escritos de Voltaire, Diderot, Montesquieu e sobretudo Rousseau.

No entanto, a Revolução Francesa também marcou a questão de partida do feminismo europeu moderno, tendo estimulado algumas primeiras exigências sistemáticas dos direitos políticos das mulheres. A eles deram expressão a voz marginal de Condorcet, e as exigências de melhor educação feminina nas primeiras petiçóes à Assembleia Nacional. Tais questóes foram também ferozmente discutidas em panfletos e na imprensa radical, bem como nos clubes políticos de mulheres que apareceram entre 1789 e 1793. A Declaração dos Direitos das Mulheres de uma das mais famosas feministas da Revolução Francesa, Olympe de Gouges, afirmava que "a Mulher é livre e igual ao homem nos seus direitos».

No entanto, como Joan Scott defendeu, estas posiçóes eram bastante paradoxais. A própria Olympe de Gouges, numa afirmação de 1788, descreveu-se a si mesma como "uma mulher que só tem paradoxos e não problemas fáceis de resolver» (Scott, 1996: 4). Ao chamar a atenção para as suas contraditórias exclusóes da ideologia universalista, as mulheres mostravam, pois, a sua "auto-contradição", o «espectáculo perturbador apresentado pelo paradoxo» (Scott, 1996: 10).

Estavam assim criadas as bases conceptuais para o que viria a ser um dos principais dilemas do feminismo liberal: a apresentação da diferença de género como uma forma de eliminar essa mesma diferença. Com efeito, a exigência de direitos iguais negava simultaneamente a relevância da diferença sexual e afirmava a existência das mulheres como 
um grupo sexualmente diferenciado, com interesses e necessidades bem identificados. Este paradoxo marcaria as exigências de direitos políticos, não só no contexto da democracia liberal como, de um modo mais vasto, em toda a história do feminismo.

A aplicação das teorias liberais sobre os direitos civis ao estatuto das mulheres produziria uma análise sistemática da chamada "questão da mulher». As mulheres urbanas, de classe média, foram o grupo social que assumiu a liderança dessa análise, dado que elas tinham mais educaçáo e mais tempo, para começar a pensar em como transformar o sistema político de forma a incluir o sexo feminino. Mas as mulheres activistas, bem como os e as teóricos/as que escreveram sobre estas questóes, discordavam num ponto essencial: como defender os direitos das mulheres. Algumas realçavam as diferenças relativamente aos homens e como essas diferenças as tornavam importantes na vida social, política e económica; outras realçavam a importância das semelhanças, defendendo que as mulheres eram racionais como os homens e, como tal, podiam participar, numa base igual, na vida comum.

Correntes específicas, como o socialismo utópico expresso pelos franceses Saint Simon (1760-1825) e Fourier (1772-1837), pelo britânico Robert Owen (1772-1837) colocaram uma ênfase particular nas relaçóes entre os sexos e dentro do espaço doméstico, sendo as questôes da família e da sexualidade vistas como uma condição prévia e necessária para a transformação da sociedade. Em algumas das versóes destas correntes, defendia-se a diferença das mulheres e até mesmo o seu separatismo.

Em oposição, feministas como Mary Wollstonecraft realçaram que as mulheres tinham as mesmas qualidades que os homens, podendo usar a razão e pensar racionalmente - o que significava que elas deviam ter os mesmos direitos políticos. Esta questão produzia, no entanto, também um dilema a que Pateman (1989) viria a chamar o "Dilema de Wollstonecraft», traduzido nos paradoxos de ambas as vias de acesso à cidadania plena das mulheres que esgrimem a sua semelhança ou a sua diferença com os homens.

Um dos mais importantes trabalhos feministas de influência socialista, a ser publicado na Grã-Bretanha do tempo de John Stuart Mill (1825), seria o de William Thompson e Anna Wheeler, com o extraordinário título Apelo de uma Metade da Raça Humana, as Mulheres, Contra as Pretensóes da Outra Metade, os Homens, de as Conservar em Escravidão Politica Portanto Civil e Doméstica (Appeal of One Half of the Human Race, Women, Against the Pretensions of the Other Half, Men, to Retain Them in Political and Hence Civil and Domestic Slavery). O Apelo era uma resposta ao texto de James Mill, pai de John Stuart, Article on Government (publicado em 1824), no qual ele tinha afirmado que, dado que as mulheres não têm nenhum interesse separado dos dos seus maridos ou pais, não têm qualquer necessidade de representação independente. O Apelo ridicularizou a lógica de Mill e afirmou energicamente a defesa liberal dos direitos iguais, indo bem além de ideias de Wollstonecraft, ao insistir que as mulheres têm direito a plenos direitos políticos, incluindo a representação e a participação em questóes do Estado. A capacidade intelectual das mulheres é, defenderam, pelo menos tão grande quanto a masculina, e as diferenças biológicas nunca podem ser um argumento contra os direitos políticos.

\section{O feminismo de John Stuart Mill: potenciais e as contradiçöes do feminismo liberal}

À luz destas pistas, que nos dão uma melhor compreensão histórica das raízes religiosas, socialistas e mesmo conservadoras do feminismo, podemos agora ver que o feminismo 
britânico de meados do século XIX envolveu uma série de ligaçóes que nos podem fazer questionar o pressuposto de que o feminismo foi um simples derivado do liberalismo. A preocupação, à época vitoriana, com a opressão das mulheres na vida doméstica, no casamento e em todas as formas de relaçôes sexuais produziu, com efeito, uma mistura paradoxal das noçóes liberais da igualdade e dos direitos individuais com ideias religiosas de «virtudes femininas» e ideias radicais de separatismo feminino (Caine, 1993).

Havia, por isso, um número de contradiçôes no coração do feminismo Vitoriano, e o trabalho de John Stuart Mill não esteve isento destas contradições. Nesse sentido, os problemas que as críticas feministas viriam a identificar no seu trabalho não foram exclusivos dele, reflectindo antes dificuldades mais comuns e profundas. Mas, se Mill sofreu uma forte influência dos trabalhos feministas anteriores e do seu tempo, será difícil concordar com Valery Bryson quando refere que «apesar da atenção que o seu trabalho recebeu ele não produziu nenhum novo desenvolvimento teórico» (Bryson, 1992: 54). Vejamos porquê.

Em Mill, o foco da cidadania liberal levou-o a rejeitar as diferenças entre mulheres e homens. E, no entanto, as questóes que ele herdou e depois tratou prolongam-se para o tempo presente e ecoam em versôes contemporâneas do feminismo. Na verdade, podemos introduzir Mill e o seu questionamento sobre a natureza dos sexos num complexo de ideias que liga historicamente as diferentes geraçóes de feminismos europeus (Akkerman e Siep Stuurman, 1998): o renascentista, o racionalista, o iluminista, o utópico, o liberal e o próprio feminismo contemporâneo. Mas é a sua identificação sistemática de alguns problemas na relação entre os sexos que faz de Mill um autor cuja importância esteve bem além do facto de ele ser um homem influente, deputado, a lutar no parlamento Britânico pela causa das mulheres.

Desde muito cedo, Mill revelou um interesse particular pelos problemas do casamento e das relaçóes íntimas. Muito jovem, foi defensor do controle do nascimento. Quando tinha apenas 17 anos, a sua descoberta, num parque de Londres, de uma criança morta, levou-o ao contacto com o liberal malthusiano Francis Place e a distribuir os seus panfletos sobre controlo de nascimento, o que acabaria numa breve detenção por «tentar corromper a pureza da mulher Inglesa» (Packe, apud Fitzpatrick, p. 24). Ao longo da vida, a sua teoria feminista misturar-se-ia com a sua filosofia política do liberalismo e a sua distintiva forma de utilitarismo.

A obra que mais distingue John Stuart Mill como feminista é A Sujeição das Mulheres, livro escrito em 1861 e primeiro publicado em 1869. Embora este livro provocasse uma considerável hostilidade e troça na Grä-Bretanha, apareceu em mais de uma dúzia de países nos primeiros anos da sua publicação e teve um impacto mundial enorme (Bryson, 1992). O comentário feminista recente, contudo, foi em geral muito menos lisonjeiro, e o trabalho de Mill é muitas vezes visto mais como um exemplo dos inevitáveis defeitos da abordagem liberal ao feminismo, do que um dos seus triunfos.

Os argumentos de $A$ Sujeição das Mulheres assentam nos conceitos e nos princípios do liberalismo e do utilitarismo: o valor intrínseco da felicidade liga-se ao auto-desenvolvimento; a justiça, igualdade, autonomia e liberdade unem-se no sentido da melhoria da humanidade (Okin, 2005).

Mill formula assim o argumento fundamental de A Sujeição das Mulheres no seu primeiro parágrafo do seguinte modo:

"... o princípio que regula as relaçôes sociais entre os dois sexos - a subordinação legal de um sexo ao outro - está em si mesmo errado, constituindo hoje um dos principais obstáculos 
ao desenvolvimento humano; e, justamente por isso, deveria ser substituído por um princípio de perfeita igualdade, que não admitisse qualquer poder ou privilégio de um dos lados, nem discriminação do outro (Mill, 2006: 33)».

Mill vê, portanto, o problema da posição das mulheres na sociedade - o problema da sua sujeição - no contexto da sua crença no progresso e prosperidade humana em geral. Qualquer desigualdade representa uma barreira séria ao avanço de uma sociedade e é também um obstáculo à progressão a nível individual, isto é, à melhoria e prosperidade individuais.

A argumentação de Mill está ligada a dois pressupostos fundamentais: por um lado, a ideia de que a igualdade das mulheres perante a lei é um imperativo que advém do próprio princípio da justiça social e, por outro, a ideia de que há uma utilidade social em eliminar a opressão das mulheres, que se traduz em benefício não só para elas, mas para o conjunto da sociedade. Estes dois pressupostos ligam-se numa tese de que a desigualdade das mulheres e dos homens é tanto injusta como inútil e perigosa não só para os indivíduos como para a sociedade (Szapuová, 2006).

$\mathrm{O}$ argumento utilitarista corre, por exemplo, na defesa de que as mulheres devem ter direito a uma melhor educação. As esposas educadas podem dar aos homens conversação inteligente e incentivá-los a uma melhoria contínua. Além disso, como mães melhores, mais inteligentes e mais satisfeitas, essas mulheres serão capazes de criar uma nova geração de cidadãos pensadores, já que educarão as suas crianças a serem também analíticas e estimulantes (Mill, 2006: 194-195).

Além do benefício para a família, retirar barreiras à participação das mulheres na esfera pública resultaria em «duplicar o coeficiente de faculdades mentais disponíveis em maior proveito da humanidade» (Mill, 2006: 190). Havendo uma maior escolha nos cargos políticos ou profissóes, como a medicina ou o direito, melhorar-se-ia certamente a qualidade de políticos, médicos e advogados. A maior concorrência estimularia também o conjunto de pessoas disponíveis - nomeadamente os homens - a melhorar o seu desempenho. Note-se que isto é, afinal, o que as defensoras das quotas vêm há anos a argumentar.

Para Mill, por outro lado, a situação das mulheres estava em plena contradição com tudo aquilo que o liberalismo representava. Nâo temos espaço, nesta intervenção, para ver como ele considerou, no seu trabalho, algumas objecçóes ao avanço das mulheres e como lhes respondeu, mas eu gostaria de realçar a sua objecção ao argumento de que haveria, de facto, diferenças nas posiçóes de homens e mulheres e que estas seriam moldadas pela natureza para os seus actuais papéis. A este argumento respondeu Mill:

"Contesto que alguém conheça, ou possa conhecer, a natureza dos dois sexos, uma vez que só houve ocasião de vê-los na sua presente relação um com o outro (...). Aquilo a que hoje se chama a natureza das mulheres é algo de eminentemente artificial - resultado de uma repressão forçada em determinados sentidos e de uma estimulação anómala noutros» (Mill, 2006: 71-72).

Ou seja, Mill não só nega a possibilidade de conhecer a «natureza das mulheres», como afirma que o que sabemos e o que experenciamos é o resultado de factores culturalmente determinados, como a socialização e a educação e o efeito das circunstâncias sociais nas quais as mulheres vivem. É ainda hoje notável a observação de Mill que: 
"o conhecimento que os homens podem adquirir das mulheres, mesmo que limitado ao que elas têm sido e são, sem falar já no que poderiam ser, é deploravelmente imperfeito e superficial, e assim permanecerá até que as mulheres, elas mesmas, digam tudo o que têm a dizer» (Mill, 2006: 79).

Quando as feministas actuais invocam vozes das mulheres, quando pedem que elas articulem as suas experiências e as suas vidas, ouvimos, pois, um eco de John Stuart Mill.

Um outro ponto em que Mill contribui, de forma decisiva, para as preocupaçóes que ainda hoje são matéria de análise feminista é a sua análise das relaçôes do espaço privado e as consequências destas para o espaço público. A sua noção de que a condição das mulheres no casamento patriarcal é um exemplo da escravidão e que a família, com frequência, exerce um efeito moral prejudicial sobre todos os seus membros, fornece um contraste dramático à comum idealização vitoriana do casamento e da vida da família. Na sua perspectiva, as mulheres não são livres dentro do casamento, e não são livres para não se casar, dado que não podem ter educação ou ganhar os seus rendimentos na esfera pública, estando, por isso, totalmente dependentes dos seus maridos.

A mudança do estatuto legal das mulheres dentro do casamento - por exemplo no que toca ao seu direito à propriedade e a entrar no mercado de trabalho - era portanto absolutamente necessária, com consequências muito práticas para a libertação das mulheres da tirania e da escravidão.

Também a dissecação de Mill dos danos da violência doméstica, incluindo o impacto do poder dos maridos aterrorizarem e infligirem miséria e sofrimento às mulheres e às crianças, antecede muitas das preocupaçôes feministas sobre o âmbito do privado. Além disso, ele sabia bem que a posição das mulheres no casamento e a sua posição na vida pública estão interligadas. Consequentemente, acreditou que as relaçóes de casamento baseadas na parceria e na igualdade transformariam não só o domínio doméstico mas também a esfera pública. Este ponto poderia ser visto como uma antecipação daquele que viria a ser o moto feminista de meados do século XX: o pessoal é político.

É certo que as tensóes presentes no trabalho de Mill entre a defesa da igualdade sexual na área de direitos civis das mulheres e, simultaneamente, uma aceitação implícita dos papéis sexuais tradicionais náo pode ser casualmente rejeitada. Se Mill acredita que as mulheres deveriam ter uma escolha de carreira ou casamento, supóe que a maioria das mulheres provavelmente continuará a preferir o casamento e que esta escolha é o equivalente a escolher uma carreira. Nas suas palavras: «à semelhança de um homem quando escolhe uma profissão, também quando uma mulher se casa, se pode, de um modo geral, considerar que está a escolher a gestão de um lar» (Mill, 2006: 123). Por isso ele defende, manifestando também uma tensão entre liberdade e utilidade, que a maior parte das mulheres não entrarão, de facto, no mercado de trabalho, mas escolherão "a carreira» de esposa e mãe (Mill, 2006: 123-124).

Mill também defende que, uma vez criada uma sociedade justa e igual, a melhor divisão de deveres entre homem e esposa seria que o homem trabalhasse fora de casa e que a mulher cuidasse da família e da casa: «numa situação realmente justa, não será um hábito desejável que a mulher contribua com o seu trabalho para os rendimentos da família» (Mill, 2006: 123).

Várias autoras vêem nestas afirmaçôes de Mill uma prova das inadequaçóes da sua teoria feminista e da ambivalência de Mill sobre o papel das mulheres na sociedade.

Contudo, sem querer pacificar demasiado essas críticas que são extraordinariamente pertinentes, A Sujeição das Mulheres pode ser melhor entendida examinando o contex- 
to histórico no qual foi escrita, as influências pessoais em Mill e outros trabalhos sobre a questão das mulheres e a situação pessoal e política de Mill no momento em que escrevia e publicava este texto (Smith,2001). Tais contextos permitem-nos questionar se Mill não escreveria desse modo, com a misoginia dos parlamentares e do conservadorismo da sociedade vitoriana em mente, optando, assim, por argumentos estratégicos que não ferissem excessivamente a sociedade do seu tempo.

John Stuart Mill não foi apenas devedor de uma linha de questionamento sobre as mulheres como projectou para o presente muitas ambiguidades que hoje se fazem sentir nos debates do feminismo da igualdade e da diferença.

Mas, talvez mais importante, tenha sido a sua análise sistemática da posição hierárquica das mulheres no sistema de género que caracteriza as sociedades de hoje, como as de ontem. Se essa posição era mais claramente identificável ao tempo de Mill, a subordinação nas relaçóes entre homens e mulheres toma hoje, além disso, novos e mais subtis contornos, incluindo a própria disseminação da ideia de que a igualdade para as mulheres está conquistada. Quando hoje ouço vozes que se levantam em favor do argumento de que viveremos uma época de pós-feminismo, não posso deixar de recordar Mill quando diz:

«os homens não querem unicamente a obediência das mulheres, querem também os seus sentimentos. Todos os homens, à excepção dos mais grosseiros, desejam ter, na mulher a que estão intimamente ligados, não uma escrava forçada, mas uma escrava voluntária, e não somente uma escrava, mas uma favorita» (Mill, 2006: 59). É muito possível, com efeito, que sermos pós-feministas, nos torne favoritas aos olhos dos homens...

\section{Bibliografia}

Akkerman, Tjitske, e Siep, Stuurman (1998), «Introduction: Feminism in European history», in: Akkerman, T., e Stuurman, S. (eds.), Perspectives on Feminist Political Thought in European History: From the Middle Ages to the Present, London: Routledge, pp. 1-33.

Akkerman, Tjitske, and Siep, Stuurman, «Perspectives on Feminist Political Thought» in: European History: From the Middle Ages to the Present, London, Routledge, pp. 122-135.

Bryson, Valerie (1992), Feminist political theory: An introduction, London, Macmillan.

Donner, Wendy (1993), «John Stuart Mill’s Liberal Feminism», Philosophical Studies, 69, pp. 155-166.

Elizabeth S. (2001), "John Stuart Mill's The Subjection of Women: a re-examination», Polity, 34 (2): pp.181-203.

Eisenstein, Zillah (1981), The Radical Future of Liberal Feminism, New York, Longman.

Eisenstein, Z. (1984), Feminism and Sexual Equality, New York, Monthly Review Press.

Fitzpatrick, John R. (2006), John Stuart Mill's political Philosophy, London, Continuum.

Mill, John Stuart (2006), A Sujeição das Mulheres, tradução de Benedita Bettencourt, Coimbra, Almedina.

Okin, Susan M. (1979), «John Stuart Mill, Liberal Feminist», in: Women in Western Political Thought, Princeton, Princeton University Press.

Okin, Susan M. (2005), "John Stuart Mill's Feminism: The Subjection of Women and the Improvement of Mankind" in Morales, Maria H. (ed.), Mill's the Subjection of Women, London, Rowman and Littlefield, pp. 24-51.

Pateman, Carole (1989), The Disorder of Women, Cambridge, Polity Press.

Sabine, G.H. (1968), A History of Political Theory, London, Harrap and Company.

Sapiro, Virginia (1998), "A woman's struggle for a language of enlightenment and virtue: Mary Wollstonecraft and Enlightenment 'feminism'", in: Akkerman, T., e Smith.

Scott, Joan (1996), Only Paradoxes to Offer: French Feminists and the Rights of Man, Cambridge, MA, Harvard University Press. 
Szapuová, Mariana (2006), «Mill's Liberal Feminism: Its Legacy and Current Criticism», Prolegomena 5 (2): pp. 179-191.

Thompson, W. e A.Wheeler (1994), Appeal of One Half the Human Race, Women, Against the Pretensions of the Other Half, Men, Bristol, Thoemmes Press. 


\section{John Stuart Mill V. Richard Dawkins: \\ A Liberdade de Expressáo e a \\ Crítica ao Paradigma Evolucionista Dominante}

Jónatas E.M. Machado

O presente artigo pretende assinalar uma dupla efeméride. Em 1859 publicaram-se no Reino Unido duas obras de importância assinalável. Uma foi The Origin of the Species, de Charles Darwin ${ }^{28}$, que lançou as bases do moderno evolucionismo naturalista. A outra foi o ensaio On Liberty, do filósofo inglês John Stuart Mill. Volvidos 150 anos da publicação de uma e outra, afigura-se importante investigar o modo como o evolucionismo e a liberdade de expressão e discussão aberta se cruzam um com um outro. Para esse efeito iremos confrontar as propostas dialógicas de John Stuart Mill com as teses de um dos mais acérrimos defensores do evolucionismo no século XX e XXI, Richard Dawkins, que até há alguns anos atrás ensinou na Universidade de Oxford. Procuraremos ver se e em que medida o evolucionismo de Richard Dawkins convive com a liberdade de discussão e de crítica às suas premissas naturalistas e materialistas. Para isso começaremos com uma síntese do pensamento de John Stuart Mill sobre a liberdade de expressão. Em seguida iremos ver a forma como Richard Dawkins encara o debate entre evolucionistas e criacionistas e o modo como a sua adesão à teoria da evolução se repercute negativamente sobre a própria liberdade de expressão. Finalmente apresentaremos a nossa avaliação crítica, sustentando a actualidade do essencial das propostas de John Stuart Mill no debate em torno da questão das origens, por sinal um dos mais importantes que o ser humano vem travando desde sempre.

O filósofo inglês John Stuart Mill destacou-se, no século XIX, pela sua defesa intransigente de uma ampla e robusta liberdade de expressão com base em argumentos de natureza racional e utilitarista. Temos em mente o seu ensaio On Liberty ${ }^{29}$, obra em que são aproveitados e desenvolvidos alguns dos argumentos articulados, cerca de dois séculos antes, por John Milton, em Areopagitica, na sua veemente defesa da liberdade de expressão contra a censura parlamentar.

A posição de John Stuart Mill marcou profundamente a época vitoriana num tempo de modernização social, florescimento da ciência, progresso técnico, urbanização e industrialização, caracterizado pela consciencialização da relevância do conhecimento científico para a superação de estruturas cognitivas e normativas tradicionais e a organização da vida social. Em nosso entender, os argumentos avançados por John Stuart Mill continuam a ser inteiramente pertinentes hoje. Tanto mais que não faltam hoje vozes que pretendem «dinamizar a discussão» no espaço público a partir da marginalização e do silenciamento das vozes discordantes. Assim sucede no caso dos defensores do novo ateísmo de base evolucionista.

Assiste-se hoje a uma tentativa assumida de promoção do pensamento único no domínio da discussão da questão das origens, com reflexos nas escolas secundárias, nas universidades e no espaço público mediático. Essa tentativa é principalmente encabeçada pelo decano do ateísmo evolucionista Richard Dawkins ${ }^{30}$. Daí que a mesma se apresente como

28 Charles Darwin, Julian Huxley, The Origin Of Species: 150th Anniversary Edition, New York, 2003.

29 John Stuart Mill, On Liberty and Other Essays, Oxford, 1991, 20 ss., esp. 22 ss.

30 Podemos dizer que Richard Dawkins herdou este título de Anthony Flew, o conhecido filósofo britânico 
o caso de estudo, por excelência, para testar a validade e a pertinência das teses de John Stuart Mill. Nas linhas que se seguem procuraremos sintetizar os principais argumentos a favor da liberdade de expressão mobilizados por este pensador liberal e contrapô-los às teses sustentadas por Richard Dawkins.

Para John Stuart Mill, dada a falibilidade e a provisoriedade do pensamento e do conhecimento humanos, nenhuma opinião, maioritária ou minoritária, deve ser silenciada, porque pode dar-se o caso de a mesma ser verdadeira e de se estar, dessa forma, a silenciar uma ideia verdadeira. A história mostra que muitas opinióes num dado momento tidas por verdadeiras se vieram a revelar erradas quando submetidas à crítica e ao confronto com outras opiniōes. E a inversa também é verdadeira, o mesmo sucedendo com a consideração de uma proposiçáo sucessivamente como sendo verdadeira ou falsa. Entre a verdade e a falsidade de uma dada proposição existe, por vezes, um movimento pendular. Para John Stuart Mill, mesmo que uma ideia seja efectivamente verdadeira (o que, como vimos, nem sempre é um dado isento de controvérsia), nem assim se justifica o silenciamento de ideias erradas.

Mesmo a expressão de uma opiniáo errada pode ajudar a refinar, a confirmar e a justificar racionalmente uma ideia correcta, prevenindo a sua transformação em dogma de aceitação acrítica. $\mathrm{O}$ contacto permanente entre a verdade e o erro permite que a aceitação daquela resulte da consciência clara da sua superioridade racional relativamente às opinióes divergentes e nunca de uma tradição, passível inclusivamente de a corromper e degradar com o tempo. Sem excluir a hipótese de mesmo uma ideia errada conter elementos verdadeiros. Assim sucede em muitos casos. Nem sempre é fácil delimitar de forma nítida e incontroversa, onde termina a verdade e onde começa o erro de uma afirmação. Muitas vezes ambos encontram-se entrelaçados, sendo necessário um trabalho crítico persistente, cuidadoso e frequentemente demorado para os desentranhar e separar.

John Stuart Mill defendeu que todo o exercício do poder coercivo restritivo da liberdade individual encontra o seu fundamento na protecçáo da sociedade de quaisquer danos reais iminentes que a mesma possa enfrentar. Para além disso, não existe qualquer outra razáo para restringir a liberdade. $\mathrm{O}$ aperfeiçoamento moral da sociedade pode ser conseguido, não pela força, mas pela argumentação, pela demonstração e pela persuasão. Nos processos dialógicos e conversacionais, os domínios íntimos da consciência devem prevalecer sobre o paternalismo do Estado. O exercício de uma ampla liberdade individual é visto como promovendo, a longo prazo, a maior utilidade para o maior número. O livre desenvolvimento individual afigura-se, não sem um certo optimismo, como a melhor garantia do livre desenvolvimento da humanidade ${ }^{31}$. O exercício de uma ampla liberdade individual, numa sociedade pluralista, encontra-se ao serviço, a longo prazo, da maior utilidade para o maior

que durante seis décadas se destacou na sofisticada defesa filosófica do ateísmo, nos mais diversos palcos mundiais. Recentemente, Anthony Flew decidiu rever a sua posição, aderindo ao deísmo, explicando as suas razóes no livro There Is a God, New York, 2007. Para ele, a existência de um Criador é uma posiçâo racional e cientificamente irrefutável porque 1) a existência de leis naturais no Universo corrobora uma criação racional; 2) a sintonia do Universo para a vida corrobora uma criaçáo racional; 3) a estrutura racional e matemática do Universo, da Vida e do Homem corrobora uma criaçáo racional; 4) a existência de informação semântica codificada no genoma corrobora uma criaçáo racional. Embora Anthony Flew não se tenha convertido a nenhuma religião em especial, ele confessa, nesta sua obra, que se há alguma religiāo digna de consideração séria, ela é o Cristianismo, em virtude daquilo que diz ser a "figura carismática» de Jesus Cristo e o «super-intelecto» do Apóstolo Paulo.

31 Se esse optimismo é justificado em todas as circunstâncias é uma outra questão, que achamos por bem não considerar neste momento. 
número ${ }^{32}$. A retórica de John Stuart Mill sugere que, mesmo do ponto de vista meramente pragmático e utilitarista, existe um perigo óbvio na supressão das opinióes.

A compreensão ampla e robusta da liberdade de expressão propugnada por John Stuart Mill pretende valer em todas as áreas em que possam existir opiniōes divergentes. Não admira, por isso, que John Stuart Mill procure exemplos paradigmáticos daquilo que pretende sustentar dentro das esferas religiosa e científica, tantas vezes compreendidas e tematizadas como estando em oposição. Com isso, ele começa por reconhecer que mesmo na esfera religiosa, tantas vezes acriticamente confundida com a intolerância e o dogmatismo, há lugar para a tensão dialógica e crítica. Têm aqui total pertinência as palavras de John Stuart Mill, no seu ensaio On Liberty, para quem «the most intolerant of the churches, the Roman Catholic Church, even at the canonization of a saint, admits, and listens patiently to, a "devil's advocate». The holiest of man, it appears, cannot be admitted to posthumous honours, until all that the devil can say about him is known and weighed. If even the Newtonian philosophy were not permitted to be questioned, mankind could not feel as complete assurance of its truth as they now do».

Neste trecho, John Stuart Mill consegue discernir na própria Igreja Católica, que ele qualifica como a mais intolerante das Igrejas, a noção de que nas questóes mais importantes para esta confissão religiosa, mesmo aquilo que parece evidente e desejável, como a canonização de um santo, deve ser sujeito ao contraditório e ao exame crítico contundente. É claro, que John Stuart Mill não deixa de notar a intolerância religiosa que em seu entender caracterizava a Igreja Católica. A sua referência parece ter, entre outros, o objectivo de evidenciar alguma inconsistência e contradição interna entre as doutrinas cristãs e a prática da Igreja Católica no domínio da liberdade de expressão. Em todo o caso, os debates teológicos que ao longo dos séculos se vêm travando, sobre os mais variados temas, dentro e entre as confissóes religiosas, confirmam que, a despeito de práticas institucionais, indesmentíveis, de intolerância e perseguição, a religião em si mesma nunca foi um espaço para o monolitismo discursivo acrítico, como por vezes se pretende sugerir.

Para além disso, as palavras de John Stuart Mill remetem para o domínio da ciência e da confrontação de ideias dentro desse espaço, através de um outro exemplo também deliberadamente extremado. Em seu entender, mesmo a filosofia newtoniana, cuja veracidade ninguém disputava no seu tempo, deveria poder ser abertamente questionada, a fim de ser testada no confronto das ideias. Como é sabido, Isaac Newton foi um dos maiores cientistas de todos os tempos. Convencido de que a ciência consistia em pensar os pensamentos de Deus depois de Deus, Newton desenvolveu a teoria da gravitação universal e as suas três leis do movimento. Além disso, ele demonstrou matematicamente que essas leis se aplicam igualmente aos céus e à Terra. Os princípios desenvolvidos por Isaac Newton foram considerados durante muito tempo uma descrição correcta da realidade. O próprio John Stuart Mill estava convencido da inatacabilidade dos seus fundamentos científicos. Por isso mesmo ele invocou Newton no seu exemplo.

O seu objectivo consistia em defender que mesmo uma teoria, como a de Isaac Newton, geralmente considerada factualmente correcta e imune à refutação, deveria ser continuamente sujeita a exame crítico e ao confronto com outras ideias. Isso só iria contribuir para

32 Jeremy Waldron, «Religious Contributions in Public Deliberation», 30, San Diego Law Review, 1993, 817 ss. e 836 ss, discutindo o papel da discussão de assuntos religiosos à luz da concepção de mercado das ideias de John Stuart Mill. 
confirmar e reforçar o seu estatuto de correcção científica, assegurando permanentemente as pessoas acerca da sua confiabilidade. De acordo com John Stuart Mill, mesmo que uma opinião seja tida por factualmente correcta pela maioria, ainda assim importa que ela mantenha o contacto com as ideias incorrectas e seja achada superior a elas.

Os desenvolvimentos posteriores viriam dar razão à insistência de John Stuart Mill na liberdade de discussão, embora desmentissem a sua crença na inatacabilidade de Isaac Newton. Afinal, a filosofia newtoniana, considerada inatacável no seu tempo, tem vindo a evidenciar importantes insuficiências. Por isso a mesma tem vindo a ser progressivamente complementada e substituída por novos modelos, teóricos, como a teoria da relatividade geral e especial, a física quântica ou a(s) teoria(s) das cordas. Ou seja, mesmo aquilo que é considerado verdadeiro pela maioria dos cientistas numa dada época nunca pode deixar de ser livre e abertamente questionado. A concordância da maioria, só por si, não é suficiente para estabelecer a verdade de uma proposição. A presunção da verdade de uma determinada afirmação depende sempre da sua capacidade para resistir, na esfera de discurso público, a afirmaçốes que possam ser feitas em sentido contrário. Neste sentido, a presunção de verdade de uma afirmação nunca pode ser o resultado do proteccionismo intelectual, que procure impermeabilizar essa afirmação à crítica e isolá-la de toda a discussão.

Para John Stuart Mill ${ }^{33}$, uma coisa é presumir que uma afirmação é verdadeira porque a mesma não foi refutada apesar de existirem todas as oportunidades para o fazer. Daí resulta a convicção da sua maior aptidão, na medida em que conseguiu superiorizar-se a outras ideias menos aptas. Ainda assim, trata-se apenas de uma presunção de verdade, ilidível pela emergência de posteriores observaçóes, conhecimentos e modelos explicativos. Outra coisa, muito diferente, é partir do princípio de que uma doutrina é verdadeira, com o objectivo de impedir que a mesma possa ser abertamente discutida e refutada. Isto já é absolutamente ilegítimo. Esta era uma prática recorrente no tempo de John Stuart Mill, contra a qual este se insurgia de forma veemente. A mesma era associada ao dogmatismo autoritário de algumas instituiçôes religiosas e políticas. Ela era incompatível com a liberdade de consciência e com a autodeterminação individual e colectiva. A mesma manifestava-se na condenaçáo de hereges, apóstatas e cismáticos ou na existência de delitos de opinião e na perseguição política. Para John Stuart Mill nenhuma ideia, independentemente da sua natureza e do seu conteúdo, poderia ser presumida como verdadeira e usada para fundamentar, a partir dessa presunção, a perseguição e o silenciamento das ideias opostas. Nenhuma afirmação pode ser protegida da crítica e da refutação. Nenhuma questão transita verdadeiramente em julgado no tribunal da razão humana. Para Mill não havia lugar para máximas como «Roma Locuta causa finita».

Em face deste entendimento, o recente livro The Greatest Show on Earth, Evidence of Evolution, de Richard Dawkins, constitui um interessante teste à relevância actual do ensaio On Liberty, de John Stuart Mill. O mesmo coloca importantes desafios à liberdade de pensamento e de expressão, tão valorizados por este importante filósofo liberal e utilitarista do século XIX. Em Richard Dawkins, um dos mais proeminentes ateus evolucionistas da actualidade, encontramos uma atitude diametralmente oposta à preconizada por John Stuart Mill. A estratégia de Richard Dawkins para a promoção da teoria da evolução das espécies, consiste na defesa do silenciamento de todas as opinióes que lhe sejam contrárias, em franco contraste com a abertura racional e dialógica que John Stuart Mill demonstrava

33 Mill, On Liberty and Other Essays, ed. cit., p. 24. 
em todas as matérias. Daí que nos pareçam relevantes algumas consideraçóes de enquadramento, para que se possa compreender a relação entre aquela obra e o pensamento de John Stuart Mill.

Richard Dawkins é um conhecido Professor de Oxford que ao longo de várias décadas tem vindo a defender ardentemente a teoria da evolução das espécies, como fundamento do ateísmo, com base em livros como The Selfish Gene, The Devil's Chaplain, Climbing Mount Improbable, The Ancestor's Tale, etc. O seu penúltimo livro deu pelo nome The God Delusion, evidenciando um ateísmo militante que mesmo alguns ateus consideram extremista. Particularmente interessante é o facto de o alvo primordial do seu ataque ser o Deus da Bíblia, de quem se diz que criou o Universo em seis dias e descansou ao sétimo dia; que terá castigado a humanidade com um dilúvio global, há cerca de 4500 anos; que terá escolhido Abraão, Isaque e Jacó, a quem mudou o nome para Israel, para assinalar a sua presença na História; de quem os escritos antigos dizem ter encarnado na figura histórica de Jesus Cristo, por sinal a mais influente em toda a história da humanidade. É este Deus, e não outro, que incomoda profundamente Richard Dawkins.

Curiosamente, Richard Dawkins não deixa de censurar moralmente esse Deus, de uma forma veemente, embora sem nunca explicar onde vai buscar a superioridade e autoridade moral para o fazer, nem o necessário critério objectivo de moralidade para realizar essa tarefa de forma bem sucedida. Tanto mais, quanto é certo que Richard Dawkins reconhece que num universo sem Deus toda a moralidade é o resultado de preferências subjectivas relativas e iguais entre si. Pelo que, teríamos apenas um confronto entre as preferências subjectivas de Richard Dawkins e as dos autores da Bíblia, sem qualquer critério objectivo para decidir do mérito de umas e outras. Não obstante, aquele que pretende ser o seu argumento central, sobre "a radical improbabilidade de um Deus mais complexo do que o Universo", dá mostras de uma ingenuidade retórica pueril, que pode convencer os incautos mas que é facilmente neutralizável com argumentos filosóficos e teológicos básicos. Talvez por estar consciente dessa fraqueza substancial da sua argumentação Richard Dawkins tenha sentido a necessidade de, pouco tempo depois, editar um novo livro sobre a teoria da evolução. A afirmação de que Deus não passa de uma ilusão, um delírio ou uma alucinação radicalmente improvável, seria insuficiente para resolver a questão.

O capítulo introdutório do livro The Greatest Show on Earth começa com a confissão de que em todos os livros anteriores Richard Dawkins sempre assumiu a evolução, sem ter realmente apresentado evidência de evolução. Esta confissão é apropriada e só vem corroborar aqueles que desde há muito vinham dizendo isso mesmo sobre a obra de Richard Dawkins. Neste último trabalho, Richard Dawkins propóe-se finalmente apresentar aquilo que ele designa como o "elo em falta», em toda a sua obra: toda a evidência da teoria da evoluçáo, que ele julga ser esmagadora. Nem por isso ele deixa de intensificar o seu ataque ad hominem aos criacionistas. Esta estratégia evidencia, provavelmente, alguma insegurança relativamente à posição que pretende sustentar. Os argumentos científicos parecem não ser suficientes, sendo necessário o esforço ulterior de denegrir quem deles discorde. Não é este o momento de discutir a questão de saber se a evidência apresentada no livro The Greatest Show On Earth é realmente esmagadora, como pretende o autor, ou até mesmo a questão de saber se se está aí realmente perante evidência de evolução ou apenas diante de evidência da adesão $a$ priori a uma visão naturalista do mundo, que descarta à partida a existência de Deus e que, consequentemente, interpreta os escritos bíblicos, os seres vivos, as rochas, os fósseis e os isótopos como se Deus não existisse e como se não se revelasse na história humana. 
Interessante, para o tema da liberdade de discussão e de expressão, é a tentativa empreendida por Richard Dawkins no sentido de estigmatizar e ridicularizar os seus opositores criacionistas, por sinal os principais visados nas suas diatribes. Provavelmente o objectivo consiste em levar as pessoas a não quererem sequer ouvir os contra-argumentos que possam ser mobilizados contra a perspectiva evolucionista, a partir de várias frentes, de natureza histórica, científica, filosófica, epistemológica e teológica. No seu entender, importa que a perspectiva evolucionista seja apregoada sem contestação, conseguindo uma posição monopolista na esfera de discurso público. Já há muito que Richard Dawkins vinha sustentando que quem não acredita na teoria da evolução o faz apenas porque é «ignorante, estúpido ou louco (ou perverso) ${ }^{34}$ ».

Na obra The Greatest Show On Earth, o autor vilipendia asperamente todos quantos pretendam discutir a evidência por ele apresentada. A sua estratégia de combate poderia ser resumida assim: «deixo-vos aqui as evidências da evolução das espécies, juntamente com o apelo para que não dêem ouvidos a todos quantos as pretendam discutir e refutar. Confiem em mim». A par de uma apresentação de factos observáveis acompanhados da sua interpretação evolucionista (curiosamente alguns deles refutados escassas semanas após a publicação do livro) Richard Dawkins procura desferir um violento ataque ad hominem aos opositores da teoria da evoluçáo das espécies, na expectativa de que isso seja suficiente para blindá-la contra qualquer discussão ou crítica.

Para além da estratégia tradicional de dirigir insultos e impropérios aos opositores da teoria da evolução das espécies, particularmente àqueles que defendem um criacionismo recente compatível com os escritos bíblicos, Richard Dawkins procura apresentá-los como negadores da história, equiparados aos actuais negadores do Holocausto e a hipotéticos negadores do Império Romano, não merecendo por isso um espaço igual na esfera pública, nas universidades e nas escolas públicas e privadas. Pelo contrário, a estratégia de Dawkins aponta no sentido da sua colocação sob apertada supervisão estadual, como se depreende de uma carta citada pelo próprio, redigida ao então Primeiro-Ministro britânico Tony Blair, em que se defendeu a vigilância atenta de uma escola cristá, britânica, em que o criacionismo era ensinado a par do evolucionismo. Curiosamente, esta era uma escola onde os alunos tinham obtido excelentes classificaçôes nos exames nacionais das disciplinas científicas.

A novidade retórica apresentada por Richard Dawkins consiste em aproveitar-se da polémica em torno dos negadores do Holocausto e procurar estendê-la a quantos negam a teoria da evolução das espécies. Uns e outros teriam em comum a irracionalidade de negarem factos historicamente comprovados. Para conferir maior plausibilidade a este truque retórico, Richard Dawkins convida o leitor a imaginar o que seria ter professores das Universidades ou escolas secundárias que negassem a existência do Império Romano, embora não se conheça ninguém nessas condiçôes. $\mathrm{O}$ essencial do seu argumento é: se é absurdo negar o Holocausto ou o Império Romano, também o é negar a evolução das espécies, na medida em que se trata nos três casos de factos objectivamente comprovados. Embora o negacionismo histórico seja agora a principal estratégia para denegrir e degradar todos quantos rejeitam a evoluçáo das espécies, ao longo da sua obra o autor recorre frequentemente a outras técnicas de estigmatização, não se coibindo de chamar «ignorantes» e mesmo "perversos» a todos quantos pretendam argumentar contra a teoria da evolução.

34 «Put Your Money on Evolution», The New York Times Review of Books, April 9, 1989, pp. 34-35. Apud John Lennox, God's Undertaker Oxford, England: Lion Hudson, 2007, p. 93. 
Em todo o caso, a estratégia argumentativa adoptada por Richard Dawkins traz, em si mesma, as sementes da sua própria refutação. Em primeiro lugar, porque ela pretende apelidar de negadores da história precisamente aqueles que mais a sério levam o testemunho inscrito em documentos antigos de fidedignidade histórica e arqueologicamente comprovada ao longo dos séculos. Nos escritos bíblicos, canónicos e apócrifos, encontram-se detalhadas referências históricas aos povos da Mesopotâmia e do Médio Oriente, bem como aos impérios egípcio, assírio, babilónio, persa, grego e romano. Por sua vez, nos escritos do Novo Testamento são feitas referências precisas e historicamente comprováveis a figuras (b.g. César Augusto, Quirino, Pilatos, Félix e Festo), locais (v.g. Cesareia; Roma) e instituiçôes jurídicas do Império Romano (v.g. pena de morte por crucificação, recurso para César). Não se conhece qualquer cientista, historiador ou líder religioso que negue a existência do Império Romano. Daí que não faça qualquer sentido equiparar a rejeição da evolução das espécies à negação hipotética do império romano. Trata-se aí de um artifício de retórica sofística, de uma forma de pirotecnia argumentativa, com o único objectivo de deslumbrar, atordoar e distrair os leitores.

Do mesmo modo, a corrente negacionista do Holocausto é menos notável hoje por se tratar de um movimento dotado de pretensóes historiográficas consistentes e plausíveis, do que por ser um ataque deliberado e malicioso à dignidade do povo judeu e à subsistência do Estado de Israel, criado 10 anos depois da Noite de Cristal, por sinal realidades sobre as quais amplamente se discorre nos escritos hebraicos, precisamente aqueles que estáo na mira do ataque sistemático de Richard Dawkins. Por outras palavras, não se afigura descabido afirmar que Adolph Hitler pretendia uma «solução final» para os judeus, ao passo que Richard Dawkins pretende uma «solução final» para os escritos hebraicos que fundamentam a identidade dos judeus, a começar pelos primeiros capítulos do livro de Génesis. Uma análise da obra de Richard Dawkins permite concluir que estes escritos, e não qualquer outra obra religiosa ou mitológica da antiguidade, são os principais visados pelas suas diatribes. Este padrão não deixa de ser intrigante e significativo, especialmente quando avaliado à luz da narrativa teológica contida nos textos bíblicos.

Richard Dawkins acusa os opositores da teoria da evolução de negarem a história, quando ele próprio rejeita importantes relatos históricos, pessoal e geograficamente referenciados e circunstanciados, de alguns dos eventos, locais e personagens mais marcantes da história da humanidade, cuja relevância é ainda hoje decisiva para compreender alguns dos mais difíceis problemas que a humanidade enfrenta no século XXI. A verdade é que se fossemos a fazer a história do Holocausto, que aconteceu há apenas 60 anos, com base unicamente na análise científica de ossos e crânios, desconsiderando todos os testemunhos históricos, como parece ser a metodologia preferida por Richard Dawkins, estaríamos muito mal. Com efeito, recentemente descobriu-se que o crânio que durante anos se dizia ser de Adolph Hitler era, afinal, de uma mulher! ${ }^{35}$

No entanto, existe um ponto crucial em que a pretensa analogia que Richard Dawkins procura estabelecer entre a negação do Holocausto e a negação do Império Romano é destruída pela argumentação do próprio. O Holocausto aconteceu há escassas décadas, havendo dele amplas e consistentes evidências físicas, cinematográficas, documentais e relatos

35 «Fresh Doubts Over Hitler's Death After Tests on Bullet Hole Skull Reveal It Belonged to a Women», Mail Online, Mail Foreign Service, 28 de Setembro de 2009; "DNA test shows Hitler skull is that of a woman", Word News.com.au, 29 de Setembro de 2009. 
de testemunhas oculares, algumas delas ainda vivas. Por sua vez, do Império Romano surgem-nos, não apenas uma grande quantidade de documentos históricos, para além de vestígios arqueológicos e arquitectónicos muito bem preservados em toda a Europa e praticamente ao longo de toda a bacia mediterrânica. O problema de Richard Dawkins é que, como o próprio reconhece expressamente, ninguém testemunhou a origem acidental da vida nem a evoluçáo das espécies a partir de um antepassado comum, nem documentou o respectivo processo. Esta é uma diferença fundamental que inviabiliza a analogia de Dawkins entre os negadores, reais ou hipotéticos, do Holocausto e do Império Romano e aqueles que rejeitam a teoria da evolução das espécies. O Império Romano e o Holocausto foram observados e documentados historiograficamente por muitos. A origem acidental da vida e a evolução das espécies a partir de um antepassado comum nunca foram observados por ninguém, resultando de inferências e extrapolaçóes feitas no presente, por pessoas que vivem no presente, a partir de dados observados no presente, com base em visóes do mundo sustentadas no presente.

Para o próprio Richard Dawkins, a evolução das espécies é como um crime que ninguém presenciou e que apenas deixou vestígios que devem ser hoje apresentados num tribunal. Dito de outro modo, Richard Dawkins compara a evolução das espécies com a cena de um crime que terá acontecido no passado, não observado, com todos os vestígios diante de nós. Repare-se, porém, que Richard Dawkins começa logo por avançar a ideia de que houve um crime, mesmo quando sublinha que ninguém presenciou o evento. Mas entáo como é que ele sabe? Como é que ele pode assegurar a priori que se tratou realmente de um crime? A retórica de Richard Dawkins denuncia o facto de que ele parte para as evidências com uma ideia pré-concebida! Sucede que, mesmo no seu exemplo, a ocorrência de um crime deveria resultar de uma inferência feita a posteriori, a partir das evidências recolhidas. Mas ainda assim trata-se apenas uma interpretação possível da presença de um cadáver.

A experiência ensina-nos que numa alegada cena de um crime nem tudo é o que parece. Para uns pode ser óbvio ter-se tratado de um crime. Outros poderão sustentar que a evidência é mais facilmente compatível com a ocorrência de um acidente ou de um suicídio. Por outro lado, mesmo tratando-se de um crime, o criminoso pode ser quem menos se espera. É necessário analisar cuidadosamente toda a evidência, examinar atentamente todos os pontos de vista e sujeitar os vários argumentos a uma análise crítica rigorosa. E mesmo as decisóes de condenação podem ter que ser reabertas diante de novos dados. Da mesma maneira, a evolução das espécies, não tendo sido observada por ninguém, é apenas uma interpretação possível da informação codificada no genoma, das similaridades genéticas, dos fósseis, das rochas, dos isótopos, etc. Todavia, não está excluída a existência de outras interpretaçóes para os mesmos dados empíricos observáveis. Nem se pode descartar muitos dados novos que todos os dias vêm obrigar a rever teorias e modelos dominantes. Em última análise, a interpretação que é feita dos dados observados é indissociável das crenças com que se parte sobre o que terá acontecido no passado distante não observado. A metodologia de John Stuart Mill, para quem mesmo as ideias tidas como certas deviam estar abertas à discussão e à crítica, revela-se de inteira relevância nesta temática.

Ao tentar silenciar os criacionistas, chamando-lhes falsamente «negadores da história», Richard Dawkins quer chegar sozinho àquilo que designa a priori como uma «cena do crime». Com base nas suas ideias pré-concebidas ele pretende poder livremente escolher as evidências que mais lhe interessam, por corroborarem a sua convicção de que houve um crime, e interpretá-las do modo que acha conveniente e apresentar a sua versão ao juiz, 
só ele, sem mais ninguém. Ele não quer que ninguém o confronte com outras evidências para além das que ele considera relevantes, nem com outras interpretaçóes possíveis para a evidência apresentada.

Richard Dawkins compara a defesa da teoria da evolução com a ideia de que se trata algo como apresentar as evidências de que houve um crime a um tribunal. Escusado será dizer que em qualquer tribunal digno desse nome, a metodologia proposta por Richard Dawkins seria inaceitável. Um juiz imparcial iria sempre admitir todas as provas que lhe fossem trazidas pelas partes na controvérsia e todas as inferências produzidas com base nelas. Só assim seria possível determinar, para além de qualquer dúvida razoável, se realmente houve crime e, se foi esse o caso, quem foi o criminoso. Ou seja, uma avaliação independente e imparcial nunca consideraria decisivo o facto de uma das partes de uma controvérsia estar convencida da bondade dos seus argumentos para, a partir daí, tentar impor a sua tese e silenciar as opinióes divergentes. Num tribunal são sempre admitidos argumentos e contra-argumentos, porque os vestígios não falam por si. São sempre os intervenientes no processo que falam por eles.

Richard Dawkins é um daqueles autores que assume que as suas concepçôes são verdadeiras, não porque as mesmas não sejam passíveis de discussão e crítica, mas para que as mesmas não sejam passíveis de discussão e crítica. Neste sentido, ele coloca-se claramente nos antípodas da abertura intelectual e conversacional preconizada por John Stuart Mill. Esta posição de partida tem levado Richard Dawkins a recusar-se a defender publicamente o seu mais recente livro nos debates com cientistas criacionistas para que tem sido desafiado ${ }^{36}$. Naturalmente, depois de lhes chamar negadores da história, ignorantes, estúpidos, loucos ou perversos, Richard Dawkins teria alguma dificuldade em explicar aos seus seguidores porque é que aceitaria discutir com eles.

Essa estratégia é particularmente conveniente, porque lhe permite granjear uma aura de superioridade racional e científica, sem ter que se sujeitar à incerteza do confronto directo com os seus opositores. Para dar uma aparência de sustentabilidade teórica à sua posição de fuga ao confronto com os críticos da teoria da evolução das espécies, Richard Dawkins chega mesmo a lançar as bases de uma teoria da liberdade de expressão a partir das suas próprias premissas evolutivas. Para ele é claro que «Darwin locuta, causa finita!». Em vez de sujeitar as premissas evolucionistas à discussão, Richard Dawkins coloca-as como fundamento e limite da discussão.

Isso é conseguido a partir da concepção «memética» da liberdade de expressão. Richard Dawkins compara as ideias, que designa por «memes», aos genes, desse modo enfatizando o seu carácter auto-replicante e a sua capacidade para ganharem vida própria, escapando ao controlo dos próprios indivíduos que as produzem ${ }^{37}$. De acordo com esta concepção, as ideias seriam replicadores impessoais sem qualquer vínculo necessário à mente huma$\mathrm{na}^{38}$. Apesar de o argumento de Richard Dawkins ter o mérito de acentuar os elementos competitivos da luta de ideias, o mesmo não deixa de ter as suas fragilidades. Desde logo, ele apoia-se numa redução naturalista das ideias a meros estados cerebrais, ou a processos

36 World atheist convention rejects Australian creationist debate challenge, by Dr Carl Wieland, Published: 1 January 2010(GMT+10) http://creation.com/global-atheists-reject-debate-challenge

37 Richard Dawkins, The Extended Phenotype: The Long Reach of the Gene, Oxford University Press, 1999, p. 97 ss.

38 Jeffrey Evans Stake, "Are We Buyers or Hosts? A Memetic Approach to the First Amendment", 52, Alabama Law Review, 2001, p. 1213. 
físico-químicos, podendo conduzir, se levada às suas últimas consequências, à negação da própria racionalidade humana.

Além disso, este argumento ignora o facto de que, no contexto das ideias, a selecção operada, longe de se basear em processos aleatórios e naturais, é sempre mediada pela experiência, pela inteligência e pelos interesses humanos. De resto, muitos casos há em que as ideias que triunfam não são necessariamente as mais aptas, quando tomadas em si mesmas, mas simplesmente aquelas que resultaram do triunfo ideológico e coercivo dos grupos sociais política, económica e militarmente mais poderosos numa determinada conjuntura histórica. Diante desta realidade, a despersonalização e a autonomização das ideias como simples replicadores, desvalorizando a humanidade da sua génese, pode ser utilizada para justificar a censura das ideias que sejam pontualmente consideradas como nocivas e perigosas. E isso, a pretexto de se estar, desse modo, apenas a censurar ideias e não a silenciar pessoas, na sua qualidade de titulares do direito à liberdade de expressão. Como se vê, Richard Dawkins não apenas pretende promover dogmaticamente a teoria da evolução das espécies, furtando-a a toda a discussão, como não se coíbe de construir uma teoria evolucionista da liberdade de expressão "feita à medida», onde as perspectivas contrárias são consideradas simples "vírus» meméticos auto-replicantes que devem ser «apagados» por serem considerados prejudiciais ${ }^{39}$. Este entendimento está claramente nos antípodas da concepção dialógica aberta e desinibida de John Stuart Mill. É claro, neste momento, que o ateu evolucionista Richard Dawkins está longe de partilhar da mesma convicção forte de uma ampla liberdade de discussão.

A questão das origens, com especial relevo para o debate entre as teses opostas de criação e evolução, é hoje daquelas que gera uma das mais acesas controvérsias. John Stuart Mill seria certamente o primeiro a afirmar que essa discussão deve ser levada a cabo de forma livre e aberta. Em sentido contrário, Richard Dawkins pretende sugerir que a teoria da evolução não apenas deve ser aceite sem discussão, como deve fundamentar e limitar toda e qualquer discussão. Para ele, qualquer opinião que seja mobilizada contra a teoria da evolução das espécies é absolutamente inútil e indigna de consideração. Richard Dawkins está inteiramente convencido de que a afirmação da evolução das espécies é única proposição verdadeiramente útil e digna de consideração. Mas será realmente assim? Pemitimo-nos, a este propósito, traduzir livremente John Stuart Mill, quando este observa que «a utilidade de uma opinião é, em si mesma, uma questão de opinião: tão questionável, tão aberta à discussão pública, tão carecida de discussão como a opinião em si mesma». Por outras palavras, a opinião de que a evoluçáo é um facto ou de que nada na biologia faz sentido sem a teoria da evolução não passam de opiniốes questionáveis e abertas à discussão.

Em teoria, é tão legítimo sustentar que a evidência de evolução revela um mundo sem design, como a proposição contrária, de que a evidência de design revela um mundo sem evolução. Sobre os defensores destas diferentes posiçôes impende o mesmo ónus da fun-

39 Um outro problema é que a tese dos «memes» conduz, em última análise, a que a teoria da evoluçâo e a tese dos «memes» sejam reduzidas elas próprias à categoria de simples vírus auto-replicante, de relevância impessoal, acabando por rebaixar o seu estatuto intelectual e epistemológico. $\mathrm{Na}$ verdade, o risco de degradação racional e epistemológica já há muito anda associado à teoria da evolução. O próprio Charles Darwin reconheceu o problema quando indagou: «But then with me the horrid doubt always arises whether the convictions of man's mind, which has been developed from the mind of the lower animals, are of any value or at all trustworthy. Would any one trust in the convictions of a monkey's mind, if there are any convictions in such a mind?», Letter 13230 Darwin, C. R. to Graham, William, 3 July 1881. 
damentação racional e empírica e da persuasão pública, independentemente das mundividências que possam estar subjacentes a uma e a outra. Nenhuma destas questóes se pode considerar encerrada por «decreto", com base numa qualquer noção de proteccionismo epistémico. Admitir a livre circulação de ideias sobre a origem do Universo, da Vida e do Homem que não pressuponham a existência de um Criador, ou designer inteligente, e proibir todas as teorias que explorem a possibilidade da existência de um tal Criador ou designer, não é compatível com uma concepção ampla e aberta da liberdade de expressão e discussão. A questão das origens é táo importante e estimulante que deveria ser livremente analisada e debatida no espaço público, num contexto exploratório, que não de doutrinação, onde todos os argumentos possam ser livremente mobilizados e contestados ${ }^{40}$. A essência da liberdade de expressão consiste justamente em garantir que todas as ideias fiquem sujeitas ao debate e à crítica no mercado livre das ideias, de forma a assegurar que só as mais aptas sobrevivem. Seria extraordinariamente irónico que (logo) o darwinismo, que apregoa a sobrevivência do mais apto, pretendesse permanecer imune à discussão, à crítica e à comparação com modelos explicativos alternativos.

Em conclusão, pode observar-se que Richard Dawkins passa uma boa parte do seu tempo a dizer que as pessoas náo devem escutar os criacionistas, devendo pensar por elas próprias. Para ele, isso parece significar que apenas o devem escutar a ele quando se trata de discutir a questão da origem do Universo, da vida e do ser humano. Em contraposição, John Stuart Mill diria que as pessoas podem e devem apresentar e discutir livremente todas as opinióes, submetendo-as à crítica pela contraposição de umas com as outras, mesmo quando as mesmas parecem ser inatacáveis, e tomando em seguida as suas decisóes autonomamente. Este procedimento dialógico aberto tem o mérito de contribuir para a validação das convicções individuais ao mesmo tempo que afirma os valores da racionalidade e da autonomia humanas. O mesmo não sucede com a tese sustentada por Richard Dawkins, que conduz à despersonalização das ideias e facilita a censura daqueles que forem contrárias ao paradigma evolucionista dominante. A tese de John Stuart Mill continua a ser a mais amiga da liberdade de expressão e da dignidade da pessoa humana. Curiosamente, já o Apóstolo Paulo recomendava a mesma metodologia quando recomendava aos cristãos de Tessalónica: «examinai tudo e retende o bem $»^{41}$.

40 Veja-se, designadamente, Thomas Nagel, «Public Education and Intelligent Design», Philosophy \& Public Affairs, Vol. 36, issue 2, 2008, considerando plenamente constitucional a discussão das hipóteses de criação (intelligent design) nas escolas públicas.

41 I Tessalonicenses 5:21. 
(Página deixada propositadamente em branco) 


\title{
DA LIBERDADE À TOLERÂNCIA: \\ UMA LEITURA PLURALISTA DO «ON LibERTY»
}

\section{Tomaz Castello Branco}

\begin{abstract}
A parte realmente convincente do argumento de Mill é aquela em que ele mostra
quão frequentemente a intolerância esteve do lado da falsidade.

O cepticismo, ou a dúvida, é o parente legítimo da tolerância.
\end{abstract}

Frederic William Maitland, Liberty and Equality (1875)

O ensaio "Sobre a Liberdade», de John Stuart Mill, é frequentemente apontado como uma das mais vigorosas apologias da liberdade individual alguma vez escritas. Não obstante, gostaríamos de sugerir que este ensaio também comporta, em paralelo, uma segunda apologia. $\mathrm{Na}$ verdade, ele pode, e deve, ser lido sob o prisma de um outro valor: o da tolerância.

Lido o ensaio sob este enfoque, podemos dele extrair duas grandes linhas de argumento que confluem na sustentação deste valor eminentemente político. Designamos estas duas linhas como o argumento da liberdade e o argumento do conhecimento. A primeira decorre directamente, claro está, do próprio princípio da liberdade, também conhecido como princípio do dano.

O objecto deste ensaio é o de estatuir um princípio muito simples, com o intuito de governar absolutamente as relaçóes entre a sociedade e o indivíduo sob a forma de compulsão e controlo, quer os meios utilizados sejam a força física sob a forma de penalidades legais, ou a coerção moral da opinião pública. Esse princípio é o de que o único fim para o qual a espécie humana está mandatada, individual ou colectivamente, para interferir com a liberdade de acção de algum de entre os seus, é o da auto-protecção. Que o único propósito para o qual o poder pode ser legitimamente exercido sobre qualquer membro de uma comunidade civilizada, contra a sua vontade, é o de prevenir o dano a terceiros. O seu próprio bem, físico ou moral, não é mandato suficiente.

«(...) A única parte da conduta de quem quer que seja, pela qual se é responsável perante a sociedade, é aquela que diz respeito a terceiros. Na parte que apenas diz respeito a si próprio, a sua independência é, por direito, absoluta. Sobre si próprio, sobre o seu próprio corpo e mente, o indivíduo é soberano» (Mill, 1962: 135).

Do ponto de vista do exercício do poder - e, não se deve nunca perder de vista que a aplicação do princípio de Mill não se restringe ao poder político organizado e institucionalizado no aparelho de Estado, mas a toda e qualquer forma de poder que possa exercer a sua influência sobre o indivíduo contra a vontade deste - e também, seguramente, por força da sua própria formulação negativa, o que aqui está verdadeiramente em causa é a estatuiçáo de um princípio de tolerância, cuja extensão se considera inversamente proporcional aos danos que possa causar. Esta interpretação encontra eco em Mary Warnock quando, referindo-se ao «harm principle», afirma que:

"O argumento de Mill é o de que o único limite à tolerância, a única razão válida para não tolerar um tipo de comportamento, é que este comportamento cause dano a outras pessoas que não aquelas que o praticam» (Warnock, 1987: 123. 
No mesmo sentido pronuncia-se Glyn Morgan:

«Independentemente das palavras para o expressar, o propósito [do harm principle] permanece o de identificar precisamente onde se traçam as fronteiras entre a liberdade protegida e a coerçâo legítima, porque estas fronteiras marcam os limites da tolerância» (Morgan, 2008: 147).

Aliás, é esta conexão estreita entre a liberdade e a tolerância que também Isaiah Berlin estabelece quando, antes de apresentar a definição do conceito de liberdade negativa, procura situá-la na resposta a uma pergunta específica:

"Qual é a área na qual o sujeito - uma pessoa ou grupo de pessoas - é, ou deve ser deixada em paz para fazer, ou ser, aquilo que ela é capaz de fazer, ou ser, sem a interferência de outras pessoas?» (Berlin, 1969: 121-2).

A tolerância surge, assim, como reflexo, ou melhor, como o verdadeiro pano de fundo da liberdade individual concebida de forma negativa. Ou, dito de outra forma, a conceptualização negativa da liberdade não é mais do que a adequação da reflexão da liberdade ao princípio da tolerância. Será essa, afinal, nas palavras de Mill, «a única liberdade merecedora do nome» (Mill, 1962: 138).

\section{O argumento do conhecimento como justificaçáo da Liberdade}

No segundo Capítulo do On Liberty, Stuart Mill avança uma segunda linha de argumento que surge como principal justificação de um elemento fundamental da liberdade individual: a liberdade de expressão. Esta linha, que designámos como argumento do conhecimento, parte da sua crença na humanidade como espécie essencialmente autocriativa, num crescimento perpétuo resultante das chamadas "experiências em vivência» (experiments in living); parte, no fundo, da sua visão das pessoas como «seres em progresso». Mill acredita na liberdade como condição básica para que a espécie humana, como um todo, avance e progrida. Neste sentido, uma das principais justificaçôes, senão a principal, em que assenta o princípio do dano é a da garantia de um espaço de tolerância, táo alargado quanto possível. Esse espaço, na linha do que designámos como o argumento do conhecimento, tem como consequência a máxima abertura à liberdade de expressão. Para a visão progressista de Mill, a Liberdade é o verdadeiro motor do progresso humano. ${ }^{42}$

«O maior mal é o que é feito àqueles que não são heréticos, e cujo completo desenvolvimento mental é prejudicado, e a sua razão tolhida, pelo medo da heresia. Quem pode calcular o que o mundo perde na multidáo de intelectos promissores combinados com caracteres tí-

42 Esta é uma ideia que, no quadro da teoria política mais contemporânea, é indissociável do pensamento de Hayek. A sua defesa da Liberdade como o mais revolucionário desencadeador do progresso humano é marcante em toda a sua obra e verdadeiramente emblemática do arranque do seu argumento em The Road to Serfdom. Neste sentido, o liberalismo aparece como o culminar ou, pelo menos, o estádio mais avançado, de uma longuíssima senda de progresso tornada possível pela afirmação da Liberdade. Os dois grandes planos operativos da Liberdade seriam o comércio e a ciência. São eles os motores do progresso humano; motores movidos a Liberdade. A lógica hayekiana é simples: quanto maior for a liberdade, maior será a aceleração do progresso (V. Hayek, 1991: 10-12). 
midos, que não ousam perseguir nenhuma linha de pensamento arrojada, vigorosa e independente» (Mill, 1962: 160).

A tolerância é, assim, uma condição para a Liberdade e esta, na medida em que é fundamental para o desenvolvimento do conhecimento, para o progresso. Como Glyn Morgan bem aponta, «Mill estava absolutamente correcto quando apontava que o estado do conhecimento é a determinante principal da mudança social» (Morgan, 2008: 162). Para Stuart Mill, inglês oitocentista, no auge do poder imperial britânico, a principal virtude da sua sociedade - herdeira da primeira grande revoluçáo industrial, eixo do comércio internacional, mas também refúgio para os mais diversos dissidentes intelectuais que nela encontravam a paz e a segurança (e a tolerância?) necessárias para o desenvolvimento das suas propostas, tantas vezes revolucionárias -, aquela que lhe garantia o seu poder, quase hegemónico, residia, fundamentalmente, na sua capacidade de manter vivo um processo de conhecimento cujo desenvolvimento intensivo liderava nos mais diversos campos do saber.

Mill vê o processo e desenvolvimento do conhecimento como uma «busca interminável» ${ }^{43}$ pela verdade. Uma busca que nunca estará terminada, ou melhor, cujo término nunca poderemos definir, precisamente por causa da natureza incompleta e falível do conhecimento humano. Ora, é precisamente esta concepção falibilista do conhecimento humano que está na base da sua reflexão e justificação do valor da tolerância. Assim entendido, o falibilismo de Mill pode ser visto sob duas perspectivas fundamentais e interdependentes: uma primeira, que, assentando na ideia da incompletude do permanente processo do conhecimento, convida à diversidade, isto é, que procura manter em aberto o espaço de discussão e de confronto de pontos de vista acerca da verdade; numa segunda perspectiva, o falibilismo milliano impede que qualquer dos pontos de vista em conflito possa arrogar-se da pretensão de pôr um fim ao processo do conhecimento.

De acordo com Mill, o próprio erro é útil ao processo de conhecimento. Por mais evidente que seja, a sua expressão, tornando-o evidente, contribuirá para clarificar e fortalecer a verdade. Por essa mesma razão, a expressão do erro deve ser politicamente protegida conquanto, claro está, não seja causadora de danos a terceiros.

«A verdade ganha mais mesmo com os erros daquele que, com o devido estudo e preparação, pensa por si próprio, que pelas opiniốes verdadeiras daqueles que só as sustentam porque, eles próprios, não são capazes de pensar» (Mill, 1962: 160).

Assim, qualquer tentativa de purificação do processo de conhecimento, nomeadamente através do silenciamento de opinióes que consideramos serem erradas, é indesejável, porque prejudicial para o próprio processo de conhecimento. A opiniáo silenciada poderá ser errada, mas o seu silenciamento é um erro ainda maior. E, se a manifestaçáo de uma opiniāo errada é merecedora de tolerância, a tentativa do seu silenciamento não o será.

A propósito, diz Mill:

«(...) embora a opinião silenciada seja errada, ela pode conter, e muito frequentemente contém, uma porção da verdade; e, uma vez que a opiniáo geral ou prevalente sobre qualquer assunto raramente, ou nunca, contém a verdade na sua totalidade, só pela colisão de opiniôes

43 A expressão é de Karl Popper (V. Popper, 2002). 
adversas poderá ter o remanescente da verdade alguma hipótese de alguma vez ser alcançado» (Mill, 1962: 180).

Para Mill, não há qualquer dúvida que o «mal formidável», o pior dos males, "não é o conflito violento entre partes da verdade, mas a silenciosa supressão de uma das suas metades» (Mill, 1962: 180). Neste sentido, a prática da tolerância, traduzida na liberdade de expressão, é, não apenas consentânea, mas essencial ao próprio processo de busca da verdade - processo esse que é elementar à própria concepção da espécie humana como espécie em progresso permanente (progressive beings).

\section{O erro e a verdade como reconciliaçáo e combinação de opostos}

Mas, se o erro deve continuar a ser admitido ao confronto permanente de opinióes, também a verdade, mesmo admitindo a hipótese de a termos alcançado em definitivo, na sua totalidade, nem por isso deve ser isenta do escrutínio permanente a que as opinióes devem ser sujeitas:

«(...) mesmo se uma determinada opinião for, não apenas verdade, mas toda a verdade, a menos que possa ser sujeita à contestação honesta e vigorosa, e o for efectivamente, ela será tomada, pela maioria daqueles que a aceitarem, como se tratasse de um preconceito, com pouco sentido ou compreensão dos seus fundamentos racionais» (Mill, 1962: 180-1).

No limite, a própria expressão, intolerante, daquele que se arroga detentor de toda a verdade, deve, também ela, ser tolerada. Esse será «o preço a pagar por um bem inestimável». É certo que uma tal arrogância, «a pretensão exclusiva feita por uma parte da verdade como sendo a sua totalidade, deve e tem que ser contestada». Mas isso não significa que mesmo ela possa ser suprimida: «ela pode ser lamentada, mas tem que ser tolerada» (Mill, 1962: 179).

«A não ser que as opinióes favoráveis à democracia e à aristocracia, à propriedade e à igualdade, à cooperaçáo e à competição, ao luxo e à abstinência, à socialidade e à individualidade, à liberdade e à disciplina, e a todos os outros antagonismos presentes na vida prática, sejam expressos com igual liberdade, e promovidos e defendidos com igual talento e energia, não há qualquer hipótese de ambos os elementos obterem o que lhes é de direito: uma escala certamente subirá e a outra descerá. A verdade, nos grandes assuntos práticos da vida, é (...) uma questão de reconciliação e combinação de opostos» (Mill, 1962: 175).

Esta é uma conclusão que Mill repete com frequência. Esta é uma conclusão que aponta abertamente para uma configuraçáo pluralista do conhecimento dos valores, na medida em que admite e assinala, não apenas o conflito entre o verdadeiro e o errado, mas o conflito no seio da própria verdade. Nas palavras do próprio Mill:

«Considerámos duas hipóteses: que a opinião recebida possa ser falsa, e uma qualquer outra opinião, consequentemente, verdadeira; ou que, sendo a opinião recebida verdadeira, um conflito com o erro que se lhe opõe seja essencial para uma clara apreensão e um sentimento profundo da sua verdade. Mas há um caso mais comum que estes; quando as doutrinas conflituantes, ao invés, de serem uma verdadeira e a outra falsa partilham a verdade entre elas» (Mill, 1962: 173). 
E aqui Mill revela um apurado «sentido da realidade» no que diz respeito à reflexão epistemológica sobre o humano e sobre o político. Contrariamente a áreas do conhecimento, como a matemática, "onde não há nada a dizer acerca do lado errado da questáo", onde "todo o argumento repousa sobre um dos lados», no domínio da ética encontramos frequentemente disputas onde pudemos facilmente observar precisamente o contrário:

«em qualquer assunto no qual a diferença de opinióes seja possível, a verdade depende de um equilíbrio a ser alcançado entre dois conjuntos de razóes conflituantes» (Mill, 1962: 163).

É este, afinal, o cenário que encontramos «quando nos viramos para assuntos infinitamente mais complicados, para a moral, para a religião, para a política, para as relaçóes sociais, e para os afazeres da vida» (Mill, 1962: 163). Este é um cenário que nos aponta para o pluralismo; um pluralismo que decorre não apenas da observaçáo do político, mas que se justifica pelo próprio interesse da verdade: «o interesse da verdade requer uma diversidade de opiniốes» (Mill, 1962: 179). Pois que, de acordo com Mill, «só através da diversidade de opinióes pode existir, no estado actual do intelecto humano, uma hipótese de fair-play para todos os lados da verdade» (Mill, 1962: 175-6). O pluralismo é, assim, um requisito elementar ao próprio processo do conhecimento e, por esta mesma razáo, torna-se um requisito elementar na busca da verdade.

Por outro lado, Mill não só não vê o conflito como uma ameaça à verdade, como nem sequer acredita, ingenuamente, que do conflito emergirá sempre a verdade. Em bom rigor, nada nesta lógica impede que o conflito não termine com o triunfo do erro. O que Mill sugere é que, se por um lado, o conflito de posições contrárias é endémico ao próprio processo de conhecimento, por outro, e em virtude da sua crença no progresso, Mill acredita que, ainda que determinado conflito resulte num desvio face à verdade, a prazo, e porque esse resultado será ele próprio permanentemente sujeito à confrontação com novas posiçôes, a aproximação à verdade, mesmo que temporariamente atrasada, retomará o seu curso ${ }^{44}$. Esta é, aliás, «a grande vantagem da verdade»:

«A grande vantagem da verdade consiste nisto, que quando uma opiniáo é verdadeira, ela pode ser extinta uma, duas ou muitas vezes mas, no decurso dos tempos, encontramos geralmente pessoas capazes de a redescobrir (...)» (Mill, 1962: 155).

Por isso mesmo é que, como já referimos, uma regra que esta reflexão não pode deixar de extrair é a de que as posiçóes adoptadas devem ser provisórias, precisamente por causa da natureza provisória do entendimento da verdade no decurso do processo de conhecimento. Ora, tal como no domínio epistemológico, a provisoriedade implica que determinada

$44 \mathrm{Ou}$, como o próprio Mill afirma: «À medida que a espécie humana melhora (improve), o número de doutrinas que não são mais disputadas ou postas em dúvida, crescerá constantemente: e o bem-estar da espécie humana quase poderá ser medido pelo número e gravidade das verdades que alcançaram o estatuto de se tornarem incontestadas» (Mill, 1962: 171). Porém, a "consolidaçấo da opinião» que este movimento envolve, embora possa ser «salutar» no caso das opiniōes verdadeiras, será "perigoso» no caso das opinióes erradas. E, precisamente, o problema está em que, como nunca nos podemos situar fora do processo de conhecimento, nunca poderemos afirmar, com certeza, se a consolidação da opinião é salutar ou perigosa. Não obstante, acreditamos que, de acordo com os princípios enunciados por Mill, a sua posição tenderia a inclinar-se para, por defeito, considerar uma tal consolidação como perigosa, o que o levará a nunca abandonar o entendimento do carácter provisório da verdade. 
posição que é tomada como verdadeira possa ser revista, também no domínio do político se entende, decorrentemente, que a adopção de quaisquer políticas não deverá deixar de contemplar a possibilidade de revisão. As políticas, tal como as etapas do processo de conhecimento, deverão então ser consideradas de forma provisória e reversível ${ }^{45}$. Esta regra decorre da ideia do permanente progresso do conhecimento humano, que assenta na capacidade de identificar o erro e assim, de forma tentativa e provisional, corrigir a posição anterior, num movimento perpétuo de aproximação à verdade. A incorporação do erro como característico e elementar do processo político é assim encarada de uma forma tão natural como aquela em que ele é concebido no processo do conhecimento. Como Mill diria, "uma qualidade da mente humana, a fonte de tudo o que é respeitável no homem, quer como ser intelectual, quer como ser moral, é que os seus erros são corrigíveis» (Mill, 1962: 146). Esta será uma característica inerente ao processo do conhecimento humano e, como tal, extensível aos produtos da razão humana, incluindo a política.

É neste sentido que a reflexão de Mill sobre a liberdade de expressão aconselha a uma verdadeira política de tolerância fundada na mais extensa possível exposição de argumentos e na mais profunda discussão dos mesmos. Isto é, uma prática de tolerância alicerçada num racionalismo crítico, porque anti-dogmático, na permanente discussão de pontos de vista, no constante confronto de opinióes acerca da verdade, que terá como consequência o aprofundamento do conhecimento e o decorrente progresso da humanidade. Uma política que convida, muito no espírito da fantasia de Vico, da Einfuhlung de Herder, ou mesmo da sympathy de Adam Smith, a que "cada um mergulhe na posição mental daqueles que dele diferem» (Mill, 1962: 163). Quem o fizer, não apenas conhecerá melhor a posição do outro, mas também a sua própria posição. Pois que,

«aquele que conhece apenas a sua versão do assunto, conhece-o pouco. As suas razôes poderão ser boas, e pode ninguém ter sido capaz de as refutar. Mas se ele for igualmente incapaz de refutar as posiçóes da posição contrária; se ele nem sequer souber em que consistem, ele não tem qualquer fundamento para preferir qualquer posição de entre ambas. A posição racional para ele seria uma suspensão do julgamento e, a não ser que ele se contente com isso, ele será levado, ou pela autoridade, ou adoptará, como a generalidade do mundo, a posição em relação à qual sinta maior inclinação» (Mill, 1962: 163).

45 É notável como a epistemologia de Stuart Mill prenuncia, em larga medida, o falibilismo que Karl Popper viria a desenvolver na sua Lógica da Descoberta Cientifica. Muito sinteticamente, este pode ser traduzido como a tese segundo a qual o conhecimento humano é falível porque essencialmente conjectural, pelo que, ironicamente, a aproximação à verdade é feita através de um processo contínuo de identificação, definição e afirmação dos erros. Neste sentido a verdade, cuja natureza náo poderá deixar de ser uma inter-subjectividade, terá sempre um estatuto provisório que decorre da sua sujeição permanente à possibilidade de refutação. Como Karl Popper sustentaria, a recusa de sujeitar o que quer que tomemos como verdade «à contestação honesta e vigorosa" não é mais que uma evidência de arrogância intelectual - essa sim, porque impeditiva do progresso e prejudicial à busca contínua da verdade, seria, aos olhos de Popper, intolerável. Como o próprio explicaria em The Poverty of Historicism:

«Este método pode ser usado, mais precisamente, com vista a buscarmos, e a combatermos contra, os maiores e mais urgentes males da sociedade, ao invés de procurarmos, e lutarmos por, algum bem último (como os holistas tendem a fazer). Mas, uma luta sistemática contra males definitivos, contra formas concretas de injustiça e de exploração, e sofrimentos evitáveis, como a pobreza ou o desemprego, é uma coisa muito diferente da tentativa de realizar um ideal e distante plano (blueprint) da sociedade» (Popper, 1974: 91). 
Isto é, para Mill, no plano epistemológico, o contrário do racionalismo crítico será a cedência ao irracionalismo (ou, pelo menos, a uma certa forma de emotivismo, entendido aqui como a submissão ao domínio das paixôes) ou à adopção de uma posição de racionalismo dogmático. No plano político, a alternativa à prática da tolerância, no respeito pela liberdade de expressão, levará ao relativismo e à arbitrariedade moral, ou ao autoritarismo e à anulação da Liberdade. É por isso mesmo que, tal como a «verdade depende de um equilíbrio», também a política dele depende.

\section{A Tolerância como condição do progresso humano}

O liberalismo de Mill traduz, afinal, uma profunda reacção individualista contra a interferência de terceiros na busca de cada um pela sua própria concepção do bem e da vida boa. É este o sentido em que se torna clara a defesa dos famosos «experiments in living». Estes dependem efectivamente da diversidade que resulta da natureza complexa que é atributo da humanidade mas são também, simultaneamente, a garantia da sobrevivência dessa mesma humanidade. É por isso que:

«A única liberdade merecedora do nome é a de prosseguirmos o nosso próprio bem à nossa própria maneira, conquanto não tentemos privar os outros das deles, ou impedir os seus esforços para as alcançarem» (Mill, 1962: 138).

Não surpreendentemente, assim considerada, a Liberdade não é mais que um sinónimo de tolerância. O que preocupa Mill é a garantia da possibilidade de cada um poder trilhar o seu próprio caminho, possibilidade essa que deve sempre ser equilibrada com a impossibilidade de obstruir os caminhos dos outros ${ }^{46}$. O que náo o preocupa é que todos os caminhos

46 É esta garantia que Glyn Morgan traduz como a segurança indispensável para «prosseguirmos o nosso próprio bem à nossa própria maneira», que estará verdadeiramente na base da justificação da liberdade em Stuart Mill, e que serve de guia para o enquadramento de uma política de tolerância. A prossecuçáo do nosso próprio bem à nossa própria maneira pressupóe que cada um disporá da segurança necessária para trilhar o seu próprio caminho. Porém, o texto do On Liberty não explora suficientemente esta questão da segurança, como, aliás, Glynn Morgan bem adverte. Será, portanto, necessário recorrer a outros textos de Stuart Mill, nomeadamente o Utilitarianism, para melhor compreendermos o seu significado. Aí poderemos, segundo Morgan, encontrar a afirmação clara da segurança como «o mais vital de todos os interesses»; aquele «do qual nenhum ser humano pode prescindir; e do qual toda a nossa imunidade face ao mal depende». A segurança será o elemento que nos permite perspectivar «o nosso próprio bem» no tempo, de forma continuada, conferindo sentido à própria noçáo de «seres em progresso». Sem ela, não poderíamos almejar a mais que a uma pobre "gratificação instantânea». Como Glyn Morgan bem sustenta: «A segurança também figura proeminentemente na noção de Mill de progresso e no seu entendimento de civilização. (...) a segurança envolve não meramente a segurança física imediata, de curto prazo, mas uma protecção durável, de longo prazo, da personalidade e da propriedade. $\mathrm{Na}$ ausência desta protecção, os indivíduos teriam apenas acesso momentâneo aos seus bens, eles nunca alcançariam a tranquilidade psicológica. Mais ainda, em sociedades inseguras os indivíduos seriam incapazes de poupar e planear o futuro. Mill vê a segurança (entendida desta forma extensiva) tanto como uma pré-condição como característica definitiva de uma sociedade civilizada».

Assim, continua o professor de Harvard: «O argumento de Mill sobre a liberdade repousa sobre a ideia segundo a qual o nosso interesse vital na segurança requer a emergência de um carácter progressivo, não meramente nuns poucos indivíduos, mas a uma escala societal». Essa é, afinal, a razão do sucesso das «sociedades liberais modernas»: "proteger todos os cidadãos em termos minimamente iguais contra as principais e evitáveis inseguranças da vida». Por isso mesmo, conclui Glyn Morgan: «só os interesses da segurança podem justificar a coerção.» (Morgan, 2008: 150, 151, 159, 162, 163; As citaçóes de Mill são referentes a Mill, 1963-1991: 250-1). 
trilhados sejam, por necessidade, os caminhos correctos ou verdadeiros. O que o preocupa, em suma, é a existência de uma pluralidade de caminhos.

Mas, note-se bem, o desejo de Mill de «proteger os dissidentes e os heréticos enquanto tal» não resulta meramente de uma concepção da liberdade individual sustentada por um princípio de reciprocidade simples. Em boa verdade, o seu alcance é muito maior. A protecção da liberdade individual não é estabelecida meramente em nome do interesse individual, mas do interesse comum. A preservação da «variedade é do interesse comum pois que é dela que depende o próprio processo e progresso do conhecimento humano. É esta a tese central de toda a segunda secção do On Liberty. Assim perspectivada, a liberdade não é uma consequência da escolha verdadeira; pelo contrário: a verdade é que poderá ser produto do exercício livre de escolhas. Em bom rigor, afastando a própria possibilidade do estabelecimento definitivo e unitário da verdade - ambição que considera sempre antitética com a garantia da liberdade individual -, Mill considera antes a liberdade como condição necessária ao próprio processo do conhecimento. Segundo Berlin:

«No centro do pensamento e do sentimento de Mill encontra-se, não o seu utilitarismo, nem a preocupação com o esclarecimento (enlightenment), nem com a separação do domínio privado do do público (...), mas a sua crença apaixonada de que os homens são tornados humanos pela sua capacidade para a escolha - escolha do bem e do mal igualmente. A falibilidade, o direito ao erro, como corolário da capacidade para o auto-melhoramento; a desconfiança da simetria e da finalidade como inimigas da liberdade - estes são os princípios que Mill nunca abandona. Ele permanece agudamente ciente do carácter multifacetado da verdade e da irredutível complexidade da vida, que descarta a própria possibilidade de qualquer solução simples, ou a ideia de uma resposta final para qualquer problema concreto» (Berlin, 1969: 192).

De acordo com o enfoque pluralista que Isaiah Berlin faz sobre o «pequeno grande livro» de Mill - na feliz expressão de Sir Richard Livingstone - a tolerância que devemos à expressão livre de cada indivíduo excede a lógica em que se funda o conceito de liberdade negativa em sentido estrito. Isto é, a esfera de liberdade individual deve ser assegurada não apenas por respeito ao interesse individual de cada um - ideia que está na base do chamado «harm principle» -, mas por respeito ao interesse geral da própria humanidade. Nas palavras de Mill:

Mas o mal peculiar do silenciamento da expressão de uma opinião é de se está a roubar a espécie humana; tanto a posteridade como a presente geração; aqueles que discordam da opiniẫo ainda mais que aqueles que a sustêm. Se a opiniấo estiver correcta, eles ficam privados da oportunidade de trocarem o erro pela verdade; se estiver errada, eles perdem, o que é quase um tão grande benefício, a percepção clara e a vivificante impressão da verdade, produzida pela sua colisão com o erro" (Mill, 1962: 142).

Assim, negando a possibilidade de nos afirmarmos na posse da verdade absoluta e, portanto, final, o que Mill afirma é que o nosso conhecimento é sempre imperfeito, incompleto, falível - ou, pelo menos, que, ainda que tenhamos realmente alcançado a verdade derradeira sobre qualquer assunto, nunca estaremos em condiçóes de o podermos assegurar com certeza, pondo assim um termo definitivo ao debate sobre esse mesmo assunto. E, como tal, qualquer expressão de opinião pode, em princípio, contribuir para o avanço do conhecimento humano - constituindo-se, como tal, em benefício geral. Assim, diz Mill: 
«Todo o silenciamento da discussão é uma assumpção de infalibilidade» (Mill, 1962: 143). Ora, a assumpção da falibilidade do conhecimento humano implica, obviamente, a afirmaçáo do carácter provisório da verdade. E esta convida ao concurso, quanto mais aberto possível, do maior número de contributos possíveis. Neste sentido, questiona Berlin: «Sem a infalibilidade como pode a verdade emergir senão através da discussão?» (Berlin, 1969: 186) O dever de tolerarmos aquilo que nos parece errado, ou meramente inútil, decorre, portanto, desta assumpção da falibilidade do conhecimento; e, o que é mais, do desejo de nos aproximarmos da verdade e de nos afastarmos do erro. Reforçando esta ideia acerca da natureza provisória do conhecimento, Mill afirma que:

«Existe a maior diferença entre presumir uma opiniáo como sendo verdadeira, porque com todas as oportunidades para a contestar, ela não foi refutada, e assumir a sua verdade com o propósito de não se permitir a sua refutação» (Mill, 1962: 145).

Podemos encontrar aqui um contraste essencial entre as ideias de tolerância e de intolerância. A primeira celebra o conhecimento como uma demanda permanente, como uma busca permanentemente inacabada da verdade, nunca tomada como definitiva mas sempre tentativa ou provisória, na qual a liberdade (de pensamento e de expressão) desempenha o papel fundamental de colocar este processo sobre o questionamento permanente. É neste sentido que melhor se compreende o papel essencial da tolerância, na medida em que, em prol desta demanda, todas as contribuiçôes - quantas mais, melhor - devem ser admitidas a concurso. Se reconhecermos que não sabemos de antemão o destino de todo este processo, então, teremos que admitir que o seu sucesso dependerá do maior número de avenidas que pudermos trilhar - mesmo o caminho que se revele infrutífero não deixará, também ele, de ter o seu préstimo, tal como num percurso rodoviário um sinal de beco sem saída tem o mérito de poupar ao condutor o incómodo de percorrer a totalidade do troço assinalado para só no final se aperceber que terá de regressar ao ponto de partida.

Pelo contrário, a segunda ideia, correspondente à de intolerância, tende a traduzir-se num fechamento da verdade. Pois que, «a menos que seja contraditada, a verdade arrisca-se a degenerar em dogma ou preconceito». (Berlin, 1969: 189) Não permitindo a sua refutação, o intolerante, embora talvez pretendendo fortalecer aquilo que toma como verdade, acaba por a enfraquecer, já que, não permitindo a liberdade de expressóes contrárias à sua, não permite sequer o robustecimento contínuo que eventualmente poderia decorrer caso conseguisse responder com sucesso às críticas que contra ela seriam desferidas. Mas, o mal maior é que, ao fazê-lo, o intolerante está a «roubar a espécie humana» (Mill, 1962: 189). Rouba-lhe a possibilidade de contribuir para o processo contínuo em que se desenrola o conhecimento humano.

Mill entende a autonomia individual, a capacidade de cada um se responsabilizar por si próprio, como degrau inicial para um estatuto de humanidade plena; e vê a espécie humana como sendo constituída por «seres em progresso», como uma espécie singularizada pelo seu poder criativo e caracterizada por um progresso permanente que é mantido sempre em aberto por uma busca interminável do conhecimento - conhecimento esse que é entendido como nunca encerrado e é orientado por uma busca da verdade que nunca poderá ser encerrável.

É nestes termos que, por um lado, Mill acredita no valor da liberdade individual e defende-o procurando limitar ao máximo a legitimidade da interferência externa na esfera 
do indivíduo. É também nestes termos que, por outro lado, Mill acredita que a condição básica para que a espécie humana, como um todo, progrida, é a da manutenção de um espaço de tolerância, tão alargado quanto possível, que encoraje o concurso do máximo de contribuiçóes possíveis com vista a esse propósito.

\section{Bibliografia:}

BERLIN, Isaiah, (1969), Four Essays on Liberty, Oxford, Oxford University Press.

HAYEK, Friederich A. von, (1991), The Road to Serfdom, London, Routledge, 1944, 1991.

MILL, John Stuart, (1962), On Liberty, in: Mary Warnock (Ed.), John Stuart Mill, Utilitarianism, London, Fontana Press.

MILL, John Stuart, (1963-1991), Utilitarianism in Collected Works of John Stuart Mill, John M. Robson (Ed.), Toronto, Toronto University Press.

MORGAN, Glyn, (2008), «The Mode and Limits of John Stuart Mill's Toleration» in: Melissa S. Williams and Jeremy Waldron, Toleration and Its Limits, New York and London, New York University Press, 139-167.

POPPER, Karl R., (1974), The Poverty of Historicism, London, Routledge \& Kegan Paul, 1957, 1974.

POPPER, Karl R., (2002), Unended Quest: An Intellectual Biography, London, Routledge, 1976, 2002.

WARNOCK, Mary, (2001), «The Limits of Toleration» in: Susan Mendus, David Edwards (Ed.s), On Toleration, Oxford, Oxford University Press. 


\section{John STUART Mill, \\ A «TiRANiA DA MAIORIA» E O SEU FUTURo}

Alexandre Franco de Sá

O livro On Liberty de John Stuart Mill, cuja publicação há cento e cinquenta anos comemoramos, constitui indubitavelmente, antes de mais, um marco fundamental na defesa social e política da Liberdade humana. Com a publicação de On Liberty, em 1859, o pensamento filosófico dava um passo essencial naquilo a que Fichte tinha chamado a «reivindicação da liberdade de pensar», estendendo-se para além da mera exigência de um poder político que, no seu exercício, soubesse ser limitado e tolerante. Vários pensadores, de Espinosa a Locke, de Voltaire a Kant, tinham defendido já, sob vários argumentos, a necessidade de o poder das magistraturas políticas não ser usado para a eliminação da liberdade individual dos homens, da sua liberdade de religião, de pensamento e de expressão, devendo, portanto, restringir-se e moderar-se a si mesmo no seu exercício. Destacando-se destes, Stuart Mill defenderá que a mera neutralidade política não é suficiente para o imprescindível reconhecimento do direito dos homens à Liberdade e que um tal reconhecimento não pode deixar de implicar, náo apenas uma atitude de tolerância por parte dos magistrados políticos relativamente às crenças, doutrinas e pensamentos de cada homem, mas também e sobretudo um empenho destes mesmos magistrados para que as circunstâncias da vida social não tornem, na prática, insuportável a sua expressão. Contudo, se $O n$ Liberty constitui um marco essencial no percurso do reconhecimento da Liberdade humana, dir-se-ia também que o modo como aqui se procede a este reconhecimento náo pode deixar de nos surgir hoje como caracterizado por limitaçóes intrínsecas. É o alcance da obra na tematização da questão da Liberdade, assim como as suas limitaçóes nesta tematização, que aqui procuraremos brevemente considerar.

Um primeiro aspecto que distingue On Liberty, na sua tematização da Liberdade humana, encontra-se na clareza e coerência com que na obra é enunciada a sua tese fundamental. Esta tese repousa na afirmação de um princípio absolutamente claro, transparente e inequívoco para que a esfera da liberdade individual seja separada do campo de possibilidades de uma intervenção legítima por parte de qualquer poder exterior. Stuart Mill enuncia um tal princípio determinante da esfera de uma liberdade individual inviolável e irredutível nos seguintes termos:

«Este princípio é o de que o único fim para o qual a humanidade está autorizada, individual ou colectivamente, a interferir na liberdade de acção de qualquer um dos seus, é a autoprotecção. Que o único propósito para o qual o poder pode ser legitimamente exercido sobre qualquer membro de uma comunidade civilizada, contra a sua vontade, é o de evitar danos para os outros. O seu próprio bem, seja físico ou moral, não é suficiente como autorização. [...] Na parte que meramente lhe concerne, a sua independência é, de direito, absoluta. Sobre ele mesmo, sobre o seu próprio corpo e mente, o indivíduo é soberano» (Mill, 1998: 14).

Assim, segundo o princípio enunciado por Mill, dir-se-ia que um indivíduo, uma vez adulto e em condiçóes normais de desenvolvimento, apenas poderia ser limitado na sua 
liberdade - na livre expressão e na livre vivência das suas crenças, dos seus pensamentos, dos seus hábitos e dos seus gostos - se essa mesma liberdade se constituísse como nociva para os outros. O enunciado por Mill do princípio da liberdade individual baseia-se, então, poderse-ia dizer, na distinção clara e inequívoca de dois tipos de acçôes e de opiniốes. No caso de acçóes e mesmo de opiniốes individuais que conduziriam a acçóes nocivas para terceiros, os magistrados políticos e a sociedade poderiam e deveriam intervir legitimamente no sentido de restringir ou mesmo anular essas acçôes, assim como de impedir a expressão pública de opinióes que a elas conduzissem. Contudo, no caso em que uma acçáo teria influência apenas na vida do indivíduo que a praticasse, e na circunstância em que a expressão de uma opinião não teria efeitos senão na existência do indivíduo que a professasse, esta acção e esta opinião deveriam ser essencialmente livres, sendo deixadas indeterminadas por instâncias públicas e sociais. Como conclui Stuart Mill:

«Ninguém pretende que as acçôes deveriam ser tão livres quanto as opiniōes. Pelo contrário, mesmo as opiniốes perdem a sua imunidade, se as circunstâncias nas quais são expressas são tais que a sua expressão constituiria uma instigação positiva a algum acto maldoso. [...] A liberdade do indivíduo deve ser muito limitada; ele não pode tornar-se nocivo para outros. Mas se evitar molestar os outros naquilo que lhes concerne, e se agir meramente de acordo com a sua inclinação e juízo em coisas que lhe concernem, as mesmas razóes que mostram que a opinião deve ser livre provam também que lhe devia ser permitido, sem ser molestado, às suas próprias custas, levar as suas opiniôes à prática» (Mill, 1998: 62-63).

Se On Liberty se distingue, antes de mais, pela clareza do enunciado do princípio de que parte, a fundamentaçáo deste princípio constitui um segundo aspecto essencial pelo qual a obra pode ser destacada como um marco fundamental na defesa da Liberdade humana. A defesa de que os homens deveriam ser, em assuntos que só afectariam a sua individualidade, essencialmente livres, indeterminados por quaisquer poderes exteriores, justifica-se para Stuart Mill, antes de mais, pela evocação da condição finita e falível do homem. É a evocação desta falibilidade como marca fundamental da natureza humana, afirmada por Stuart Mill com a clareza possível diante das teses utilitaristas de Jeremy Bentham e do seu pai James Mill, que lhe permite a conclusão não só de que não é possível a um homem estar absolutamente certo e seguro de se encontrar na posse de uma verdade absoluta e definitiva, mas também de que, mesmo havendo por parte desse mesmo homem uma tal convicção, esta não poderia constituir uma justificaçáo suficiente para que ele forçasse outros homens a aceitarem essa mesma verdade. Como escreve Mill:

«Não é o sentir-se seguro de uma doutrina (seja ela qual for) aquilo a que chamo uma assunção de infalibilidade. É propor-se decidir essa questão pelos outros, sem lhes permitir ouvirem o que pode ser dito do lado contrário. E não denuncio nem reprovo menos essa pretensão se ela for reivindicada do lado das minhas mais solenes convicçôes» (Mill, 1998: 28).

O argumento esboçado por Stuart Mill na defesa de que a convicção de um homem sobre a sua verdade náo o justifica na sua eventual tentativa de a impor aos outros homens é aqui decisivo. Este argumento tem dois lados que importa diferenciar e tornar explícitos. Por um lado, a tentativa de impor aos outros uma verdade corresponderia, segundo Mill, a uma concepção da natureza humana na qual o homem seria considerado como um ente 
determinado por um fim pré-estabelecido, invariável e apreensível cientificamente. Diante de uma tal determinação do homem por um fim que escapa à sua liberdade, determinaçáo essa pela qual seria possível a pretensáo de constituir um modelo de comportamento previsível, assim como uma educação totalmente programável e uma ética cientificamente fundada, Mill afirma claramente:

«A natureza humana não é uma máquina a ser construída de acordo com um modelo, e montada para fazer exactamente o trabalho que lhe é prescrito, mas uma árvore que requer crescer e desenvolver-se para todos os lados, de acordo com a tendência e as forças interiores que fazem dela uma coisa viva» (Mill, 1998: 66).

Contudo, por outro lado, mais do que pressupor uma visão redutora da natureza humana, a tentativa de impor aos outros uma verdade tida por absoluta, na medida em que corresponderia à pura e simples eliminação de qualquer juízo crítico e de qualquer confrontação dessa verdade com verdades alternativas, corresponderia igualmente ao enfraquecimento da própria verdade que se pretenderia impor. É então em função da própria conservação da verdade como verdade viva e actuante na existência humana que, para Stuart Mill, a liberdade de expressão de uma opinião falsa deveria ser garantida. Neste sentido, Mill afirma claramente:

"Mesmo que uma opinião recebida seja não apenas verdadeira, mas toda a verdade; a não ser que ela seja, e seja actualmente, contestada vigorosa e honestamente, ela será mantida, por muitos dos que a recebem, à maneira de um preconceito, com pouca compreensão ou sentimento dos seus fundamentos racionais. E não apenas isso, mas o significado da própria doutrina correrá o risco de ser perdido, ou enfraquecido, e privado do seu efeito vital no carácter e na conduta: tornando-se o dogma uma mera profissão de fé formal, ineficaz para o bem, mas tapando o fundamento, e impedindo o crescimento de qualquer convicçáo real e sentida a partir da razão e da experiência pessoal» (Mill, 1998: 59).

Este último lado do argumento esboçado por Stuart Mill é decisivo, na medida em que é ele que mais plenamente revela o alcance da sua reivindicação de um direito do indivíduo humano falível à liberdade. Um tal argumento não discute se é possível ou não a um qualquer indivíduo, honesta e autenticamente convicto do carácter absoluto de uma verdade, estar efectivamente na posse de uma verdade absoluta. Independentemente do carácter ilusório que uma tal convicção possa oferecer, em virtude da falibilidade constitutiva da natureza humana, o que aqui está em causa, para Mill, não é o conteúdo dessa mesma verdade, mas o modo como esta é vivida por aquele que a proclama como tal. Segundo Mill, mais do que impedir o acesso a uma verdade absoluta, acesso esse que, sendo problemático, também não poderá ser proclamado como intrínseca ou constitutivamente impossível, o que a falibilidade humana determina consiste no facto de uma verdade náo poder deixar de ser afectada pelo modo como é assumida pelo homem que a proclama. Assim, segundo Mill, uma verdade imposta dogmaticamente e aceite acriticamente através da eliminação de qualquer confrontação com verdades alternativas, ainda que seja em si mesma uma verdade "verdadeira», e "verdadeira" em termos absolutos, perder-se-á fatalmente, com o passar do tempo, na força da sua convicção, e adquirirá crescentemente o estatuto de um mero dogma exterior à vida. Tal quer dizer que, para Mill, o valor de uma verdade não se esgota no seu eventual conteúdo verdadeiro, mas repousa, para além deste, no grau de crítica e de 
liberdade com que este conteúdo é proclamado. Poder-se-ia até dizer que, para Mill, desde que não resulte numa violaçáo da Liberdade e dos direitos de terceiros, um erro proclamado crítica e autenticamente, correspondendo a uma convicção genuína, valeria mais e seria pelo menos tấo digno de ser expresso livremente quanto uma verdade desvitalizada que fosse professada mecanicamente como um dogma exterior, alheio à vida na sua efectividade.

Esta subordinaçáo do valor de uma verdade ao modo como esta verdade é vivida e assumida é, então, o elemento fundamental que permite associar a defesa da Liberdade por Stuart Mill a uma posição política particular. Dir-se-ia que, para Mill, a defesa da Liberdade se orienta politicamente para a meta da formação de homens críticos e tolerantes, dispostos a subordinar as suas convicçóes próprias ao exame da crítica, abertos a escutar os outros e mesmo a ser persuadidos pelas suas razóes, da mesma forma que capazes de defender as suas próprias convicçóes com razoabilidade e sem dogmatismos diante destas mesmas razóes. Para Mill, a defesa de que cada um possa ser tal como a sua individualidade exige, expressando nos mais variados domínios, as características dessa mesma individualidade, está orientada não propriamente para aumentar a verdade e diminuir o erro no seio da sociedade, isto é, não propriamente para multiplicar o número de indivíduos que professam doutrinas verdadeiras, mas para aumentar o número de indivíduos que, independentemente do conteúdo das doutrinas que professam, o fazem de um modo crítico, tolerante, aberto e inteligente, assumindo as suas convicçóes e pensamentos, gostos e sentimentos, pelo facto de serem autenticamente seus e não por corresponderem às convicçóes, pensamentos, gostos e sentimentos da «maioria moral» presente na sociedade. É para expressar que o fim da formação dos homens deveria consistir não na sua uniformização doutrinal, mas precisamente no livre desenvolvimento das suas vocaçôes e tendências individuais, que Stuart Mill evoca aqui o conceito de "génio» como expressão de uma meta implícita da formação humana. Longe de ser determinado por um conteúdo comum e uniforme, o génio é precisamente aquela figura humana que se constitui como radicalmente singular no seu modo de ser. E é sob a referência implícita à necessidade política de alimentar e cultivar uma educação que tenha a singularidade do génio como ideia reguladora que Mill escreve:

«As pessoas de génio, é verdade, são, e deverão sempre ser, uma pequena minoria; mas para as ter, é preciso preservar o solo no qual crescem. O génio só pode respirar livremente numa atmosfera de liberdade. As pessoas de génio são, ex vi termini, mais individuais que quaisquer outras - menos capazes, consequentemente, de se adequar, sem uma compressão dolorosa, a qualquer um dos pequenos moldes que a sociedade providencia para poupar aos seus membros o trabalho de formar o seu próprio carácter» (Mill, 1998: 72).

Nesta alusão à necessidade política de cultivar socialmente um génio singularizante, a análise de Mill desenvolve-se, por outro lado, num duplo momento que deve também ser diferenciado. Em primeiro lugar, ela procede a um diagnóstico da sociedade do seu tempo, enraizando-se nele e mostrando como uma tal sociedade se caracteriza, nas suas práticas, por coarctar a liberdade individual. Em segundo lugar, ela procura enfrentar um tal diagnóstico e responder à falta de liberdade que denuncia.

Assim, por um lado, é reflectindo sobre o ambiente social em que se encontra que Stuart Mill o caracteriza como uma «mediocridade colectiva». Segundo Mill, a atmosfera social da sociedade sua contemporânea seria marcada precisamente pela tendência para uma tal normalização massificadora da vida humana, traduzida na valorização social de todo um conjunto 
de práticas e discursos homogeneizadores. Ao caracterizar uma tal atmosfera, Mill oferece, aliás, um retrato muito eloquente, que é interessante aqui reproduzir na íntegra:

«Presentemente, os indivíduos estão perdidos na multidão. Em política, é quase uma trivialidade dizer que a opinião pública governa agora o mundo. $\mathrm{O}$ único poder que merece esse nome é o das massas, e o dos governos enquanto se convertem a eles mesmos no órgão das tendências e instintos das massas. [...] Parece, contudo, que quando as opinióes das massas de homens meramente medianos se tornaram ou estão a tornar em todo o lado o poder dominante, o contrapeso e o correctivo dessa tendência seria a cada vez mais pronunciada individualidade daqueles que estão nas mais altas eminências do pensamento. Nestas circunstâncias, é muito especial que os indivíduos excepcionais, em vez de serem impedidos, sejam encorajados a agir diferentemente da massa. Em outros tempos, não haveria vantagem em eles o serem, a não ser que agissem não apenas diferentemente, mas melhor. Nesta Era, o mero exemplo da nãoconformidade, a mera recusa em dobrar o joelho ao costume, é ele mesmo um serviço. Precisamente porque a tirania da opiniáo é de tal modo a fazer da excentricidade algo reprovável, é desejável, de maneira a quebrar tal tirania, que as pessoas sejam excêntricas» (Mill, 1998: 74).

E é então nesta leitura da sua contemporaneidade, assim como no papel que nela desempenha uma "mediocridade colectiva», que Mill encontra, por outro lado, o fundamento último para a sua proposta política essencial: a proposta de que, longe de se limitar a não interferir na esfera da sociedade, a tarefa legislativa do poder político deveria interferir nela no sentido de impedir que essa mesma sociedade, na sua maioria moral, se constituísse como um impedimento para a livre expressão da individualidade de cada um.

Assim, segundo Mill, para a defesa da liberdade individual de cada um, não bastaria reivindicar que o Estado reconhecesse na esfera privada dos cidadãos um domínio de liberdade que deveria permanecer vedado à possibilidade da sua intervenção política, do mesmo modo que não seria suficiente que o Estado fosse representativo ou democrático, assumindo junto do governo uma instância parlamentar que estaria incumbida de representar a sociedade junto do Estado. Mais do que um Estado circunscrito e limitado diante da esfera privada dos cidadãos, ou mais do que um governo democrático que reconhecesse a soberania do povo, ou pelo menos a necessidade da sua subordinação a instituiçóes representativas desse mesmo povo, a Liberdade exigiria que o Estado fosse determinado por regras e leis destinadas a impedir a própria sociedade, na sua maioria moral, de discriminar indivíduos excêntricos ou de proibir-lhes a livre expressão das suas doutrinas e dos seus pensamentos, das suas opinióes e dos seus gostos minoritários, desde que tais doutrinas, pensamentos, opinióes e gostos dissessem respeito apenas à sua individualidade, ou seja, desde que, independentemente da repulsa que pudessem causar na maioria dos seus concidadãos, não se constituíssem como nocivos para a vida destes. Face à tendência democrática para encontrar nos consensos ou nas maiorias um critério para a verdade e a correcção, Mill manifesta assim as maiores reservas quanto a conceitos democráticos como «soberania do povo» e «vontade geral»:

«A vontade do povo quer dizer, na prática, a vontade da parte do povo mais numerosa ou mais activa; a maioria, ou aqueles que são bem sucedidos em fazerem-se aceitar como a maioria; o povo, consequentemente, pode desejar oprimir uma parte do seu número; e é preciso tantas precauçôes contra isso como contra qualquer outro abuso de poder» (Mill, 1998: 8). 
E é, então, essencialmente diante da representação de uma «tirania da maioria» que toda a obra se articula, ganhando consistência como um manifesto em defesa da liberdade individual face aos costumes e hábitos das massas, ou face aos pensamentos e gostos impostos pela maioria dos homens presentes na sociedade. O fio condutor de On Liberty é, por isso, apresentado por Stuart Mill desde o início da obra:

«Tal como outras tiranias, a tirania da maioria foi a princípio, e ainda é vulgarmente, mantida através do medo, operando sobretudo através dos actos das autoridades públicas. Contudo, reflectindo, as pessoas perceberam que quando a sociedade é ela mesma o tirano - a sociedade colectivamente, acima dos indivíduos separados que a compóem - os seus meios de tiranizar não são restritos aos actos que ela pode fazer pelas mãos dos seus funcionários políticos. A sociedade pode executar, e executa de facto, os seus próprios mandatos: e se ela estabelece mandatos errados e náo certos, ou quaisquer mandatos em coisas nas quais não se deveria intrometer, ela pratica uma tirania social mais formidável do que qualquer tipo de opressão política, na medida em que, embora náo sustentada usualmente por tais penalidades extremas, deixa menos meios de escape, penetrando muito mais profundamente nos detalhes da vida e escravizando a própria alma» (Mill, 1998: 8-9).

A concepção de uma tirania da maioria diante da qual seria necessário guardar a Liberdade dos homens, ou seja, a concepção de que o maior perigo para esta Liberdade se encontra já não tanto num despotismo do Estado e do governo como numa tirania simultaneamente mais discreta e mais poderosa - porque exercida por meios mais subtis do que a coerção violenta que se encerra num uso explícito da força - é então a concepção que mais claramente marca o alcance e a originalidade da reflexáo desenvolvida por Mill em torno da Liberdade. No entanto, importa notar também que, ao mesmo tempo que marca maximamente este alcance e esta originalidade, a concepção de uma tirania da maioria assinala também ao pensamento desenvolvido por Mill os seus mais claros limites, na medida em que a apresentação que deste conceito é feita permanece encerrada no século XIX, subtraindo-se inteiramente, nessa medida, à antecipação do desenvolvimento que ele terá no século posterior. Daí que Isaiah Berlin, em John Stuart Mill and the Ends of Life, num texto que há cinquenta anos comemorava o centenário da publicaçáo de On Liberty, tenha razão quando nota:

«Mill não tinha quase nenhum dote profético. Ao contrário dos seus contemporâneos Marx, Burckhardt, Tocqueville, ele não tinha nenhuma visão daquilo que o século xx traria, nem das consequências políticas e sociais da industrialização, nem da descoberta da força dos factores irracionais e inconscientes no comportamento humano, nem das técnicas aterradoras para as quais este conhecimento conduziu e está a conduzir» (Berlin, 2004: 227-228).

Na medida em que a análise de Mill ficou encerrada na representação da tirania da sociedade sobre a liberdade individual como uma simples coerção social do vulgo, ela ignorou que, no século $\mathrm{XX}$, o futuro de uma tal tirania social consistiria precisamente na atribuição a minorias sociais politicamente activas e crescentemente mobilizadas do papel homogeneizador, nivelador e normalizador que Mill não podia ainda deixar de encarar como o atributo inevitável de uma maioria moral instalada socialmente. Dir-se-ia que, em larga medida, o século XX é constituído pela transformação da tirania social de uma maioria 
moral, diante da qual Mill reivindica o direito à liberdade individual, na tirania de minorias sociais que, mobilizadas pelo projecto de uma transformação mais ou menos radical da própria sociedade, se propóem transformar os homens individuais nela presentes através de uma determinaçáo das suas opinióes, dos seus pensamentos e mesmo da sua sensibilidade por meio de técnicas muito mais invasivas, em relação à liberdade individual de cada um, do que a simples coerção social dos costumes poderia alguma vez ter esperado realizar. E é, então, no enquadramento desta transformação da tirania social da maioria - com a qual On Liberty se confronta - em várias formas, mais ou menos subtis, de tirania social de minorias, características da história do século XX, que a reflexão de Mill adquire a sua possível actualidade. Trata-se de saber de que forma é possível dirigir os argumentos de Mill em favor da liberdade individual, diante da tirania social dos costumes aceites pela maior parte de uma população, contra as tentativas posteriores de submeter essa mesma liberdade individual à acção de técnicas de normalização da opinião, do pensamento e da sensibilidade utilizadas por minorias sociais mobilizadas para a transformação da própria sociedade. Um tal «uso» do pensamento de Mill é possível, mas não pode ignorar que os dois conceitos de «tirania da maioria» e de "tirania de minorias» têm graus de complexidade diferentes. Se a concepção de uma "tirania da maioria» é algo inequívoco, e se a representação da coerção moral dos indivíduos por parte dos costumes de amplas maiorias sociais é algo fácil de determinar, já a concepção de uma «tirania de minorias» abrange a possibilidade de configuraçôes muito diversificadas que não são pacificamente reconduzíveis a uma estrutura comum.

Foi sobretudo a partir da década de 1920 que pensadores como Edward Bernays chamaram a atenção para o imparável desenvolvimento de técnicas conducentes a uma crescente determinação da "opiniấo pública» da grande maioria da população, assim como da vontade e dos afectos das «massas», por uma "elite» minoritária capaz ou de dominar essas mesmas técnicas ou de controlar política e economicamente o seu uso. Dir-se-ia, então, que, no século XX, a passagem da tirania da maioria para a tirania de minorias pode ser analisada, antes de mais, a partir da emergência do fenómeno da propaganda, em todas as suas configuraçóes e áreas específicas, desde a esfera política à económica. Como escreve Bernays:

«Independentemente da atitude que se escolha face a esta condição, permanece um facto que em quase cada acto das nossas vidas diárias, seja na esfera da política ou dos negócios, na nossa conduta social ou no nosso pensamento ético, somos dominados pelo relativamente pequeno número de pessoas que compreendem os processos mentais e os padrôes sociais das massas» (Bernays, 2005: 37-38).

É, então, a associação entre a propaganda e o exercício do poder, em todas as suas dimensôes e esferas, associação característica do século XX, que torna, à partida, ultrapassada a relação simples estabelecida por Mill entre uma tirania exercida pelos costumes da maioria e uma liberdade individual que não poderia deixar de ser, diante dela, politicamente protegida. A partir do século XX, poder-se-ia dizer que esta relação entre a tirania da maioria e a liberdade individual, tal como Mill a aborda no século XIX, não propriamente desaparece, mas transforma-se de um modo radical, na medida em que a tirania da maioria se converte cada vez mais na tirania de minorias que, através de técnicas de propaganda crescentemente sofisticadas, configuram a própria maioria de acordo com as suas representaçôes, isto é, moldam e formam a própria maioria nos seus pensamentos, desejos e sentimentos através de técnicas que progressivamente a despojam de qualquer característica genuína. 
Foi a emergência da propaganda, no seu uso específico como propaganda política, que esteve subjacente às grandes revoluçóes totalitárias no século XX, nas quais minorias partidárias, considerando-se a si mesmas esclarecidas e fazendo uso de técnicas cada vez mais penetrantes e subtis, procuraram transformar radicalmente a sociedade através de uma acção directa sobre a mente e o coração dos homens individuais, configurando o seu modo de pensar e de sentir, a representação do seu passado e do seu futuro, na medida em que nenhuma parte da vida destes mesmos homens, por mais ínfima que fosse, deveria conseguir furtar-se ao poder da sua intervenção. É essencialmente esta configuração da totalidade dos aspectos da vida humana por um poder que a constitui como vida totalmente exposta a esse mesmo poder que se encontra na base originária do conceito de totalitarismo. Através da exposiçáo total da vida individual à propaganda exercida pelo poder totalitário de uma minoria, este mesmo poder sustenta-se na promoçáo, no seio da maioria ou das massas, de uma representação da sua identidade presente e da sua história passada, ou seja, numa obra de «engenharia social» cujo sentido último consiste em deste modo - para usar a expressão de George Orwell - controlar o futuro e perpetuar o poder. Assim, o despojamento da capacidade de ensaiar algo novo, ou sequer de pensar em qualquer futuro alternativo, não poderia deixar de ser a consequência última inevitável do poder sobre o indivíduo exercido não por costumes sedimentados numa experiência de vida em comum ou por tradiçóes há muito enraizadas na vida social, mas pelas acçôes de intenção libertadora de minorias que, concebendo-se a si mesmas como "esclarecidas», exerceriam o seu poder através da propaganda. Como escreve Hannah Arendt acerca da manipulação do passado pela propaganda destas minorias:

«Se o passado e o presente forem tratados como partes do futuro - isto é, reconduzidos para o seu anterior estado de potencialidade - a esfera política é privada não só da sua principal força estabilizadora, mas do ponto inicial a partir do qual se pode mudar, começar algo novo. Aquilo que então começa é a mudança constante e o arrastamento numa completa esterilidade que são características de muitas novas naçôes que têm a má sorte de nascerem numa era da propaganda» (Arendt, 1993: 258).

No entanto, se a substituição da tirania da maioria pela tirania de minorias se manifesta, antes de mais, na emergência das experiências políticas totalitárias do século XX, interessa ter em conta que um tal fenómeno está longe de se esgotar nestas mesmas experiências. E é precisamente para o carácter abrangente e multifacetado deste fenómeno que as reflexôes de Mill apontam, no momento em que reflectem em torno da aniquilação da originalidade dos indivíduos singulares não pela acção política dos governos e das magistraturas, mas pelos hábitos, pelos costumes, pelos preconceitos e perspectivas morais partilhadas pela maioria da gente vulgar numa sociedade. Através do fenómeno da propaganda, e através da mobilização da sociedade por minorias fortemente empenhadas na sua transformação radical, o século XX vê despontar formas de subordinação do indivíduo à sociedade que certamente não se podem limitar à violência explícita do exercício do poder político. Em vez de se reduzirem a tais fenómenos políticos extremos, dir-se-ia que estas formas de subordinação da singularidade dos indivíduos à acção homogeneizadora de «elites» pretensamente iluminadas, que se interpretam como mais livres, mais esclarecidas e mais modernas naquilo a que Christopher Lasch chamou uma «revolta das elites», estão presentes mesmo em sociedades democráticas e liberais. Lasch fala de uma «revolta das elites» em explícita contraposição à abordagem por Ortega 
y Gasset, na primeira metade do século XX, de uma «rebeliáo das massas» (Lasch, 1996: 25), mostrando que, no final deste século, se trata já não tanto da determinação do indivíduo pelos preconceitos morais do vulgo, ou da sua indiferenciação em relação à massa, mas da mobilização da própria massa por «elites» que exercem o seu poder através dela, embora sem com ela se confundirem. É justamente a omnipresença desta subordinação do indivíduo a massas formadas e mobilizadas por elites pretensamente iluminadas que pode permitir compreender, ao longo do século XX, toda uma reflexão em torno do modo como uma sociedade agitada pelo ímpeto de uma transformação social rápida e constante não pode deixar de hostilizar a originalidade singular e o pensamento livre.

Um exemplo desta reflexão encontra-se no pensamento de Leo Strauss, cuja alusão à necessidade de um renascimento da filosofia política clássica talvez encontre aqui, em última análise, o seu fundamento inconfessado. Se a transformação da sociedade por minorias militantes teria necessariamente de resultar numa crescente hostilização social de qualquer pensamento delas divergente, a filosofia, enquanto questionamento sempre radical e subversivo, não poderia deixar de ser intrinsecamente hostilizada pela própria sociedade. Seria nessa medida que a filosofia requereria, segundo Strauss, o cultivo de uma escrita esotérica: uma escrita capaz de expressar entre linhas, de um modo socialmente tolerável, um pensamento que se subtrai sempre aos padrôes estritos daquilo que é politicamente consentido. É então a partir da experiência da sociedade sua contemporânea, marcada pela agitação da propaganda de elites iluminadas, que Strauss parte do princípio de uma incompatibilidade fundamental entre filosofia e sociedade, de uma hostilidade essencial desta em relação àquela, procurando encontrar na atitude dos autores clássicos o testemunho mais explícito da sua própria experiência. É neste sentido que ele pode descrever a atitude dos filósofos políticos clássicos, que se trataria de reavivar na contemporaneidade, do seguinte modo:

«Eles acreditavam que o fosso que separava «o sábio» e «o vulgo» era um facto básico da natureza humana que não poderia ser influenciado por qualquer progresso da educação popular: a filosofia, ou ciência, era essencialmente um privilégio «dos poucos». Eles estavam convencidos de que a filosofia enquanto tal era suspeita para e era odiada pela maioria dos homens» (Strauss, 1988: 34).

Do mesmo modo, é a ideia desta intrínseca hostilidade da maioria mobilizada pela minoria militante em relação a toda a singularidade original que se expressa nas reflexões de Walter Lippmann, em 1955, em torno da necessidade da «renovação» de uma «filosofia pública», diante de um poder que ele mesmo tinha analisado, em 1922, como uma capacidade propagandística de, junto da maioria do público, «manufacturar o consenso» ou "criar o consenso» (Lippmann, 1997: 158). Segundo Lippmann, uma tal filosofia pública, que deveria tentar contrariar a tirania de minorias actuantes através da propaganda, não poderia deixar de consistir numa recuperação pela vida pública das sociedades modernas de um conjunto de "tradiçóes» cujo cultivo, longe de escravizar a alma individual, seria precisamente a condição da sua liberdade. Como escreve Lippmann:

«De um modo crescente, as pessoas sáo alienadas dos princípios interiores das suas instituições. A questão é se e como esta alienação pode ser ultrapassada, e a ruptura das tradições de civilidade reparada. [...] A questão premente é se e, se assim for, como os homens modernos poderão estabelecer um contacto vital com as tradiçóes perdidas da civilidade» (Lippmann, 1955: 80). 
Reflexôes tão diferentes como as de Walter Lippmann ou de Leo Strauss, evocando desde a recuperação pela sociedade das suas «tradiçóes de civilidade», perdidas às mãos da sua mobilização pela propaganda, até à "escrita esotérica» da filosofia face a uma hostilidade intrínseca e essencialmente constitutiva dessa mesma sociedade, ou seja, reflexôes tão diferentes em torno da transformação da sociedade numa instância crescentemente hostil ao pensamento livre e à diferença, mesmo quando tal diferença é proclamada como um princípio, indicam que a substituição da tirania da maioria evocada por Mill pela tirania de minorias mobilizadas e militantes se constitui como um fenómeno generalizado, transversal e crescente ao longo do século XX. Reflectindo sobre a sua transversalidade crescente, poder-se-ia dizer até que ele é hoje generalizado também no início do século XXI. Assim, dir-se-ia que, nas sociedades democráticas e liberais, a emergência de minorias sociais mobilizadoras se configurou - e se configura ainda hoje - através de fenómenos muito variados, cada vez mais diversos e sofisticados, mas que reproduzem, no essencial, a mesma estrutura de relação de poder, segundo a qual uma minoria social, concebendo-se como uma minoria esclarecida, ou seja, representando-se e apresentando-se a si mesma, implícita ou explicitamente, como a antecipação do que deverá ser o futuro, procura transformar aceleradamente a sociedade no sentido do advento deste mesmo futuro.

$\mathrm{Na}$ segunda metade do século XX, foi esta estrutura que se reproduziu, por exemplo, nas grandes revoltas estudantis soixante-huitards e nos seus sucedâneos simbólicos europeus e americanos, no momento em que a minoria pertencente a uma geraçáo, impondo-se socialmente, inaugurou um projecto de conformação de toda a sociedade não apenas a um modo comum de pensar, mas a uma «visão do mundo» e a uma sensibilidade padronizadas, caracterizadas pela rejeição do peso das tradiçôes e dos "cânones totalitários» do passado. Como escreveu Élisabeth Lévy, num livro em que analisa as consequências deste movimento na cultura francesa contemporânea:

«Alguns habitantes mais ou menos ilustres da soixantehuitardie estão doravante fundamentalmente convencidos de que tudo aquilo que releva do passado é condenável em bloco. Eles pensam sinceramente ter libertado o mundo das antigas opressôes. [...] Somos para sempre jovens e temos razão em tudo, afirmam os adolescentes de cabelos grisalhos que, à cabeça dos media e das empresas - os verdadeiros lugares do poder -, impóem os seus valores e os seus interesses ao conjunto da sociedade» (Lévy, 2002: 375).

Do mesmo modo, é também a partir desta estrutura de poder que pode ser compreendida a actual tendência da política europeia para actuar de um modo terapêutico junto de tradiçóes, "visóes do mundo» ou práticas sociais consideradas como resíduos de um passado obscuro e preconceituoso, assim como a crescente inclinação de muitos Estados europeus para se constituírem como "Estados terapêuticos», que não hesitam em proibir a ostentação pública de símbolos religiosos considerados opressores ou chocantes, ou em criminalizar a expressão de opiniôes consideradas indecentes, ofensivas para a «memória histórica» e reveladoras de uma insensibilidade patológica. Como escreve Paul Edward Gottfried: «A ideologia terapêutica reinante requer que a maioria da populaçáo do Ocidente trabalhe para se livrar das taras da sua história ancestral» (Gottfried, 2002: 141).

No começo do século XXI, é também a estrutura de poder de minorias mobilizadas por esta «ideologia terapêutica» que se manifesta nos próprios centros de formação e de transmissão do saber e da cultura, sobretudo nas universidades, no momento em que as 
«humanidades» nelas cultivadas, colocadas ao serviço de "políticas de sensibilização", muitas vezes se convertem em instrumentos edificantes de padronização moral, de correcção política e de transformação social. Nos Estados Unidos, Roger Kimball levou a cabo uma provocadora mas lúcida análise deste processo:

"Quando os filhos dos anos sessenta receberam as suas cátedras e reitorados, não abandonaram o sonho da transformação cultural radical; foram implementá-lo. Agora, em vez de perturbar as aulas, estão a dar aulas; em vez de tentar destruir fisicamente as nossas instituiçôes educativas, estão a subvertê-las por dentro» (Kimball, 1998: 191-192).

A tendência crescente para a transformação da escola em geral, e das universidades em particular, em instrumentos de padronização social, numa normalização da sensibilidade que se estende desde o controlo do pensamento pela political correcteness até à vigilância do discurso por meio de speech codes, é hoje porventura a mais alarmante manifestação da substituição daquilo que Mill pensou como a tirania da maioria, na sua relação com a liberdade individual, pelo poder de minorias comprometidas com uma acção transformadora, homogeneizadora e sensibilizadora que se exerce de modo cada vez mais difuso e variado. Tendo em conta a proliferação de fenómenos desta natureza, uma reflexão sobre $\mathrm{On} L i$ berty, e sobre os seus argumentos em defesa da liberdade individual, poderá certamente contribuir para uma confrontação crítica, séria e profunda com estes mesmos fenómenos, surpreendendo neles, apesar das suas diferenças e da sua pluralidade, os traços de uma estrutura comum.

\section{Bibliografia}

ARENDT, Hannah (1993), Between Past and Future, New York, Penguin Books. BERLIN, Isaiah, (2004), Liberty, ed. Henry Hardy, Oxford, Oxford University Press. BERNAYS, Edward (2005), Propaganda, New York, Ig Publishing.

GOTTFRIED, Paul Edward (2002), Multiculturalism and the Politics of Guilt: Toward a Secular Theocracy, Columbia \& London, University of Missouri Press.

KIMBALL, Roger (1998), Tenured Radicals, Chicago, Elephant Paperbacks.

LASCH, Christopher (1996), The Revolt of the Elites and the Betrayal of Democracy, New York \& London, W. W.

Norton \& Company.

LÉVY, Élisabeth (2002), Les maîtres censeurs, Paris, Lattès.

LIPPMANN, Walter (1955), The Public Philosophy, New York, Mentor Books.

LIPPMANN, Walter (1997), Public Opinion, New York, Free Press Paperbacks.

MILL, John Stuart (1998), On Liberty and Other Essays, ed. John Gray, Oxford, Oxford University Press.

STRAUSS, Leo (1988), Persecution and the Art of Writing, Chicago \& London, The University of Chicago Press. 
(Página deixada propositadamente em branco) 


\section{OS IMPASSES SOBRE A LIBERDADE DE IMPRENSA NO PENSAMENTO UTILITARISTA}

\section{Carlos Camponez}

No presente artigo, propomo-nos reflectir acerca dos impasses sobre a liberdade de imprensa no pensamento utilitarista. Fá-lo-emos procurando confrontar os pensamentos de Jeremy Bentham, em «Sobre a liberdade de imprensa e de discussão pública» $(1821)^{47} \mathrm{e}$ em "Garantias contra o abuso do poder» (1822-1823), e de John Stuart Mill, em Sobre a Liberdade (1859). De acordo com o ponto de vista que sustentaremos aqui, a dissensão que consideramos existir entre estes dois pensadores utilitaristas representa um marco importante numa evolução que, por razóes não apenas filosóficas, foi distinguindo cada vez mais a função social de liberdade de imprensa da liberdade individual de expressão, embora sem nunca chegar a separá-las definitivamente.

\section{Sobre a Liberdade: a nova Areopagítica}

Na perspectiva da liberdade de expressão e da liberdade de imprensa, o livro de John Stuart Mill Sobre a Liberdade, publicado em 1859, representa o culminar de dois séculos de pensamento sobre um tema decisivo da história. Com efeito, estamos perante um texto que, em certa medida, é a reactualização, em termos modernos, da discussão iniciada por John Milton, em 1644, com a publicação de Areopagitica, e desenvolvida pelo pensamento iluminista acerca da liberdade individual, da liberdade de expressão e da liberdade de imprensa. Uma primeira leitura dos livros Areopagitica e Sobre a Liberdade não deixará de notar a semelhança de argumentos utilizados num e noutro texto. Este aspecto terá levado alguns comentadores de Mill - tanto admiradores como detractores - a referirem-se ao Sobre a Liberdade como a nova Areopagitica (O’Rourke, 2001: 145 e nota 5 na p. 205). De facto, o seu pensamento retoma muitos dos argumentos miltonianos sobre a liberdade de expressão, a liberdade de imprensa e o fim da censura prévia. Só para recordarmos alguns deles, podemo-nos referir à discussão pública como um modelo essencial de formação das opiniôes; ao reconhecimento do estatuto do erro como elemento inextricável da verdade e de reafirmação da própria verdade; à razáo como elemento fundamental de ligação do sujeito à verdade; enfim, à defesa da liberdade de expressão como uma dimensão intrínseca de realização da natureza humana.

Obviamente que a identificação destas semelhanças exigiria uma abordagem mais consentânea com uma leitura do pensamento dos autores, nomeadamente procurando en-

$47 \mathrm{Na}$ realidade, trata-se de quatro cartas abertas escritas às Cortes espanholas, em 1820, que deveriam ser traduzidas por M. Mora, chefe de redacção de El Constitucional, na esperança que seriam publicadas antes dos debates sobre o projecto-de-lei sobre a liberdade de expressão e de discussão pública. Porém, isso não chegou a acontecer porque as cartas acabaram por se extraviar, chegando ao conhecimento público apenas em 1821, depois de as leis, contra as quais estas cartas se dirigiam, terem sido aprovadas. 
tender se aquilo que hoje podemos ler no texto de Milton corresponde exactamente ao seu pensamento, há mais de três séculos e meio. Para além disso, como refere Kevin C. O’Rourke, a herança radical de John Stuart Mill permitiu-lhe ter uma identidade que ele próprio julgava ser completamente oposta à de Milton e que - nas suas palavras -, com todo o seu republicanismo, teria a alma de um fanático, de um déspota e de um tirano (Apud O'ROURKE, 2001: 159).

A discussão acerca do Sobre a Liberdade como uma nova Areopagitica não deve fazer-nos esquecer os elementos inovadores da abordagem de Mill. De facto, os argumentos miltonianos sobre a liberdade de pensar, a liberdade de escrever e a liberdade de publicar, bem como a defesa do fim da censura prévia sofreram uma importante reactualização no contexto do pensamento liberal do séc. XIX e do denominado segundo liberalismo. Como refere Pierre Manent, este «segundo liberalismo» tem por principal tarefa absorver o choque causado pelos acontecimentos e as ideias da Revoluçáo Francesa, bem como compreender essa aparente contradição que resultou do facto de as ideias liberais, durante o período revolucionário, terem sido geradoras de mais perseguição e opressão do que durante o período anterior, no final do Ancien Regime (Manent, 1987: 173). Segundo defendemos noutro texto (Camponez, 2010: cap. V), este é um elemento que perturba o pensamento liberal do século XIX e que não deixará de contribuir, de forma importante, para uma compreensão mais problematizadora da liberdade de expressão e da liberdade de imprensa, que até então eram vistas como o corolário uma da outra. Lentamente, em especial no velho continente, esta visão acabará por evoluir no sentido de distinguir estas duas realidades, quer no plano dos princípios, quer no plano do Direito.

\section{Bentham: a imprensa como um tribunal da opiniáo pública}

O conceito contemporâneo de imprensa como instrumento importante do escrutínio público, fundamental para as democracias contemporâneas, é em muito devedor do pensamento utilitarista, em particular de Jeremy Bentham. Nele, se fundam as concepçôes que inspiraram a visão da imprensa e dos jornalistas como quarto-poder ou os cães-de-guarda dos cidadãos face aos governos e à administração pública. A noção de quarto-poder e de cão-de-guarda das instituiçôes democráticas fez o seu caminho a partir da ideia central que Bentham atribuía à divulgação e circulação das informaçóes acerca da vida pública. Para o filósofo inglês, só o escrutínio público é capaz de limitar a tendência para os abusos inerentes ao exercício do poder sem controlo. Com efeito, Bentham tem uma opiniáo essencialmente negativa do poder, em particular dos seus detentores. Ele considera que os ministros do governo são pessoas que, à imagem do que fariam todas as outras no seu lugar, «aproveitarão todas as ocasióes para sacrificarem o interesse da comunidade aos seus interesses particulares» (Bentham, 2001ª :58-59). Para Bentham, o abuso do poder, mais do que uma questâo de ética política, resulta da própria natureza humana. Diz-nos ele a este propósito:

«(...) sendo a natureza humana o que é, qualquer pessoa a quem se dá um qualquer poder (...) está certamente em condiçôes de, nesse próprio dia, pensar sobre a forma de perpetuar todos os malefícios nunca anteriormente por ela ousados; e a menos que esteja limitada pelo medo do que o público possa pensar ou fazer, é provável que ela ponha em execuçáo os seus planos, a partir do dia seguinte» (Idem). 
Neste âmbito, a divulgação pública das questóes políticas desempenha um papel de vigilância e escrutínio do poder (Splichal, 2002: 59). Mais do que as reunióes públicas, essa função de controlo é desempenhada pela imprensa, equiparada a um tribunal oficioso, isto é, o tribunal da opinião pública. A imprensa entendida como o tribunal da opinião pública representa no pensamento de Bentham muito mais do que uma mera alegoria. No seu texto «Garantias contra o abuso do poder» (1822-1823), ele estabelece um claro paralelismo entre os tribunais oficiais e o papel atribuído à imprensa em Inglaterra. Esse papel seria o de 1) atender reclamaçôes e queixas; 2) ouvir as respostas da defesa; 3) ouvir, "arrancar», juntar e conservar os testemunhos; 4) ouvir, escutar ou ler os argumentos das partes envolvidas ou dos seus advogados; 5) formar uma opinião sobre os argumentos em presença, julgá-los e tirar deles as ilaçôes correspondentes para depois; 6) exprimi-los; 7) imprimi-los; 8) difundi-los; e, finalmente, 9) proceder de modo a que os julgamentos efectuados e as ilaçóes retiradas produzam efeito (Bentham, 2001 $:$ 148).

Para Bentham, fazem parte do tribunal de opinião todos quantos se interessam pelos assuntos públicos, entendidos como matérias que dizem respeito a cada um e a todos os membros pertencentes a uma comunidade. Este tribunal é pensado à luz e semelhança de uma comunidade composta por quatro tipos fundamentais de pessoas: os que apenas tomam a palavra; os que tomam a palavra e lêem; os que não só falam e lêem, mas também escrevem; e, finalmente, os que, fazendo tudo isto, também imprimem e publicam (Bentham, 2001 ${ }^{\mathrm{b}}$ : 145).

Esta comunidade está por sua vez organizada por vários sub-comités, os mais importantes dos quais são, por ordem de importância: os de «subintendência geral», constituídos pelos editores, chefes de redacção, colaboradores, leitores e clientes em geral; os da «administração judicial», compostos por pessoas que acompanham as questôes de interesse público e formam sobre eles uma opiniáo; e os religiosos, que agregam a comunidade de crentes, bem como os seus líderes.

Bentham defende a existência de um grande número de jornais, com uma circulação tanto mais vasta quanto possível, uma vez que eles são considerados o principal instrumento para o funcionamento da opinião pública. O jornal, melhor do que qualquer outra forma de imprensa (panfletos, livros, etc.), era considerado como o único meio capaz de garantir um acompanhamento regular dos acontecimentos (Bentham, 2001 ${ }^{\text {b: }}$ 130). Para além disso, no seu entender, nenhuma outra produção impressa poderia rivalizar com o jornal na forma de publicitação dos assuntos públicos, assumindo uma dimensão cívica e pedagógica incontornável:

«Abrindo o jornal, cada leitor vai à procura do tema que lhe interessa mais. Mas enquanto ele se dedica a esta busca, passam-lhe sob os olhos todo o tipo de assuntos. Pouco a pouco, o aspecto estranho e detestável destes outros temas esbate-se e o leitor familiariza-se com cada um deles. Mesmo supondo que ele deixa regularmente de lado os assuntos que de todo nâo lhe interessam e para os quais nem sequer olha, o seu interesse por aqueles a que não é totalmente indiferente desperta, apesar de tudo, a pouco e pouco» (Bentham, 2001 ${ }^{\mathrm{b}}$ : 132).

A importância da imprensa faz com que ela deva estar ao serviço da «maior felicidade da maioria», enquanto único princípio de acção social admissível (Bentham, 2001': 139). Esta concepção é em tudo compatível com a noção de quarto poder da imprensa, cuja expressão é atribuída a Edmund Burke quando se referia à galeria reservada aos jornalistas para assis- 
tirem aos debates do parlamento britânico (Splichal, 2002: 59). Mas o grande contributo desta visão foi permitir, no final do séc. XIX, a construção de uma ideologia acerca do jornalismo, visto como quarto poder ou como cão-de-guarda dos governos e da administração. Ela influenciou os próprios paradigmas de investigação e da teoria da comunicação, que legitimaram a ideologia profissional do jornalismo, com base na existência de funçóes «universais» que os media deveriam desempenhar na sociedade. Essa dimensáo escrutinadora e de serviço público impôs-se como poderoso conceito que estruturou o próprio jornalismo, a ponto de se constituir, nas palavras de Peter Braestrup, numa autêntica «teologia pública» dos jornalistas americanos (Apud Goodwin, 1993: 306).

Parece-nos, no entanto, que nâo podemos atribuir esta visão instrumental do jornalismo unicamente a Bentham. Autores como Stephen Ward referem que todas as formas de jornalismo, no séc. XVIII, contêm no seu seio um potencial de esclarecimento, informação e liberdade (Ward, 2004: 160), não sendo apenas uma forma de expressão individual por outros meios, escritos ou impressos.

No entanto, o investigador esloveno, Slavo Splichal, no confronto que faz sobre o pensamento de Bentham e Mill, sublinha a importância que uma certa visão utilitarista exerceu no final do séc. XVIII e durante o séc. XIX, ao ponto de marcar profundamente o próprio jornalismo moderno.

Este aspecto parece-nos relevante na medida em que, não obstante alguns princípios normativos já antes atribuídos à imprensa, a ênfase de um certo utilitarismo dado ao papel instrumental do jornal acabou por constituir uma dimensão relativamente nova, comparativamente ao pensamento iluminista acerca da liberdade de expressão e da liberdade de imprensa. Splichal chega mesmo a defender que a racionalidade e o papel da crítica que o pensamento iluminista atribuía à liberdade de escrever e de imprimir estão secundarizados e quase completamente ausentes da ideia de publicitação em Bentham (Splichal, 2002: 59). Em seu entender, a visão benthamiana sobre a função dos jornais como escrutinadores independentes do poder político e do Parlamento reduz as relaçóes de poder aos actores institucionalizados, directamente envolvidos no processo legislativo, negligenciando outros agentes de poder na sociedade, em particular, as pessoas comuns. Escreve ainda Splichal:

«[em Bentham] o aspecto referente ao debate racional tem apenas uma importância secundária; o carácter "crítico» da publicidade (e.g., no sentido de uma oposição ao governo) está quase ausente; e a ideia racionalista da liberdade humana não existe de todo» (Idem).

No entanto, não podemos deixar de notar que, como afirma Bentham, a publicitação surge como um conceito muito próximo do de opiniáo pública, ainda que não seja propriamente um sinónimo (Bentham, 2001를 108). Como vimos, a opinião pública funciona à maneira de um tribunal, onde o papel crítico não deixa de estar presente, embora aquilo com que Bentham parece estar preocupado seja operacionalizar uma certa ideia de imprensa e de jornalismo como instrumento que responda às exigências de uma opinião pública informada e actuante. De facto, como afirma no seu texto sobre a liberdade de imprensa e de expressão, a «sagesse aproxima-se mais da perfeição quando dispomos de meios gerais de informação (...) do que quando esses meios estão ausentes» (Bentham, $\left.2001^{\mathrm{a}}: 53\right)$. 


\section{O utilitarismo «iluminado» de Mill}

Esta concepção acerca da liberdade de expressão e do papel da imprensa é bastante diferente da de John Stuart Mill cujo pensamento, neste aspecto, parece estar mais na linha da tradição iluminista do que na da filosofia utilitarista de Bentham. O próprio Mill acaba por nos explicar a razão fundamental desta dissensão. Nas suas próprias palavras, Bentham concebe o homem como um ser destituído de capacidade de prosseguir, como um fim válido por si, uma acção desinteressada, razão pela qual conceitos como consciência, princípio, rectidão e dever resultam mais do amor-próprio do que de uma vontade de um sujeito moral. Num contexto em que toda e qualquer acção dos sujeitos esteja marcada pelo interesse pessoal, ou seja, na concepção utilitarista, a realização do seu próprio prazer, só é possível limitar a conduta individual por via do receio das sançóes, sejam elas provenientes da lei, da religião ou da opinião pública (Mill, 1999: 30). Essa é a razão pela qual a imprensa assume mais um carácter de vigilância dos sujeitos detentores do poder do que de um potencial crítico e de formação de uma racionalidade da vida pública, questáo que, no pensamento de Bentham, parece bem mais secundarizada do que na tradição iluminista e liberal.

A desconfiança em assentar um projecto social em princípios morais pode ajudar-nos a compreender a forte crítica que Bentham fez à Declaração dos Direitos do Homem e do Cidadão de 1791 e de 1795, considerando que ela traz a marca das paixóes egoístas e das paixôes hostis que, por mais necessárias que elas sejam à existência de cada indivíduo ou à sua segurança, são na realidade os grandes inimigos da paz pública.

A descrença de Bentham no carácter desinteressado e estritamente moral dos sujeitos leva-o a alimentar uma profunda desconfiança de princípio sobre o sentido das palavras ${ }^{48}$, chamando, nomeadamente, a atenção para as armadilhas que elas podem esconder. Perante tão radical posicionamento face aos princípios éticos e morais do ser humano e, por consequência, das sociedades, a questão que se coloca é pois a de se saber como viabilizar um projecto comum sem uma filosofia das leis, das instituiçóes e dos valores.

Como explica Mill, a filosofia de Bentham aplica-se mais propriamente à regulação dos bens materiais como condição para assegurar o bem-estar do maior número de pessoas, do que a um projecto moral emancipador dos sujeitos e das sociedades. Talvez também por isso, a forma que Bentham encontrou para melhor alcançar o desiderato de bem-estar tenha sido o do exercício do poder da maioria e do sufrágio universal, não se preocupando com algumas questôes qualitativas dessa realização.

Porém, John Stuart Mill parece ter uma visão mais complexa do bem-estar, distinguindo entre prazeres inferiores e superiores e entre fins secundários da moralidade - sobre os quais considera ser possível um consenso - e os fins últimos ou os fundamentos da moral, sobre os quais é mais difícil estabelecer acordos, exigindo também um saber mais profundo dos sujeitos implicados na discussão (Mill, 1999: 39).

Nestes aspectos, Mill distancia-se de Bentham: numa visão mais optimista sobre a capacidade da acçáo desinteressada dos sujeitos; na recusa de uma concepção redutora do

48 Exemplo disso é o comentário que Bentham faz a propósito da expressão «ordem pública» constante no art. $^{\circ} 10$ da Declaração de 1791: «A liberdade de publicaçáo, no que se refere às opiniōes, com ou sem excepção, seria muito conveniente que fosse estabelecida, mas que só o é de uma forma muito precária num artigo assim formulado. "Perturbar a ordem pública: o que quer isso dizer? Luís XVI não teria hesitado em admitir um artigo formulado nestes termos no seu código» [BENTHAM, 2007: 69]. 
princípio do bem-estar aos aspectos materiais ${ }^{49}$; e na rejeição da ideia de atribuir às maiorias o critério último do que esse bem-estar possa significar.

A forma como Mill vê a utilidade, no seu sentido mais amplo, «baseado nos interesses permanentes das pessoas enquanto seres em desenvolvimento» (Madeira, 2006: XIX), faz apelo à necessidade de um sistema crítico capaz de fazer evoluir o próprio conceito utilitarista de bem. Para que isso seja possível, torna-se necessário retomar alguns princípios que estavam na base da defesa da liberdade de expressão e da liberdade de imprensa, tal como foram sendo formulados por Milton e aprofundados pelos iluministas.

\section{Maioria, individualismo e liberdade}

O pensamento iluminista sublinha a livre circulação das ideias como um elemento fundamental de estruturação da opinião e da racionalidade públicas, sobre as quais assenta a legitimidade da soberania política. Rousseau chamou a essa racionalidade pública vontade geral, que se manifestaria através do exercício de uma democracia directa do povo, embora nunca se tivesse preocupado em pensar num modelo destinado a operacionalizar essa mesma vontade (Splichal, 2002: 90). Já em Kant, a livre circulação das ideias é uma condição indispensável do próprio uso público da razão. Este representa uma forma específica de comunicação deliberativa que implica um conhecimento dos processos de exercício político e de cidadania. Esta é a razão pela qual Kant atribui tanta importância à liberdade de escrever, considerando-a como o paladino ${ }^{50}$ da liberdade do povo.

Assim, se no pensamento utilitarista de Bentham a publicitação, na qual os jornais desempenham um papel crucial, tem uma função instrumental de vigilância e de limitação dos abusos do governo, em Kant o uso público da razão mais do que instrumento é o próprio procedimento que permite reconciliar política e legitimidade, ou seja, assumir a política de um ponto de vista moral (Splichal, 2002: 111-112). Em termos kantianos, isto significa que os procedimentos de divulgação pública das ideias e, em particular, da liberdade de imprensa, não representam apenas um meio, mas são, em si mesmo, um fim, enquanto conceito transcendental do direito público, baseado nos cidadãos, na dignidade e numa soberania moral.

O princípio de que qualquer tipo de interdição da divulgação das ideias constitui um entrave ao progresso é um conceito que inspirou o pensamento iluminista e que se reflectiu

49 Diz Mill a este respeito: «É indiscutível que um ser cujas capacidades de prazer são baixas tem uma maior possibilidade de vê-las inteiramente satisfeitas; e um ser superiormente dotado sentirá sempre que qualquer felicidade que possa procurar é imperfeita, tendo em conta a maneira como o mundo é constituído. Mas ele pode aprender a suportar as imperfeiçóes da sua felicidade, se são de todo em todo suportáveis; e elas não o farão invejar o ser que, na verdade, não tem consciência das imperfeiçôes, mas unicamente porque náo sente, de modo algum, o bem que essas imperfeiçóes limitam. É melhor ser um ser humano insatisfeito do que um porco satisfeito; um Sócrates insatisfeito do que um idiota satisfeito. E se o idiota ou o porco têm opinião diferente, é porque apenas conhecem o seu lado da questão. A outra parte da comparação conhece ambos os lados» [MILL, 2005: 54].

50 Uma expressão que encontramos em John Trenchard e Thomas Gordon, sob o pseudónimo de Cato. Na $15^{\text {a }}$ carta, de Fevereiro de 1720, [John TRENCHARD e Thomas GORDON, (1995), «Of freedom of speech: That the same is inseparable from public Liberty", in Cato's Letters - Or Essays on liberty, civil and religious, and other important subjects, vol. I, Indianapolis, Liberty Fund, p. 114] e numa das intervenções de Mirabeau, nos Estados Gerais, nas vésperas da Revolução Francesa [MIRABEAU, (1992), De la Liberté de la Presse - 1788, Caen, Centre de Philosophie Politique et Juridique de L’Université de Caen, p. 420]. 
na própria concepçáo sobre a liberdade de expressão e de imprensa. Essa concepção encontramo-la igualmente em John Stuart Mill que, na linha do pensamento iluminista, defende a ideia da liberdade intelectual como um domínio que não está sob a dependência dos outros e que náo deve ser objecto de qualquer interferência, nomeadamente - e na senda do que pensava também, a este propósito, Alexis de Tocqueville - do poder da maioria.

As questóes levantadas em torno do papel das maiorias na determinação da vontade colectiva são certamente um tema candente no pensamento de meados do séc. XIX e reflectem a inquietação acerca do clima de terror gerado durante a Revolução Francesa que, como referimos atrás, tanto preocupou o pensamento do denominado segundo liberalismo. A preocupação com este tema faz com que Mill faça avançar o debate relativamente aos iluministas. Como já aqui vimos, Kant considera a liberdade de escrever como o paladino da liberdade política dos povos. Mas Mill, sem pôr em causa este princípio, tem, no entanto, uma opiniāo bem mais ambivalente. Por um lado, ele vê na imprensa algo que pode actualizar a antiga ágora dos gregos. Mas, por outro lado, não deixa de considerar que os jornais representam a submissão dos indivíduos relativamente às massas (Splichal, 2002: 143). Para além disso, como refere Splichal, para Mill a liberdade de imprensa reconhecida aos jornais só em parte contribui para a disseminação de ideias que realmente interessam à sociedade e, nalguns casos, promovem mesmo a mediocridade em vez de a prevenir (Splichal, 2002: 144). Nesse sentido, ela não seria sequer fundamental para assegurar a liberdade individual, como se poderia provar com o caso de outros países europeus onde existiam leis mais restritivas do que as existentes na Inglaterra no domínio da imprensa, sem que isso impedisse a realização da autonomia dos sujeitos. Mais do que a liberdade de imprensa, tal como a entendemos hoje, o que está em causa é, pois, a possibilidade de realização do próprio projecto iluminista da razão pública e da liberdade dos sujeitos. Neste domínio, Mill, sem ser kantiano, parece bem mais próximo de Kant do que da corrente utilitarista onde ele próprio se inseria (Splichal, 2002: 131). Contrariamente ao que acontecia com Bentham, para Mill, a questão fundamental não reside apenas em assegurar a divulgação das ideias, como uma forma de controlo da administração pública, mas antes no modo de permitir melhores escolhas, através do reforço dos mecanismos de mediação da comunicação. Para além disso, ele não concorda totalmente com o papel que Bentham atribui à maioria, em particular no que se refere às incidências sobre as liberdades individuais. Enquanto Bentham está particularmente preocupado em limitar o poder político, visto como o poder de uns poucos sobre a vontade dos restantes, Mill analisa esta questão de uma forma muito mais alargada, não deixando de incluir a própria sociedade nas formas de tirania contra a liberdade individual (Mill, 1997: 13). Com efeito, o princípio da maioria continua a persistir numa forma de pensar o poder da sociedade subjugada aos interesses egoístas de classe (Mill, 1999: 39) - antes o poder de alguns, agora o poder da maioria - sem necessariamente contribuir decisivamente para o progresso geral da sociedade, entendido aqui num sentido amplo e enquanto um projecto inacabado, cuja evolução depende do processo crítico proporcionado pela liberdade de pensar, de falar e de escrever de cada um dos sujeitos (Mill, 1997: 21).

A visão crítica de Mill sobre o poder e a irracionalidade das maiorias levá-lo-ão a distanciar-se também da ideia de Bentham que atribuía aos jornais um papel decisivo para o controlo do poder. Como refere a este propósito Slavko Splichal, Mill considerava mesmo que a penny press, que constituiu um marco importante para a massificação e industrialização da imprensa, promovia a mediocridade, em vez de a prevenir (Splichal, 2002: 148). 
O olhar crítico sobre o papel das maiorias levá-lo-ão mesmo a defender a protecção das ideias minoritárias ao afirmar que se qualquer de «duas opiniôes tiver mais argumentos que a outra, para ser, não apenas tolerada, mas encorajada e apoiada, é esta que estará, numa determinada altura e num dado local, em minoria. Essa é a opiniáo que, de momento, representa os interesses descorados, o lado do bem-estar humano que corre o perigo de obter menos do que lhe é devido" (Mill, 1997: 52).

Esta problemática constitui um dos aspectos sensíveis da filosofia de Mill e que esbarra nessa sempre difícil tarefa de conseguir compatibilizar os objectivos gerais da sociedade com os projectos de realização da liberdade de cada um dos seus sujeitos. Este projecto é tanto mais sensível quanto ele é susceptível de pôr em causa o próprio projecto utilitarista, na medida em que, para Mill, a busca do prazer náo se mede apenas numa perspectiva quantitativa, mas também qualitativa. Neste sentido, o poder das maiorias em determinarem o bem-estar imediato pode ser entendido como uma ameaça a esse objectivo mais elevado de alcançar a excelência moral e cultural. A este propósito, John Skorupski defende que se Mill permaneceu "bem mais democrata" do que outros autores que viram também este problema, como Tocqueville e Jacob Burkhardt, ele não deixou de ter uma visão moderada sobre o potencial de realização da democracia, em termos mais imediatos, não abdicando, no entanto, de acreditar nas possibilidades de todos os seres humanos desenvolverem as suas faculdades superiores (Skorupski, 2003: 186).

Esta abordagem não é muito diferente daquela que o levou a defender, nos Princípios de Economia Política, a intervenção do Estado, limitando, assim, o laissez-faire, laissez-passer. Aí, Mill considera que o consumidor nem sempre é o melhor juiz da mercadoria, assim como a opinião dos ignorantes não pode ser considerada suficientemente competente em matéria de cultura. Deste modo, ele admite que existem aspectos da vida que não podem reger-se unicamente pelo critério da competência de escolha dos indivíduos e que há aspectos da vida social que não podem funcionar nos mesmos moldes da economia de mercado (Mill, 1943: 804-836).

Um dos exemplos apresentados é o caso da educação cuja utilidade não pode ser equiparada a um uso quotidiano dos produtos correntes de consumo e cuja necessidade é tanto menos sentida quanto maiores forem as carências dos seus utilizadores. Em situaçóes como estas, ou quando as pessoas não estão em condiçóes de julgar a favor do seu próprio interesse $e^{51}$, ou ainda em momentos em que o mercado apresenta distorçóes, o Estado deve poder intervir.

Este facto leva mesmo Slavo Splichal a defender que John Stuart Mill está longe de corresponder à ideia comummente aceite que atribui ao filósofo a responsabilidade da noção de «livre mercado das ideias», uma expressão que, aliás, não se encontra em nenhum dos seus textos e é contrária à defesa que faz da intervenção do Estado na vida económica e social.

Mill é um claro defensor da liberdade de imprensa e da liberdade de expressão, tendo sido detido pela distribuição de textos considerados contra a moral pública - em causa estava um texto sobre a adopção de métodos contraceptivos. Para além disso, bateu-se contra a prisão de Richard Carlisle e da sua família por causa da publicação de textos contra a Igreja e de artigos de Thomas Paine, outro autor perseguido pelas suas ideias sobre a política e a religião. No entanto, nem por isso ele deixa de pensar a imprensa como uma liberdade que implica também a liberdade dos outros e, nesse sentido, considera que ela está sujeita a algumas regras. Por isso, ele defendeu a necessidade de os limites à liberdade

$51 \mathrm{~J}$. S. Mill refere-se às crianças, às pessoas mentalmente inaptas e, ocasionalmente, às mulheres. 
estarem devidamente regulados pela lei, como de resto tentou defender seu pai, James Mill, em Inglaterra, ou, em França, Condorcet, de modo a não permitir a livre interpretação dos poderes político e judicial sobre o que pode ou não ser escrito e publicado ou o que deve ser considerado ofensivo da moral e da ordem pública. No entanto, o direito pode ser também visto tanto como uma defesa da liberdade dos sujeitos face ao poder despótico como ao poder das maiorias.

Com efeito, para Mill, a liberdade de imprensa e a liberdade de expressão continuam ao serviço da realização do projecto iluminista da racionalidade pública. Mas para que isso possa acontecer, é preciso que o ponto de vista de cada um dos seus sujeitos possa ser escutado e não se veja silenciado pela indiferença. É também nesta linha de pensamento que o vemos a defender que a liberdade de expressão esteja submetida a regras de discussão de acordo com princípios éticos bem definidos, nomeadamente evitando: a deturpaçáo deliberada das ideias; a omissão de factos, argumentos ou descrição enganosa da opiniáo do outro; o desrespeito das opinióes minoritárias; a estigmatizaçáo dos que pensam diferente; e o uso da linguagem insultuosa (Mill, 1997: 56 e ss).

Para Mill, estas regras - que devem presidir a toda a discussão, e que de alguma forma chamam a atenção para a necessidade de uma ética comunicativa da discussão pública destinam-se a proteger as opiniốes minoritárias perante o que ele considera ser a tendência de as maiorias se dotarem de vantagens injustas (Mill 1997, 57) no debate público. Assim, estamos a falar de regras entendidas como formas de defesa contra o sectarismo social e o silenciamento de uma crítica lúcida. Este argumento leva mesmo Kevin C. O’ Rourke a defender que a defesa da individualidade é a questão central do livro Sobre a Liberdade, mais do que a liberdade de expressão ou a própria ideia de verdade. Para o comentador de John Stuart Mill, este aspecto coloca-nos perante um tipo diferente de utilitarismo uma vez que, antes de ser um procedimento para permitir a expressão do bem-estar da maioria, a liberdade de expressão é um instrumento essencial para garantir a própria realização dos sujeitos (O’Rourke, 2001: 163).

\section{Conclusáo}

Apesar de ambos serem defensores da liberdade de imprensa e da liberdade de expressão, Bentham e Mill têm duas concepçôes bastante diferentes acerca da sua realização. Se para Bentham a imprensa constitui um elemento fundamental para o exercício do tribunal da opinião pública contra os abusos do poder, para Mill a liberdade de imprensa continua bastante ligada a uma forma de expressão - uma liberdade de expressão por outros meios -, enquanto garante da realização dos sujeitos e, dentro do espírito iluminista, enquanto reserva do espaço crítico do progresso das sociedades.

Estas duas dimensóes do pensamento utilitarista, aqui reduzido ao pensamento de Mill e Bentham, antecipam uma evolução maior que o jornalismo se prepara para conhecer nesta altura e que marcará o início do denominado jornalismo moderno. A transformação dos leitores de jornais em públicos, a industrialização da imprensa, o desenvolvimento dos meios de comunicação, a profissionalização do jornalismo e a criação dos profissionais da informação acentuarão a dimensão instrumental do jornal e do jornalismo ao serviço da causa pública da informação, em detrimento da sua função crítica.

Se o pensamento e os princípios utilitaristas de Bentham marcaram os pressupostos da liberdade de imprensa até à primeira metade do séc. XX, as noções de livre circulaçáo e de 
livre mercado das ideias impuseram-se, sobretudo, a partir da II Guerra Mundial. Mas o que restou dessa liberdade foi a sua versão essencialmente empresarial e mercantilizada dos conteúdos e da liberdade de iniciativa (Splichal, 2004) mas que, à sua maneira, não deixa de continuar a pensar nas audiências como instrumentos de realização de negócios, quer visando atingir os públicos, quer procurando responder aos objectivos das minorias, entendidas, agora, como nichos de mercado. Porém, quer num caso quer noutro, a componente crítica e o respeito da individualidade surgem fortemente secundarizados, transformando frequentemente o livre mercado das ideias num mercado livre de ideias. Por mais que Mill possa ser associado à realização desse ideal de livre mercado das ideias, nada estará mais distante do seu pensamento do que as consequências e as lógicas silenciadoras desse mercado.

\section{Bibliografia}

BENTHAM, Jeremy, (2007), «Déclaration des droits de l'homme», in: BINOCHE, Bertrand, e CLÉRO, JeanPierre, Bentham Contre les Droits de l'Homme, Paris, Presses Universitaires de France.

BENTHAM, Jeremy, $\left(2001^{\mathrm{a}}\right)$, «Sur la liberté de la presse et de la discussion publique», in: BENTHAM, Jeremy, Garanties Contre L'Abus de Pouvoir et Autres Écrits Sur la Liberté Politique, Paris, Editions Rue d'ULM.

BENTHAM, Jeremy, (2001b), "Garantie contre l'abus de pouvoir», in: BENTHAM, Jeremy, Garanties Contre L'Abus de Pouvoir et Autres Écrits Sur la Liberté Politique, Paris, Editions Rue d'ULM.

CAMPONEZ, Carlos, (2010), Fundamentos de Deontologia do Jornalismo - A auto-regulação frustrada dos jornalistas portugueses (1974-2007), Tese de Doutoramento defendida na Universidade de Coimbra.

GOODWIN, H. Eugene, (1993), Procura-se Ética no Jornalismo, Rio de Janeiro, Editorial Nórdica.

MADEIRA, Pedro, (2006), «Introdução», in: MILL, John Stuart, Sobre a Liberdade, Lisboa, Ediçôes 70.

MANENT, Pierre, (1987), Histoire Intellectuelle du Libéralisme, s.l. Calmann-Lévy.

MILL, John Stuart, (1999), "Bentham (1838)», in: AUDARD, Catherine, Anthologie Historique et Critique de l'Utilitarisme - L'utilitarisme victorien (1839-1903), vol. II., Paris, Presses Universitaires de France.

MILL, John Stuart, (1943), Principios de Economia Política - Con algunas de sus aplicaciones a la filosofia social, México, Fundo de Cultura Económica.

MILL, John Stuart, (1997), Sobre a Liberdade, Mem Martins, Europa-América.

MILL, John Stuart, (2005), Utilitarismo, Lisboa, Gradiva.

MIRABEAU, (1992), De la Liberté de la Presse - 1788, Caen, Centre de Philosophie Politique et Juridique de L'Université de Caen.

O'ROURKE, C. Kevin, (2001), John Stuart Mill and Freedom of Expression - The genesis of a theory, Londres, Nova Iorque, Routledge.

SPLICHAL, Slavko, (2004), "Why are the rights of media owners considered superior to the personal right to communicate?», Media Development, n. ${ }^{\circ}$, URL: http://www.waccglobal.org/es/20042-citizenship-identitymedia/508-Why-are-the-rights-of-media-owners-considered-superior-to-the-personal-right-to-communicate. html, (05/10/2009).

SPLICHAL, Slavko, (2002), Principles of Publicity and Press Freedom, Lanham, Boulder, Nova Iorque, Oxford, Rowman \& Littlefield Publishers.

SKORUPSKI, John, (2003), "John Stuart Mill», in: CONTE-SPERBER, Monique, Dicionário de Filosofia Moral, vol. 2, São Leopoldo, Unisinos.

TRENCHARD, John, e GORDON, Thomas, (1995), "Of freedom of speech: That the same is inseparable from public Liberty", in:TRENCHARD, John, e GORDON, Thomas, Cato's Letters - Or Essays on liberty, civil and religious, and other important subjects, vol. I, Indianapolis, Liberty Fund.

WARD, Stephen J. A., (2004), The Invention of Journalism Ethics - The path to objectivity and beyond, Montreal, Londres, Ithaca, McGill-Queen's University Press. 


\section{NotAS BIOGRÁFICAS DOS AUTORES}

\section{Alexandre Franco de Sá}

Alexandre Franco de Sá é Professor Auxiliar no Departamento de Filosofia, Comunicação e Informação da Faculdade de Letras da Universidade de Coimbra, sendo actualmente Director do Curso de Licenciatura em Filosofia. Tem publicado regularmente nas áreas da Ética, da Filosofia Política e da Fenomenologia e traduzido obras de autores como Johann Fichte, Martin Heidegger, Eric Voegelin, Ernst Jünger e Carl Schmitt. É actualmente Presidente da Associação de Professores de Filosofia. Página pessoal: http://sites.google.com/ site/alexandrefrancosa/

\section{Ana Teresa Peixinho}

Ana Teresa Peixinho é Professora Auxiliar da Faculdade de Letras da Universidade de Coimbra, onde, em 1996, concluiu o mestrado em Literatura Portuguesa Moderna, com a apresentação da dissertação $A$ Génese da Personagem Queirosiana em Prosas Bárbaras, publicada pela Editora Minerva em 2002. Doutorou-se em 2008, em Ciências da Comunicação, pela Faculdade de Letras da Universidade de Coimbra. Publicou pela INCM duas ediçóes críticas de obras de Eça de Queirós. Participou em diversos colóquios e congressos, com comunicaçóes no domínio dos estudos queirosianos, bem como no domínio da História da Imprensa e da Análise do Discurso. É investigadora do CEIS20.

\section{Carlos Camponez}

Carlos Camponez Professor Auxiliar da Faculdade de Letras da Universidade de Coimbra. Docente de Ética e Deontologia, Sócio-Economia dos Media e foi membro do Conselho Deontológico do Sindicato dos Jornalistas (2008-2010). Jornalista free-lance e ex-jornalista do Diário de Lisboa, A Capital, Público, Jornal de Leiria e Regiáo de Leiria. Acompanha de perto as questóes relacionadas com a imprensa regional, sobre a qual defendeu a tese de mestrado, e da deontologia e auto-regulação dos jornalistas, tema da sua tese de doutoramento.

\section{Diogo Pires Aurélio}

Professor de Filosofia Política na Universidade Nova de Lisboa e investigador do Instituto de Filosofia da Linguagem, responsável pela área de Ética e Filosofia Política. Coordena actualmente o projecto "Global Justice and International Terrorism», financiado pela FCT.

Publicou várias obras no domínio da Filosofia, entre as quais Um fio de nada, ensaio sobre a tolerância (1997, 2010), A vontade de sistema (1998), Imaginação e poder, estudo sobre a filosofia política de Espinosa (2000), Razão e Violência (2007), Representação Política (2009). Traduziu e prefaciou ediçôes de Maquiavel, O Príncipe (2008), Espinosa, Tratado Teológico-Politico (1988, 2003, 2004, 2008), Tratado Político (2008, 2009) e Richelieu, Testamento Político (2008). Prefaciou a edição portuguesa do livro de Jacques Rancière, $O$ ódio à democracia (2007).

Foi director da Radiodifusão Portuguesa, administrador da INCM, presidente da Comissão Nacional da UNESCO e Director da Biblioteca Nacional.

Recebeu, em 2009, o Prémio de Tradução Científica e Técnica da União Latina/FCT, pela tradução do Tratado Político, e uma menção honrosa pela tradução de $O$ Príncipe. 


\section{Jónatas Eduardo Mendes Machado}

Professor Associado da Faculdade de Direito da Universidade de Coimbra. Autor de várias obras jurídicas na área do direito público. Director Executivo do Centro de Direitos Humanos do Instituto «Ius Gentium Conimbrigae» da Faculdade de Direito da Universidade de Coimbra. Obteve o grau de Mestre com a dissertação "Liberdade Religiosa numa Comunidade Constitucional Inclusiva» e o grau de Doutor com uma dissertação intitulada "Liberdade de Expressão». Teve a oportunidade de participar nas efemérides dos 400 anos do nascimento de Roger Williams e de John Milton, por muitos considerados, respectivamente, o pai da liberdade religiosa e o pai da liberdade de expressáo.

\section{José Tomaz Castello Branco}

José Tomaz Castello Branco é doutorado Ciência Política e Relaçóes Internacionais, pela Universidade Católica Portuguesa. É Professor Auxiliar Convidado no Instituto de Estudos Políticos da UCP, onde lecciona Teoria Política Contemporânea, Regimes e Sistemas Políticos e História do Pensamento Político. As suas áreas de investigação, centradas no âmbito da teoria política contemporânea, incluem áreas distintas como as do pluralismo de valores, liberdade e tolerância, utopismo, terrorismo e pensamento político islâmico contemporâneo.

\section{Manuel Alegre}

Manuel Alegre fez da liberdade um dos temas principais da sua vida enquanto político, escritor e poeta. Nasceu em Águeda, em 1936, numa família de tradição liberal e republicana. Estudante de Direito em Coimbra, a sua tomada de posiçáo sobre a ditadura e a guerra colonial levam o regime de Salazar a chamá-lo para o serviço militar em 1961, sendo colocado nos Açores, onde tenta uma ocupação da ilha de S. Miguel, com Melo Antunes. Em 1962 é mobilizado para Angola, onde dirige uma tentativa pioneira de revolta militar. É preso pela PIDE em Luanda, em 1963. Um ano mais tarde, depois de um breve regresso a Coimbra, parte para o exílio, na Argélia, de onde só voltou em Maio de 1974. Autor de uma vasta e reconhecida produção poética, iniciada com Praça da Canção em 1965, Alegre faz da poesia uma arma de combate em prol da igualdade, da liberdade e da intervenção cívica. Na sua obra encontramos também vários romances e livros infantis. Foi Prémio Pessoa em 1999. A sua obra mais recente é de 2010: O miúdo que pregava pregos numa tábua.

\section{Maria João Silveirinha}

Maria João Silveirinha é doutorada em Ciências de Comunicação, pela Universidade Nova de Lisboa. É Professora Associada da Secção de Comunicação do Departamento de Filosofia, Comunicação e Informação da Faculdade de Letras da Universidade de Coimbra, onde lecciona matérias ligadas à comunicação, à investigação dos media e aos estudos de género. Os seus interesses de investigação centram-se no tema das relaçóes entre as identidades e a comunicação como medium das interacçôes sociais. É neste sentido que tem investigado particularmente os temas dos direitos comunicativos das mulheres. É autora de vários livros e artigos científicos neste domínio. 
(Página deixada propositadamente em branco) 
Série

Documentos

Imprensa da Universidade de Coimbra

Coimbra University Press

2010 